\title{
CHRONICLE OF EVENTS AND INCIDENTS RELATING TO ASIA WITH RELEVANCE TO INTERNATIONAL LAW
}

July 1996 - June $1997^{*}$

\author{
Ko Swan Sik ${ }^{*}$ \\ with contributions from KRIANGSAK KITTICHAISAREE (Bangkok)
}

\section{TABLE OF HEADINGS}

Air traffic and transport

Aliens

Arms sales and supplies

Asia-Pacific Economic Co-operation forum (APEC)

Association of South East Asian

Nations (ASEAN)

Asylum

Borders, border disputes and border incidents

Broadcasting

Civil war

Codification of international law

Continental shelf

Cultural matters and property

Customs

Diplomatic and consular immunity and inviolability

Diplomatic and consular relations

Disarmament and arms control

Dissidents

Divided states: China

Divided states: Korea

Economic co-operation and assistance

Embargo

Emergency aid

Environmental pollution and protection

Espionage

Extradition

Fauna and flora

Financial claims
Fisheries

Foreign investment

Hongkong

Human rights

Immigration

Immunities

Insurgents

Intellectual property

Inter-state relations: general aspects

(Non-)Interference

International economic relations and trade

Japan's military role

Joint development and joint ventures

Judicial assistance

Jurisdiction

Korean War

Labour

Litigation

Loans

Macao

Mercenaries

Migrant workers

Military alliances

Military co-operation

Minorities

Missile technology

Monetary matters

Nationality

Non-Aligned Movement (NAM)

Nuclear energy matters

* General Editor

Asian Yearbook of International Law, Volume 7 (Ko Swan Sik et al., eds.

- Kluwer Law International; printed in the Netherlands), pp. 391-492 
Oil and gas

Organization for Economic Co-operation and Development (OECD)

Rail traffic and transport

Recognition

Refugees

Regional security

Rivers

Sanctions

Sea and sea traffic

Social matters

South Asian Association for Regional

Co-operation (SAARC)

Specific territories within a state: East Timor
Specific territories within a state:

Kashmir

Specific territories within a state: Tibet

State succession

Taxation

Technology

Telecommunications

Territorial claims and disputes

Terrorism

Transit

United Nations (UN)

Unrecognized entities

Weapons

World Trade Organization (WTO)

World War II

\section{AIR TRAFFIC AND TRANSPORT}

\section{US-Asian 'open skies' talks}

Five Asian countries were involved in discussions with the US on the issue of 'open skies' in air traffic. Talks had resulted in agreements with Singapore (see infra), Taiwan and Brunei, and continued with South Korea and Malaysia.(IHT 26/27-1096,16-06-97) Other Asian countries, however, such as Japan, China, Thailand and Vietnam, had strong reservations, fearing that large US airlines would end up dominating the major routes across the Pacific. Japanese-US negotiations had been stalled since August 1996, but were to resume in early January 1997.

A US draft open-skies pact called for removal of restrictions on passenger and cargo flights and routes - including those flying beyond the countries concerned - as well as on charter arrangements, fares and code-sharing agreements.(JT 05 and 11-1296;IHT 21-01-97)

It appeared that the US stood to gain most from the agreements because US airlines can draw far more passengers from their huge domestic market than any of the Asian carriers can draw from theirs. Moreover, under the agreements restrictions on international services were abolished but foreign carriers were not allowed to operate within the domestic market of each party, while the US market accounted for about $\mathbf{3 0}$ percent by value of the global passenger market. It was said that countries which were willing to conclude open skies agreements with the US either had competitive airlines or gave priority to promoting tourism, business travel and air freight efficiency.(IHT 16-06-97)

\section{Japan-Russia aviation negotiations}

In contradistinction to other major countries Japan had not yet concluded a new civil aviation agreement with Russia after the collapse of the USSR, despite Russian willingness to lift the current restriction on the number of Japanese airlines' flights 
over Siberia. The reason was that Japan claimed that Russia had inherited all the treaties of the USSR.(JT 02-11-96)

\section{Opening of North Korean air space}

It was reported that North korea would open its air space in December 1996 for overflights by foreign carriers.(JT 13-11-96)

\section{Singapore-US landmark air agreement}

As the first Asian country, Singapore reached agreement with the US on the opening of aviation markets on 23 January 1997.(IHT 24-01-97) The open skies agreement which was signed on 8 April 1997 lifted all restrictions on the operations of both countries' airlines in terms of routing, frequency and capacity. The agreement also provided for so-called 7 th freedom traffic rights, allowing scheduled cargo flights from either country to use each other's airports as hubs for regional operations. Singapore Airlines operated a total of 39 passenger and cargo flights weekly to the US while seven US carriers operated a total of 49 passenger and cargo services on Singapore.(ST 09-04-97)

\section{ALIENS}

See also: Minorities

\section{Participation in local government}

For the first time a Japanese municipality, Kawasaki, in October 1996 offered the possibility to resident aliens to serve on a representative municipal panel designed to incorporate their views into the municipal administration.

Earlier in the year Kawasaki was the first Japanese city to scrap a Japanese nationality requirement for people applying for certain municipal jobs.(JT 10-10-96)

On 28 October 1996 the Tokyo Metropolitan Government, as the first Japanese local government to do so, unveiled a report demanding the state revise laws to give foreign residents suffrage (but not to be elected) in local elections. The report referred to a ruling of the Supreme Court according to which the Japanese constitution does not prohibit foreign residents from having suffrage in local elections.(JT 29-10-96)

\section{Easing of visa requirements}

Aiming at doubling the number of foreign visitors in the next ten years, the Japanese transport ministry had proposed to the foreign ministry that visa restrictions, particularly for Chinese, be eased. So far, Chinese were not granted tourist visas unless they had a Japanese sponsor. Visa applications from Chinese were subject to more strict regulations than any other nationality. It was believed that about 40,000 Chinese were residing in Japan illegally.(JT 17-10-96)

\section{Racist attacks on Singaporean military in Australia}

Since a debate had erupted in Australia in 1996 over Asian immigration in the country, members of the Singaporean armed forces on training in Queensland, Aus- 
tralia, had been the victims of numerous racist attacks. The incidents prompted complaints from Singapore and expressions of regret by the Australian government.(JT 31-10-96)

\section{Aliens as crew members of Japanese tuna boats}

It was reported that Japanese fishing boats for deep-sea tuna fishing were nearly 40 percent manned by foreign fishermen. Fourty percent is the legal limit in Japan for foreign crew members. The reason of the high percentage was said to be partly because of the much lower wages paid to the foreigners than those paid to Japanese fishermen.(JT 30-11-96)

\section{ARMS SALES AND SUPPLIES}

\section{North Korean supplies}

According to South Korean sources North Korea had exported some 400 Scud-B and Scud-C missiles to Middle East countries since the late 1980s. It was said that North Korea had also helped Iran and Syria build missile plants and sold them missile technologies.(JT 26-09-96)

\section{Development of South Korean submarine with Russian help}

Daewoo Heavy Industries was reported to develop South Korea's first middlesized submarine in co-operation with Russian technicians and with Russian technology.(JT 17-10-96)

\section{Russian-US competition in the supply of weapons to South Korea}

A second shipment of Russian military hardware started arriving in South Korea on 21 October 1996. It was part of a deal of August 1996 for the supply of $\$ 150$ million worth of equipment as partial payment for overdue loans and interest.(JT 23-1096)

Among the equipment supplied would be the very advanced SA-12 anti-aircraft missiles. During a visit to South Korea in early April 1997 the US defense secretary urged South Korea not to buy the SA-12, voicing concern about its 'inter-operability' with US-made aircraft in use in South Korea, warning that it would be a political and military mistake to accept Russia's offer instead of buying the US Patriot air defence missiles.(IHT 07-04-97)

\section{Russian submarine for Iran}

It was reported that Iran would soon receive a third submarine from Russia.(JT 28-11-96)

\section{Russian jet fighters for India}

India signed an agreement with Russia on 30 November 1996 for the purchase of dozens of Su-30MK jet fighters worth more than $\$ 1$ billion. The contract would call 
for long-term joint work in the field of aircraft building and development.(JT 02-1296;AsahiEN 06-12-96;FEER 12-12-96:15)

\section{Military spending in Asia}

At more than $\$ 9$ billion, Southeast Asian arms spending in 1995 was 22 percent of world sales,making the region the third largest weapons market after the US and Europe. Among the reasons offered are US withdrawal from the Philippines in 1992, the need for defence spending to be in line with overall economic growth and military modernization.(JT 03-12-96)

\section{China's purchase of two destroyers from Russia}

It was reported that China had purchased two 'Sovremenny'-class destroyers from Russia, which were to carry supersonic ship-to-ship missiles.(FEER 13-03-97:20)

\section{Thai plans to buy arms in China}

According to a Bangkok Post report, as a result of the visit by the Thai prime minister to China in early April 1997, China had offered the sale of arms at friendship prices which was favourably considered by Thailand. A Thai military delegation would head for China in July 1997 by way of follow-up.(ST 09-04-97)

\section{War materials for Taiwan}

It was reported in August 1996 that US and French aircraft manufacturers had coordinated the delivery times of fighter planes for Taiwan (see 3 AsYIL 347) in order to minimize further protests from China.

Under a 1982 Sino-US communique calling for a reduction in quality and quantity of arms sold by the US to Taiwan, the US had agreed to stop selling advanced weapons to Taiwan. Nevertheless the US granted a Taiwanese request in 1992 to sell 150 F-16s, the first two of which were delivered in April 1997.(FEER 15-08-96 p.12;IHT 16-04,17-04-97)

Taiwan started deploying an initial batch of newly arrived US Patriot missile systems in early 1997. It had ordered 200 sets of missiles and launchers.(IHT 24-02-97)

China warned France in December 1996 that it would be 'resolutely opposed' to new French weapons sales to Taiwan and would treat such sales as an assault on its sovereignty. The Chinese spokesman recalled that "France has made a clear commitment in the January 12, 1994 joint communique that it would not sell weapons to Taiwan".(IHT 11-12-96) Five French-made Mirage fighter planes arrived in Taiwan on 5 May 1997.(FEER 15-05-97:15)

\section{Chinese arms sales to Iran}

When asked about Chinese sales of anti-ship missiles to Iran, the spokesman of the Chinese foreign ministry said: "Regarding the transfer of conventional weapons, including missiles, China has adopted a long-standing attitude of prudence and responsibility". He said that any sale should not harm the peace, security and stability of a region. It should strengthen the defence of the country involved but not exceed its needs. China generally notified the UN of exports of conventional weapons.(IHT 0406-97) 


\section{ASIA-PACIFIC ECONOMIC CO-OPERATION FORUM (APEC)}

\section{Membership}

One of the topics to be discussed at the 1997 APEC summit meeting was the question of the existing three-year moratorium on membership that would end in 1996. The industrialized members fear that expanded membership could cripple APE$C$ 's trade and investment liberalization drive (for which the moratorium was introduced), as APEC operates on consensus. Less developed members, however, wanted the forum to be open to the rest of the world. The following eleven countries had applied for participation in APEC: India, Macao, Mongolia, Pakistan, Peru, Russia, Colombia, Sri Lanka, Vietnam, Panama and Ecuador.(JT 19-10-96;AsahiEN 20-1196)

\section{Investment rules}

It was reported that Japan would try to get a stronger regional commitment to freer investment at the APEC meeting in November 1996 at Manila, as a support for the industrialized countries' effort to achieve global investment rules at the first ministerial meeting of the WTO which was due a month later. Specifically, Japan wanted to have the current non-binding principles of APEC on investment liberalization reinforced with additions such as a stand-still clause which would prevent additional restrictions from being introduced, or a roll-back clause stipulating the gradual removal of barriers. However, there would be strong opposition from Asian developing countries, Malaysia in particular.(JT 19-11-96)

\section{The 1996 Manila meeting}

It was reported since before the meeting took place that renewed emphasis would be laid on the original issues of economic and technical co-operation rather than on trade and investment liberalization. One of the reasons was that amid global economic slowdowns the developing member countries countered growing criticism that liberalization benefits mostly the multinational companies at the expense of local enterprises and workers. It was said that economic and technical co-operation had been overlooked since 1993, when the group embarked on a trade and investment liberalization program initiated by the US.

Industrialized members, on the other hand, could fear that the forum might turn into another organization to funnel aid to developing countries, and a fresh focus on economic and technical development may then widen the rift between industrialized and developing members.(AsahiEN 21-11-96)

The resulting "Declaration on an APEC Framework for Strengthening Economic Cooperation and Development", adopted on 23 November 1996, underlined sustainable and equitable growth as well as the narrowing of economic disparities among the members as main goals of the region's economic and technical co-operation.(IHT 03-12-96;JT 24-11-96) 
Proposed elimination of tariffs for computers and other information technology products

The US had proposed that the Manila meeting of APEC decide on elimination of the tariffs by 2000 (Information Technology Agreement, ITA), in order to press for further steps at the subsequent WTO conference in December 1996. The proposal was endorsed by Japan but rejected by the developing member countries (particularly China, Malaysia, Chile, and Thailand) because the range of products favoured the developed countries. The US accounted for about $60 \%$ of the $\$ 1.8$ trillion generated annually by the computer industry.

The Joint Declaration finally called for "the conclusion of an information technology agreement by the WTO ministerial conference that would substantially eliminate tariffs by the year 2000 , recognizing the need for flexibility as negotiations in Geneva proceed”.(IHT 23/24 and 26-11-96;JT 24-11-96;FEER 05-12-96:18)

\section{APEC Business Advisory Council}

The Council, consisting of members of the business community, was set up by APEC in 1996 to advise APEC on business matters.(JT 26-11-96)

\section{ASSOCIATION OF SOUTH EAST ASIAN NATIONS (ASEAN)}

See also: Dissidents, Inter-state relations (Myanmar, Japan-Southeast Asia), Regional security

\section{China as dialogue partner}

The ASEAN ministerial conference in July 1996 decided to grant the position of 'dialogue partner' to China, putting it on a par with the US, Japan, Australia, New Zealand, Canada and South Korea. As such it would take part in meetings of senior officials (SOM).(IHT 25-11-96;FEER 11-07-96)

At the dialogue meeting of April 1997 held at Huang Shan, China for the first time agreed to talk about the contrasting territorial claims in the South China Sea in a multilateral context.(FEER 08-05-97:15)

\section{Myanmar membership}

ASEAN decided, at its annual foreign ministers conference, to admit Myanmar as an observer on 20 July 1996 despite pressure from the US, the EU, Australia, Canada and Western human rights advocates to take a tougher stand.(IHT 20/21 and 23-07-96) The Indonesian foreign minister who chaired the meeting said that ASEAN's approach had "always been non-interference in the internal affairs of countries, and this will continue to be our line".(IHT 20/21-07-96) Myanmar had attended the previous foreign ministers conference as guest of the host country (6 AsYIL 344).

The ASEAN foreign ministers agreed at their meeting in July 1996 that Myanmar should not yet be admitted as a member in 1997 as it would need more time to prepare to take part in ASEAN's activities. In late August 1996 Myanmar officially applied for full membership in 1997.(JT 30-09-96;FEER 11-07-96:36) Vietnam said on 10 October 1996 that rejecting Myanmar's bid for full entry would be tantamount to meddling in its domestic affairs.(AsahiEN 11-10-96) The same month the Philippine 
president said that ASEAN could review its constructive engagement policy with Myanmar, while the Thai foreign minister said that Myanmar should bring in democracy before joining ASEAN. In November the Singapore prime minister said he did not think Myanmar was ready for full membership on economic grounds. On the other hand it was believed that Indonesia and Malaysia were in favour of quickly admitting Myanmar, perhaps in 1997, along with Laos and Cambodia. Finally the new Thai prime minister pledged on 26 November 1996 to visit Myanmar and try to persuade it to heed demands to respect human rights and democracy.(JT 28-11-96)

The ASEAN (first) informal summit on 30 November 1996, which Myanmar attended as a guest of the host country (Indonesia), decided to admit Myanmar as a full member simultaneously with Cambodia and Laos, but deferred the decision on the timing. ASEAN had already decided earlier to accept Myanmar by the end of the century.(IHT 02-12-96;JT 01-12-96;FEER 05-12-96:15) In January 1997 all member states were agreed that Myanmar would be admitted as a member in 1997. A decision to this effect was taken unanimously and without reservations by a ASEAN foreign ministers meeting on 31 May 1997 . The admission would officially take place at the annual meeting foreign ministers meeting in July 1997. As to the US and EU objections ASEAN maintained that a country's domestic policies are not a criterion for UN membership and nor should they be for ASEAN membership. The Malaysian foreign minister tried to limit the scope of the dispute by raising the idea of not assigning 'dialogue partners' to the new members.

Membership for Myanmar could disrupt the projected second summit of Asian and European heads of government (see 6 AsYIL 401) in London in 1998. Leaders of the Myanmar military government were banned from visiting Europe under visa restrictions imposed as part of a package of sanctions imposed by the EU in 1996 as a protest against a crackdown on the opposition in Myanmar. However, membership in ASEAN did not confer an automatic right to join the Europe-Asia summit.(IHT 25/26-01,02-06-97;FEER 12-06-97:14)

\section{Informal summit meetings}

It was decided at the summit meeting at Bangkok in 1995 that, while the heads of state and government meet every three years at a formal summit meeting, informal meetings would be held in each of the intervening years. The first such informal summit meeting was held in Jakarta, on 30 November 1996.(JT 01-12-96;FEER 1212-96:18)

\section{ASEAN-India consultations}

In accordance with the ASEAN system of layered regular consultation with nonmember states, ASEAN and India started consultations on the level of Joint Cooperation Committee (JCC), the first meeting of which was held in November 1996. There had already been consultations in the context of Senior Officers Meetings (SOM). JCC meetings involve higher level officials than SOM meetings.(ASEAN Update Nov./ Dec.1996) 


\section{Protocol on Dispute Settlement Mechanism}

The ASEAN economic ministers signed a DSM Protocol on 20 November 1996 in Manila. It is patterned after the WTO Dispute Settlement Understanding and is to apply to all past and future ASEAN economic agreements.(ASEAN Update Nov./ Dec.1996)

\section{ASEAN-EU and the issue of East Timor}

In 1992 the first EU attempt to conclude an ambitious trade and economic cooperation agreement with ASEAN ran into fierce opposition from Portugal which insisted that ties with ASEAN could only be upgraded when Indonesia made concessions over East Timor (see 3 AsYIL 349) A similar initiative by the EU Commission in July 1996 was threatened by the same danger, leading to the idea of an alternative, less formal, 'ministerial declaration' on future co-operation and the continuation of EU-ASEAN relations on the basis of a 1980 treaty. This in spite of a new Euro-Asean 'active partnership' drawn up at the time.(FEER 18-07-96:22,19-12-96:26)

At the ASEAN-EU ministerial meeting of 13-14 February 1997 at Singapore, ASEAN decided, at the request of Indonesia, to reject a discussion of the issue of East Timor. The Indonesian position was that the issue should be discussed under UN auspices and should be brought up in bilateral talks with Portugal.(IHT 04-02-97) The compromise reached was to issue a joint declaration highlighting plans for closer cooperation with separate protocols to be negotiated and signed on specific areas identified for fast-track treatment. In contrast to treaties, under EU rules protocols do not require unanimous consent but merely a qualified majority.(IHT 04-02-97;FEER 1302-97:21,27-02-97:22)

\section{The ASEAN Free Trade Area and obligations of new members}

It was agreed in connection with the admission of Myanmar, Cambodia and Laos as members of ASEAN, that they would be given 10 years from January 1998 to comply with the tariff-reduction schedule mandated by AFTA, while the other members, except Vietnam, are obliged to lower tariffs on $98 \%$ of their traded goods to below $5 \%$ before 2003 . Vietnam, which joined ASEAN in mid-1995, was given time until 2006.(FEER 12-06-97:15)

\section{ASYLUM}

\section{Denial of diplomatic asylum}

On 16 October three East Timorese men broke into the French embassy in Jakarta and asked for political asylum in Portugal, but they were evicted from the premises.(JT 17-10-96; AsahiEN 17-10-96)

\section{Indonesian asylum-seekers in Malaysia}

Sixteen Indonesians, allegedly from Aceh (North Sumatra) were detained in Kuala Lumpur when they tried to break into a number of Western embassies, apparently to seek political asylum.(IHT 26-12-96) 
BORDERS, BORDER DISPUTES AND BORDER INCIDENTS

See also: Inter-state relations (China-India, China-Russia)

\section{Reduction of Sino-Russian border troops}

Following the agreement of April 1996 on reducing military tensions along China's borders with Russia, Kazakhstan, Kyrgyzstan and Tajikistan (6 AsYIL 347), agreement was reached in December 1996 between China and Russia on cutting troop levels along their long $(4,000 \mathrm{~km}$.) border.

In 1991 a basic agreement on border demarcation was concluded.(JT 20-1196;AsahiEN 20-11-96;IHT 13-01-97) Under this agreement some 1,500 hectares of disputed territory, mainly in the triangle between Russia, China and (North) Korea along the Tuman (Tumangan) River would be handed over to China in due time. This would give China access to the Sea of Japan. The Chinese plan to build the port of Tumangan on that site. Shortly before the visit by the Chinese president to Moscow in spring 1997 it was reported that part of the Russian establishment was opposed to the idea of transfer of the territory.(AsT 09-04-97) Fears that a piece of land containing the graves of Russian soldiers would be included were allayed by drawing the border in such a way that the graves would remain Russian territory.

On the occasion of the Sino-Russian summit meeting in April 1997 the presidents of China, Russia, Kazakhstan, Kirgyzstan and Tajikistan signed another agreement on the reduction of border forces by way of follow-up of the 1996 agreement referred to above.(FEER 08-05-97:16) The new agreement fixed ceilings on the number of regular troops (in contradistinction to border guards or strategic forces) and weapons within a 100-kilometre zone along the former Sino-Soviet border, and on mutual information about troop movements in their border regions.(IHT 24-04,25-04-97;FEER 08-05-97:16)

\section{Sino-Indian agreement to prevent armed conflict on their common frontier}

Among the agreements concluded by China and India on the occasion of the Chinese president's visit to India in late November 1996 was an agreement on confidencebuilding measures to minimize the possibility of armed conflict at their borders. The agreement followed a 1993 agreement (4 AsYIL 417) on easing tension along their mutual border, and includes a mutual pledge not to attack each other across the disputed Himalayan border. The accord stated: "Neither side shall use its military capability against the other side", and added that no armed forces along the border "shall be used to attack the other side or engage in military activities that threaten the other side or undermine peace, tranquility and stability in the India-China border areas".

Besides general agreement was reached to pull back troops from the area, being a logical consequence of the above pledge. However, there was no specification on the numbers, nor how far the withdrawal would be and when it would take place. Disagreements about the exact location of the 'line of actual control' were yet to be resolved before the details on troop movements could be negotiated.(IHT 30-11/01-1296) 


\section{Myanmar - Thai border incidents}

Since late January 1997, members of the pro-government Democratic Karen Buddhist Army guerrilla group crossed the Myanmar-Thai border and attacked camps housing Karen refugees in Thai territory. The Thai army commander said: "As a matter of principle we have to protest to the Burmese [sic] government when our border is infringed by troops from Burma [sic], or any other country".(IHT 04/05-01,1102-97)

Observers saw three reasons for the attacks. First, they aimed at pressuring the Karens (Karen National Union) into accepting a cease-fire with the government, as had 15 other rebel forces. Second, the Myanmar government hoped the Thai government would be tired of housing the refugees and repatriate them to Myanmar. Third, the attacks were aimed at a meeting of ethnic minority groups from an area where the Myanmar government's efforts to draw up a new constitution were rejected.(FEER 13-02-97:25)

Later, in February 1997, Myanmar government troops, fighting Karen National Union insurgents, and Thai forces several times exchanged fire along the border. The Myanmar actions resulted in nearly 15,000 refugees entering Thailand since 11 February.(IHT 22/23-02,01/02-3-97)

While Thailand and Myanmar may be considered to be some kind of historical adversaries, a relative peace had been maintained at the 2,500 kilometre land border by the buffer of a string of ethnic insurgencies in Myanmar. It is said that Thailand has never felt the need for definitive borders, as porous borders diffuse conflicts and generate local revenue from trade. In fact only 58 kilometre land border with Myanmar has been formally determined.

However, the existing situation seemed on the point of disappearing as a consequence of the settlements reached by the Myanmar government with various insurgent movements and its efforts to crush the KNU.(FEER 06-03-97:34)

\section{Closure of Malaysia-Indonesia border in Borneo}

Malaysia closed part of its border with Indonesia on the island of Borneo after recent ethnic riots on the Indonesian side. The riots took place in the Indonesian province of West Kalimantan which borders the Malaysian state of Sarawak. The border closure stranded hundreds of Indonesians working in Sarawak.(IHT 04-0297;FEER 13-02-97:13)

\section{BROADCASTING}

\section{Radio Free Asia}

Radio Free Asia, originally called Radio Free China, and later renamed Asia Pacific Network (APN), was re-created in the US in response to the US International Broadcasting Act 1994. This Act was the result of an initiative of US senator BIDEN in 1991 to set up a surrogate broadcasting service to China, North Korea, Vietnam, Laos, Cambodia and Myanmar, aiming at influencing and combating communism and authoritarian regimes. The original Radio Free Asia, a product and tool of the Cold 
War era, began broadcasting to China in 1951 but was discontinued during the Eisenhower administration due to radical budget cutting.

US and APN officials approached and negotiated with several Southeast Asian and former Soviet republics to transmit the APN programs from their territory. In the case of Thailand and the Philippines permission was asked to use the local transmitters of the Voice of America for APN broadcasts, arguing that the existing agreements for the Voice of America transmitters in fact allowed these transmitters to be used by APN even without informing the host governments. Both countries, however, refused to give in to the US requests. Thailand said it would not allow the operation of a radio service that could interfere in the affairs of a third country or affect Thailand's relationships with its neighbouring countries. It emphasized its sovereign right to prevent and ban others from using its territory to attack a third country. China as well as Vietnam expressed gratitude to Thailand for its refusal.(FEER 12-09-96:13; JT 27-0996)

Chinese criticism of the radio broadcaster was rejected by the US State Department, which defended it by saying that the "Chinese people ought to have access to information about economics, about politics, about Western culture and ideas".(Daily Yomiuri 10-10-96)

\section{'Democratic Voice of Burma'}

In November 1996 the German government gave its permission to the Norwaybased radio station 'Democratic Voice of Burma' to broadcast from Germany, using the services of the German telecommunications company Deutsche Telekom. It thus reversed its previous policy, enabling the station to improve the reception of its transmissions to Myanmar. The German foreign minister argued that he could find "no reason in international law" to forbid the co-operation between German Telecom and the DVB, provided the latter would not promote violence or revolution from German soil.

The DVB was established in Oslo in 1992 and is the mouthpiece of the self-styled Burmese government-in-exile, the "National Coalition Government of the Union of Burma".

Among the European states Germany used to be the biggest source of development aid for Myanmar and to be most moderate in its attitude toward Myanmar.(FEER 0512-96:30)

CIVIL WAR

See also: Inter-state relations (Attitude toward Afghanistan), United Nations

\section{Afghanistan}

It was reported that the government of BURHANUDDIN RABBANI had reached a cease-fire agreement with the opposition Supreme Coordination Council alliance led by the National Islamic Movement under RASHID DUSTAM. The two sides had begun fighting in January 1994 (see 4 AsYIL 422).(IHT 13-08-96)

The Taleban rejected the government's offer to negotiate, accusing the president of illegally keeping to his position, because he was supposed to have resigned in 1995 
under a UN accord (see 5 AsYIL 397). On 11 September 1996 the Taleban militia captured the main eastern town of Jalalabad. Kunar, the last pro-government province on the eastern border, was captured later in the month.

The neighbouring countries, Pakistan, Iran, Uzbekistan, India and Russia, each had chosen favourites in the fighting because of their interest in opening trade routes through land-locked Afghanistan and installing a friendly government in the traditional buffer state.

The Afghan government asked the UN Security Council to meet on the crisis and accused Pakistan of supporting the Taleban. The Security Council on 26 September called upon the parties to stop fighting, agree on a cease-fire and enter into negotiations to find a political solution to the conflict.

Ignoring the UN call, the Taleban militia captured the capital Kabul on 27 September 1996, two years after their formation. Government control was taken by a sixman ruling council (Shura). The Taleban executed the former president NAJIBULLAH and pursued the forces of the ousted president RABBANI into the north, saying they would hold war crimes trials for members of the ousted government. The movement called on the international community to recognize it as the government of the Islamic state of Afghanistan.

Pakistan announced it would dispatch officials for talks in Kabul. A foreign ministry official said Pakistan did not need to extend formal recognition to the Taleban government: "We recognize states, not governments, and we will deal with whatever government is in power." On the other hand, the Pakistan foreign minister was quoted as saying that Pakistan had always recognized the Kabul regime as the de facto government of Afghanistan. Later Pakistan was, after all, the first state to extend recognition to the Taleban government on 25 May 1997, followed by Saudi Arabia on 26 May 1997.

The US expressed hope that the Taleban would move toward national reconciliation, holding out the possibility of establishing diplomatic ties.(IHT 12,16,23,28/29 and 30-09-96,01-10-96,26 and 27-05-97; JT 27 and 29-09-96,01-10-96;AsahiEN 28-09-96)

At a news conference after the capture of Kabul, a senior official of the provisional government ruled out backing from the new government for international terrorism and said that the Taleban would not seek to spread its fundamentalist creed to other Muslim countries.(IHT 02-10-96)

The developments in Afghanistan led to the convening of an emergency summit meeting of Uzbekistan, Tajikistan, Kyrgyzstan, Kazakhstan and Russia on 4 October 1996. The meeting would focus on regional fears that the Taleban victory could have repercussions in the neighbouring Muslim republics.(AsahiEN 04-10-96)

After a cease-fire agreement between the BURHANUDDIN RABBANI government and the opposition 'Supreme Coordination Council' alliance led by the National Islamic Movement under ABDUL RASHID DUSTAM in August 1996 (IHT 13-08-96), an alliance emerged in October 1996 between the (ethnic Tajik) military chief of the ousted government, AHMAD SHAH MASOOD, the (ethnic Uzbek) DUSTAM, and ABDUL KARIM KHALILY, leader of the Shiite Muslim Hezb-i-Wahdat faction. Under it DuSTAM agreed to recognize the deposed RABBANI government. It was reported that the factions had created a 'Council for the defence of the motherland'. (JT 10-10-96;MainichiDN 12-10-96;AsahiEN 16-10-96;IHT 17-10-96) 
Later in the month the Pakistan government tried to broker a cease-fire between the parties. The offer was accepted in principle, but both parties set conditions that could not be met. The UN Security Council adopted resolution 1076(1996), drafted by Russia, calling for a cease-fire and political negotiations and calling for states to refrain from interfering in the conflict and stop supplying arms. As a result of efforts by the UN special envoy the two parties met and entered discussions in Islamabad on 7 November 1996 and again in January 1997.(IHT 21,22 and 23-10-96,08-11-96,14,1501-97)

Iran was being accused by the Taleban of interference in Afghan affairs by allegedly sheltering anti-Taleban troops and supplying them with weapons.(IHT 06-11-96) Although Iran tried to maintain good relations and in January 1997 offered to host peace talks (IHT 20-01-97) the Taleban government ordered Iran on 2 June 1997 to shut its embassy in Kabul and to evacuate its nationals within 48 hours, accusing it of "destroying peace and stability in the country".(IHT 03-06-97) Iran later restricted the flow of goods across its border into Afghanistan.(IHT 09-06-97)

In May 1997 an uprising broke out, under General ABDUL MALIK (MALIK PAHLAWAN?), against General DUSTAM, in the north of the country which was still controlled by the coalition opposing the Taleban.(IHT 21-05-97) The mutineers defected to the Taleban and General DUSTAM fled the country to Turkey. Thereupon the Taleban captured the northern town of Mazar-i-Sharif on 25 May, practically ending the civil war and uniting Afghanistan for the first time in two decades.

[The Taleban victory re-established dominance of Pashtuns, the country's largest ethnic group, and of the southern province of Kandahar. A Pashtun monarchy from Kandahar ruled the country for more than a century until 1973]

After a few days, however, the Taleban was again resisted, particularly by the Uzbek faction (under MALIK PAHLAWAN), and ethnic Hazaras who are predominantly Shiite, resulting in a change of control over Mazar-i-Sharif. Shortly afterwards it was reported that the Taleban had offered its opponents control of the northern part of the country as part of a peace plan that included a sort of federation.(IHT 26-05,27-05,0206,03-06,06-06-97;FEER 12-06-97:24)

\section{Tajikistan}

The UN Security Council renewed the mandate of the UN Mission of Observers in Tajikistan (UNMOT) subject to the condition that the 1994 Tehran Agreement on the cessation of hostilities remained in force (see 5 AsYIL 396) and that the parties demonstrate their commitment to a cease fire, national reconciliation and promotion of democracy.(JT 15-12-96)

On 23 December 1996 the parties in the 4-year civil war (the government and the United Tajik Opposition - UTO) and a UN envoy signed two key accords in Moscow. It was said that this was at least partly the result of pressure by Russia, which had become concerned of the progress made by the Taleban forces in Afghanistan in their push to the north and the consequent new importance of a Tajik buffer zone.

The accords regulate, inter alia, the powers and functions of a new national reconciliation commission. The two sides undertook to complete negotiations for a permanent peace settlement by July 1, 1997. These negotiations started in Tehran on 6 January 1997. In early March the parties agreed to merge their military forces by July 
1998. The next step would be the signing of a protocol on political questions.(IHT 24/25-12-96;FEER 16-01-97:13,27-03-97:24)

\section{CODIFICATION OF INTERNATIONAL LAW}

\section{The state of the codification process within the UN system}

In its resolution 50/45 the UN General Assembly decided that comments should be invited on the matter. In its reply of 29 August 1996 Japan said it did not share the view that further codification work is unnecessary:

"International law remains indefinite and underdeveloped in various areas, and even in those areas in which codification has taken place and legislative treaties have been adopted, practice is constantly changing and difficulties arise which make it necessary to address matters afresh."

As to the interaction between the Sixth Committee and the International Law Commission, Japan was of the opinion that the process should be one in which the two organs together select topics in response to real and current needs of the international community.

The Japanese reply also noted that the ILC might be asked to review the state practice in connection with previously codified matters, e.g. the law of treaties and the law on diplomatic and consular relations. It might also make efforts to identify areas such as the environment in which laws are being developed sector by sector or regionally and bilaterally, involving a risk of fragmentation and inconsistency. (UNdoc. A/51/365)

\section{CONTINENTAL SHELF}

\section{Sino-Japanese continental shelf}

According to Japanese government reports Chinese drilling vessels were believed to have succeeded in February 1996 in test-drilling for oil in the continental shelf east of the midpoint in the East China Sea between Japanese and Chinese parts of the continental shelf.(JT 02-11-96)

\section{CULTURAL MATTERS AND PROPERTY}

\section{Thai cultural agreements}

It was reported in July 1996 that Myanmar had agreed in principle to a Thai initiative to conclude a cultural agreement. Thailand was to sign another cultural agreement with Vietnam on 8 August 1996.(FEER 18-07-96:12) 


\section{Return of stolen Cambodian artifacts}

On 23 September 1996, the Fine Arts Department of Thailand returned to the Cambodian government, through the Cambodian ambassador to Thailand, 14 stone artifacts from the Angkor era believed to have been stolen from Cambodia and subsequently seized by the Thai police from an antique shop in Thailand in 1990. The Cambodian government had not produced any proof of ownership over the artifacts. However, the decision to return the objects was prompted by the Thai government's desire to protect the country's image from being tarnished by a possible perception of Thailand as a centre for trading in smuggled antiques and to present a goodwill gesture to Cambodia.(contr.Kr.K.)

\section{CUSTOMS}

\section{Relocation of headquarters of the Regional Intelligence Liaison office}

The (24) participants to the annual conference of the Asian Regional Office agreed on 30 October 1996 to relocate the regional headquarters for exchanging customs information to Japan from Hongkong in 1999.

The Regional Office is one of ten regional offices world-wide which are designed to co-ordinate policies and exchange information regarding the fight against smuggling such goods as drugs and firearms on a regional basis.(JT 31-10-96)

\section{DIPLOMATIC AND CONSULAR IMMUNITY AND INVIOLABILITY}

\section{Breach of inviolability of UN premises}

As they captured the Afghan capital Kabul the Taleban militia caught and killed the former Afghan president who had sought sanctuary in the UN compound for the past four years.

The Muslim Mujahideen had refused to let him leave the country to join his family in India. The government's troops who guarded the gates of the UN office building to make sure he could not escape but who also promised the UN to protect him, however, had fled from the Taleban forces.

The UN Secretary General deplored the abduction of a person who had sought sanctuary in UN premises and called it a breach of the inviolability of UN premises.(AsahiEN 28-09-96;JT 29-09-96) 


\section{Forceful entry into Japanese consulate in Hongkong}

Protesting against Japan's claim to the Diaoyu (Senkaku) Islands demonstrators in Hongkong broke into the japanese consulate. They unfurled a banner and tried to debate with consular officials. The protesters stayed for about 30 minutes and then left.

The Chinese foreign ministry said: "We do not approve of the methods used by some people of forcefully entering foreign consulates". The Hongkong governor called the incident serious. While saying he understood feelings were running high over the islands, there was no justification whatsoever for a break-in to diplomatic premises.

The consulate said it would ask the Hongkong authorities to "ensure our security".(Daily Yomiuri 10-10-96;AsahiEN 11-10-96)

\section{Demonstrations against German embassy in Tehran}

As a result of the German allegations of Iranian involvement in the Mykonos case (see:Jurisdiction) demonstrations took place outside the German embassy in midNovember 1996. The protests were reported to be initially sanctioned by the authorities, but later Iranian security forces encircled the embassy to hold off the demonstrators while hundreds of riot police waited nearby.(IHT 20-11-96)

\section{Occupation of Japanese embassy in Peru}

On 18 December 1996 the residence of the Japanese ambassador was occupied by members of the Peruvian Tupac Amaru Revolutionary Movement. The attackers held hundreds of persons, who were attending a reception at the embassy, hostage, demanding the release of several hundred jailed comrades.(IHT 19-12-96) Two months later the Peruvian president acknowledged that the intelligence service and the national police had been negligent in protecting the ambassador's residence, as they knew about transportations of weapons by the rebels into the capital, but failed to act on the information.(IHT 26-02-97)

The crisis ended on 23 April when Peruvian soldiers stormed the residence, rescued the hostages but one, and killed the rebels.(IHT 23-04-97)

\section{DIPLOMATIC AND CONSULAR RELATIONS}

See also: Civil war (Afghanistan), Inter-state relations (China-India)

\section{India - Pakistan}

It was reported in October 1996 that India detained a Pakistani diplomat and ordered his expulsion for alleged spying, which Pakistan condemned as 'illegal'. Pakistan retaliated by detaining an Indian diplomat which in turn prompted a protest from India.(FEER 10-10-96:15)

\section{Malaysia - Holy See}

Malaysia and the Vatican agreed to establish formal diplomatic relations, probably in 1997.Malaysia has some 600,000 Catholics.(FEER 17-10-96:14) 


\section{Consular presence in Hongkong after the handover}

It was reported that China would not permit the continuous functioning in Hongkong of the consulates of 13 countries which recognize the government at Taipei.(FEER 29-08-96 p.13)

China and the US were reported negotiating an agreement on the US consular presence in Hongkong after 1 July 1997. One of the sensitive matters was the existence of a Defense Liaison Office in the consulate, and the US wish to continue naval visits to Hongkong.(FEER 21-11-96:23) Another difficult issue was the status of US citizens in Hongkong, in particular those of Chinese descent, who may be regarded by China as Chinese nationals.(FEER 05-12-96:31)

\section{Sino-Philippine exchange of military attaches}

China and the Philippines had started to exchange military attachés. This was one of several agreements reached during the visit by the Philippine defence minister to China in July 1996, the first such visit by a top Philippine defence official.(IHT 0312-96)

\section{Expulsion of US and Indian diplomats}

India expelled two US diplomats in January 1997, one of whom reportedly had unauthorized links with a director in charge of the anti-espionage division of India's Intelligence Bureau. By way of retaliation the US expelled two Indian diplomats in February 1997 because of "activities that were incompatible with their consular status”.(IHT 17-02-97;FEER 27-02-97:13)

\section{Iran-European diplomatic relations}

After the ruling of the Berlin court of 10 April 1997 in the Mykonos case (see: Jurisdiction), the German government recalled its ambassador in Iran, followed by the other European Union member states, except Greece, which followed later.(IHT 1104,12/13-04,18-04-97;NRC 11-04-97) Germany also expelled four Iranian diplomats, which was retaliated by Iran's expulsion of four German diplomats.(IHT 14-04-97) A fortnight later, however, it was reported that the European countries would soon send back their ambassadors to Tehran, indicating that many European states were reluctant to risk damage to their economic interests in Iran.(IHT 29-04-97) Germany exported DM 2.2 billion of goods to Iran in 1996 and was the latter's biggest trading partner in Europe.

When Iran blocked the return of the German and Danish ambassadors, the two countries that had led the campaign for EU diplomatic sanctions, the EU urged its members not to send their envoys back, frustrating the attempts to contain the damage.(IHT 02-05-97) 


\section{DISARMAMENT AND ARMS CONTROL}

\section{Comprehensive Test Ban Treaty}

The 61-nation Disarmament Conference failed to reach agreement within its selfimposed deadline in late June 1996, mainly over India's insistence on a time-bound commitment by the five declared nuclear powers to scrap their nuclear arsenal. Besides, India also wanted the treaty to ban "non-explosive techniques for refinement of nuclear weapons", as appeared from a statement by the Indian foreign minister at the ASEAN Dialogue Partner meeting. India first proposed a ban on nuclear weapons testing in 1954.

On the other side the UK, Russia and China insisted that the three 'threshold states' - India, Pakistan and Israel - must be among the adherents to the Treaty.(IHT 01-07-96) This was included in the draft as it stood when the conference reconvened on 29 July.(IHT 31-07-96)

China's specific concerns with the existing text of the draft-treaty were about verification of tests and on-site inspections.(IHT 26-07-96) Not having the 'national technical means' (satellites with detection sensors) it aimed at an international monitoring network. Yet the head of its delegation demanded further changes in the draft in order to prevent the unacceptable prospect of nuclear "inspectors coming and going like international tourists". Under the draft a simple majority of a 51-nation executive council could authorize inspectors to go to a suspected test site on suspicion that the state concerned had violated the treaty. China first demanded a two-thirds majority, but in early August 1996 a compromise was reached between China and the US on the requirement of 30 votes. The agreement cleared the way for a joint declaration by the five declared nuclear powers that they were prepared to accept a common treaty text forever banning all nuclear test explosions. China had given up its demand for an exception for 'peaceful nuclear explosions' but insisted on a right to review the treaty after 10 years.

Pakistan took the position of signing the treaty only if India also did so.

Iran made objections concerning US satellite monitoring, the status of Israel under the draft treaty and the lack of a timetable for nuclear disarmament. Israel would be member of the executive council as representing the Middle East grouping of states rather than as a Western nation.(IHT 27/28-07-96,02, 08,13 and 14-08-96;FEER 2908-96:14)

After the failure to achieve the necessary unanimity for the draft treaty at the Geneva Conference on Disarmament, Australia submitted the text of the draft by way of draft resolution to the United Nations General Assembly on 9 September 1996 (A/50/1027), thus trying to avoid the unanimity requirement of the Geneva conference.

On the same day India proposed an amendment by, inter alia, adding two new paragraphs in Art.I:

"Each state party undertakes to refrain from any activity relating to the development, refinement and qualitative improvement of nuclear weapons. All states parties commit themselves to taking effective measures for global nuclear disarmament by commencing negotiations on a phased programme of nuclear disarmament and for the eventual elimination of nuclear weapons within a time-bound framework."(A/50/1036) 
The General Assembly resolution was adopted by 158 to 3. India, Bhutan and Libya voted against, Cuba, Lebanon, Syria, Tanzania and Mauritius abstained.(IHT 12-09-96)

On 26 October 1996 the treaty had been signed by 129 states, including the five declared nuclear powers and all but three of the states that must sign and ratify before the treaty could enter into force. The three were India, Pakistan and North Korea. The treaty requires 44 states known to have nuclear weapons, reactors and research programs in order to enter into force. On the above date only Fiji had ratified.

India has vowed never to participate in what it called an unequal treaty until the nuclear weapon states would devise a timetable for destroying their nuclear arsenals.(JT 30-09,27-10-96)

\section{US efforts to prevent Chinese supply of advanced nuclear and missile technology}

The US had been trying for a considerable time to prevent China from supplying nuclear and missile technology to various countries, such as Iran, Pakistan and Syria. China agreed in May 1996 not to provide technology to facilities of other states that were not subject to international inspections.(JT 10-11-96)

\section{Chinese attitude toward nuclear weapons}

China conducted a nuclear test on 29 July 1996, its forty-fourth since 1964, promising it would be its last. It announced a moratorium to all tests, effective 30 July.(UN doc. A/51/262;IHT 30-07-96)

In a statement issued right after the test on 29 July 1996 China appealed for, inter alia, the abandonment of policies of nuclear deterrence, the undertaking not to be the first to use nuclear weapons at any time and under any circumstances, the unconditional commitment not to use or threaten to use nuclear weapons against non-nuclearweapon states or nuclear-weapon-free zones, the withdrawal of nuclear weapons deployed outside the borders of the state, and the support of and respect for nuclearweapon-free zones. (A/51/262)

Vis-à-vis Taiwan, however, the chief Chinese arms negotiator said that since Taiwan is not a separate state, "so the policy of no-first-use does not apply".(IHT 06-0896)

\section{Failure to conclude Sino-US 'de-targeting agreement'}

The US secretary of state broached the drafting of a Sino-US agreement pledging not to target each other with nuclear missiles. It would be largely symbolic since neither side was currently aiming weapons at the other. The Chinese condition was that both countries would pledge never to be the first to use nuclear weapons. On the other hand, the US nuclear defence policy relied on the deterrence of a possible first strike.(IHT 26-11-96;FEER 28-11-96:14)

\section{Rejection of 1998 target date for verification regime}

Non-aligned countries at the review conference of the 1993 Chemical and Biological Weapons Convention in November-December 1996 prevented the adoption of a US-EU proposal to establish a verification regime in 1998. Instead the final declaration adopted by the conference urged an ad hoc group which had been assessing the 
feasibility of verification measures since 1995 , to intensify its work "with a view to completing it as soon as possible before the commencement of the fifth review conference" in 2001.

Non-aligned countries, led by India and Pakistan, also resisted the idea of on-site inspections which they deemed intrusive and a measure of last resort. They also called for lifting current export controls, a move which was blocked by Western states.(JT 08-12-96)

\section{Chemical weapons convention}

China submitted its ratification of the 1993 Convention on 25 April 1997, just four days before its entry into force. Of the other permanent members of the UN Security Council France had ratified in 1995, the UK in 1996, and the US just a day before China. Russia was the only member who had not yet ratified.

By ratifying before the entry into force a state became a co-founder of the Organization for the Prohibition of Chemical Weapons, and thus entitled to membership of the executive committee which will direct monitoring and have access to confidential data on world stocks of chemical weapons.

China was previously reluctant to sign the treaty because of the monitoring and inspection procedures, which it feared could be used to interfere in its domestic affairs. According to China the only chemical weapons in its territory were those left behind by Japan during the second world war (see AsYIL Vol.2:384, Vol.3:454, Vol.5: 508). The US alleged in the early 1990s (see . 4AsYIL 443) that China had been helping Iran to develop chemical weapons.(IHT 29-04-97)

\section{DISSIDENTS}

\section{Call to foreign countries for sanctions}

The Myanmarese opposition leader AUNG SAN SUU KYI called on foreign countries to impose economic sanctions against her country to force political reform on the government. She made her call on a videotape smuggled out of Myanmar.

In a parallel move the All Burma Students Democratic Front called on ASEAN countries to end their policy of constructive engagement and instead encourage dialogue with AUNG SAN SUU KYI.(IHT 19-07-96)

\section{DIVIDED STATES: CHINA}

See also: Arms supply, Diplomatic and consular relations, Inter-state relations (ChinaSouth Africa, China-US, China-Vatican, China-EU)

\section{Taiwanese refusal of reunification along Hongkong lines}

The Taiwanese president said on 2 July 1996 that the territory rejected reunification under the 'one country, two systems' model.(IHT 03-07-96) 


\section{Joint oil and gas exploration}

The Chinese Petroleum Corp. of Taiwan and the China National Overseas Offshore Oil Company of mainland China signed a contract on 11 July 1996 for joint exploration for oil and natural gas in a 15,400 square kilometre area between southern Taiwan and the Guangdong coast. In deference to Taiwan's official ban on direct investment, Chinese Petroleum entered the deal through a subsidiary based in Panama.(FEER 25-07-96:16)

\section{Taiwanese investments on the mainland}

Following remarks by the Taiwanese president calling for limits to the island's investments on the mainland (15 August 1996), the government postponed approval of a $\$ 3$ billion investment by Formosa Plastics Group. It would have been the largest seeTaiwanese investment on the mainland and was intended for the building of six power plants. The application was later withdrawn, but in early 1997 it was reported that construction in Fujian Province had begun with funds coming from the company's US subsidiary.

Although the Taiwanese authorities had banned direct investment on the mainland since 1949 , there had been, according to the economic ministry at Taiwan, since the 1980s, when Taiwan allowed indirect investment, through 1995, $\$ 5.6$ billion in approved Taiwanese investment through overseas affiliates. Independent estimates, however, put total Taiwan investment at $\$ 30$ billion by more than 30,000 Taiwanese companies.(IHT 17/18 and 19-08-96;ST 09-04-97;FEER 29-08-96:62,13-02-97:57,10-0497:65)

In connection with the change of recognition by South Africa from the government at Taipei to the central government at Beijing, the Taiwanese government said it would not approve closer economic links with the mainland by way of retaliation.(IHT 30-11/01-12-96) Some months later the Chinese vice-premier urged the Taiwan authorities not to prevent its entrepreneurs from investing on the mainland.(ST 09-0497)

\section{Direct shipping links}

China issued regulations on 20 August 1996, paving the way for direct shipping links since 1949. As a result the days for Hongkong as a lucrative entrepot would be numbered.(IHT 21-08-96;FEER 29-08-96:13)

The two sides met and reached agreement on 22 January 1997. Shipping companies from China and Taiwan could apply to their respective cross-strait shipping associations to conduct direct trade between the ports of Fuzhou and Xiamen in southeastern China and Kaohsiung in southern Taiwan. The two sides must begin direct links as soon as possible. Chinese approval for the first six Taiwan ships, reciprocating Taiwanese permission for five mainland carriers was given in April 1997.(IHT 11/1201,23-01,18-04-97)

The (second) Chinese ship, following shipping practices, hoisted the port state flag upon entering the port of Kaohsiung.(FEER 13-03-97:13;IHT 21-04-97) 
Foreign trips by Taiwanese foreign minister

(see also: Inter-state relations (China-EU)

The Taiwanese foreign minister made two trips to Indonesia and Malaysia to meet privately with the foreign ministers of those countries.(FEER 19-09-96:13)

In connection with a visit by the Taiwanese foreign minister to Jordan, the spokesman of the Chinese foreign ministry said:

"We deeply regret and express our strong dissatisfaction with Jordan and other states for allowing a visit ... We are resolutely opposed to the development of government links or any other form of official contatcs with Taiwan by any states that have diplomatic ties with our country."(IHT 20-12-96)

On 22 May 1997 the European Parliament's Foreign Affairs Committee met with the minister. The EU meets with Taiwan once a year, reportedly for economic talks while avoiding any political dialogue.(FEER 05-06-97:13)

\section{Taiwanese efforts to enter international organizations}

Taiwan's attempt to 're-enter' the UN failed for the fourth time in 1996 (see 6 AsYIL 365). The relevant UN committee on 18 September 1996 decided without a vote not to put the issue before the General Assembly.

A Taiwanese foreign ministry official said that "our UN bid was not to challenge their UN seat, or to push for 'two Chinas' or 'one China one Taiwan', but for the sake of survival and development of the 21 million people in Taiwan".(IHT 20-09-96)

As an alternative Taiwan in early April 1997 applied for observer status with the WHO, and announced its intention to make similar applications in other agencies. The WHO spokesman said, however, that the director-general did not consider it appropriate to invite Taiwan to observe the annual WHO Assembly.(FEER 08-05-97:24)

\section{Papua New Guinea attitude}

Papua New Guinea was among the states supporting a proposal to set up a special committee by the UN General Assembly to study Taiwanese UN membership in September 1996. The proposal was defeated for the fourth year in a row.(FEER 10-1096:15)

\section{Intra-Chinese contacts urged}

The Taiwanese president urged China on 10 October 1996 to increase contacts with Taiwan, but criticized the Chinese government for pursuing a hard-line policy which is detrimental to the reunification goal shared by the two parties.(AsahiEN 1110-96) Addressing a meeting of the National Reunification Council he pledged on 21 October to reunify Taiwan with China but blamed the 'stubborn policy' of the mainland's leadership for a stalemate in the relations. He iterated Taiwan's long-standing policy that reunification was a 'historic mission'.(IHT 22-10-96;JT 22-10-96) 


\section{Taiwan as a 'political entity'}

It was reported that Chinese analysts had raised the idea of recognizing Taiwan as a 'political entity' in order to break the deadlock in the reunification discussion. The idea could be made without compromising China's insistence on one central government.(FEER 10-10-96:14)

\section{Representation of China Airlines}

China Airlines, majority-owned by the Taipei government, opened a business office in Beijing.(JT 02-11-96;FEER 14-11-96:83)

\section{South Africa cuts diplomatic relations with Taipei in favour of Beijing}

South Africa had always recognized the Taipei government as the legal government of China. It had received direct investment and aid from Taiwan thought to run into hundreds of millions of dollars, and Taiwan had been its seventh-largest trading partner. But since the establishment of the post-apartheid government bilateral trade with mainland China had risen from $\$ 14$ million to $\$ 1.33$ billion.

The South-African president announced on 27 November 1996: "We have now granted diplomatic recognition to the People's Republic of China. We will cancel our diplomatic relations with Taiwan with effect from December 1997". He expressed the hope that "within the next 12 months it would be possible to achieve a smooth transition" allowing South Africa to remain friends with Taiwan.

As to South Africa's wish to have ties with both governments the president said: "Beijing made it clear they would not tolerate that. And it is impossible to move forward on the basis of dual recognition."(IHT 01-07-96;JT 29-11-96)

\section{Dalai Lama in Taiwan}

The Dalai Lama visited Taiwan for the first time in late March 1997 at the invitation of the Chinese Buddhist Association, despite a warning from China. The head of the Association as well as the (Taiwan) government Mainland Affairs Commission said that the visit would be exclusively in the Lama's capacity as a religious figure, but he nevertheless had meetings with the Taiwanese president and vicepresident.(IHT 14-01,24-03,26-03-97)

While in Taiwan the Dalai Lama said that he agreed with the Chinese contention that Taiwan is part of China and should not become a separate, independent state. He appealed to Taiwan and his followers to seek a compromise with China and said that he very much believed in the spirit of 'one country two systems'.(IHT 25-03,28-0397)

\section{Exchange of hijackers}

China gave in to a Taiwanese demand to repatriate a man who was suspected of having hijacked a domestic Taiwanese airliner on 10 March 1997 and forcing it to Xiamen on the southeastern coast of the Chinese mainland. At the same time the Chinese authorities called on Taiwan to send back 16 persons who had hijacked Chinese airplanes to Taiwan in the past.(IHT 21-03-97) 
China at first refused to hand over the hijacker, accusing Taiwan of failing to honour its commitment to repatriate Chinese hijackers under an agreement between the two sides (see 5 AsYIL 404).(IHT 15-05-97)

\section{Taiwan intelligence agents in Hongkong}

It was reported that Taiwan would pull out its intelligence agents based in Hongkong in view of the coming return of Hongkong to Chinese rule. However, the (policy-making) Mainland Affairs Council said it would continue to operate openly in Hongkong after June 1997 under the terms of the (Taiwanese) Hongkong-Macau Relations Act, enacted on 18 March 1997.(ST 08-04-97)

\section{Switching diplomatic relations}

Taiwan established diplomatic relations with Sao Tome and Principe at the West Africa west coast in early May 1997.

The government at Taiwan announced on 18 May 1997 that it was to sever relations with the Bahamas after it learned that the latter planned to switch recognition to the Chinese government at Beijing. The Taiwanese foreign minister said that "one of the reasons we did this was to prevent a domino effect from happening". It was reported that the Bahamian shift might be caused by its concern for a newly opened container port run by a Hongkong company in view of the impending hand-over of Hongkong to China.(IHT 07-05-97,20-05-97;FEER 29-05-97:13)

\section{DIVIDED STATES: KOREA}

\section{Joint venture enterprise}

A $\$ 10$ million venture between Daewoo of South Korea and the Korea Samchonri Group of North Korea would start operations on 19 August 1996. It would produce garments and other consumer goods for export markets. The project was a 50-50 partnership.(FEER 15-08-96 p.71)

\section{Submarine incident}

On 18 September 1996 a North Korean 325-ton Shark-class submarine was discovered stranded on a reef off the east coast of South Korea near Kangnung. An estimated 26 North Koreans went ashore, most of whom were later killed or found dead, and one captured.

North Korea claimed that the submarine was on a training mission and had drifted across the border because of engine trouble, and demanded the return of the vessel and its crew, including the dead bodies. It threatened on 26 September to retaliate for the killing of its military personnel as a result of the incident.(IHT 19-09-96;JT 27 and 29-09-96,06-11-96;AsahiEN 28-09-96)

The UN Security Council unanimously agreed on a (non-binding) presidential statement of 15 October, expressing 'serious concern' over the discovery of the North Korean submarine stranded in South Korea. The statement also said, inter alia, "The Security Council stresses that the armistice agreement shall remain in force until it is replaced by a new peace mechanism". The North Korean representative expressed 
satisfaction that the submarine incident was not expressly declared to be a violation of the armistice.(JT 13-10,17-10-96;AsahiEN 16-10-96)

South Korea demanded an apology from North Korea and steps to prevent the repetition of similar incidents, which demand was supported by the US. The demand was made a condition for further peace discussions and provision of aid. South Korea also announced an indefinite suspension of its participation in the nuclear deal with North Korea, consisting of helping North Korea build light-water nuclear reactors. On its part North Korea said it would temporarily abandon a border liaison office set up as a goodwill gesture in 1992, in response to the South Korean demand for an apology as a condition for the resumption of the dialogue.

The US later renewed a call for North Korea to make a gesture acknowledging that the submarine incursion was a serious mistake. Meanwhile the IAEA reported that North Korea was not making efforts to restart its nuclear program.(IHT 09/10 and 20-11-96; JT 09-11,12-11,25-11-96;Daily Yomiuri 10-10-96)

While in Manila for the APEC summit meeting in November 1996, the South Korean and US presidents urged North Korea to avoid further provocations and join in four-way talks with China, without referring to South Korea's demand for an apology.(IHT 25-11-96) It was widely acknowledged that there was some discrepancy between the US attitude which aimed at some general statement of North Korean regret, and the South Korean demand for a direct, unambiguous apology directed toward South Korea. It was also reported that North Korea was willing to express regret to the US, which signed the 1953 armistice agreement, but not to South Korea which was not formally a party to that agreement.(FEER 12-12-96:23)

Meanwhile negotiations took place in New York between North Korean and US officials, resulting in a North Korean statement of regret. The statement of $29 \mathrm{De}$ cember 1996 read:

"The spokesman of the Ministry of Foreign Affairs of the DPRK is authorized to express deep regret for the submarine incident in the coastal waters of Kangrung, South Korea, in September, 1996, that caused the tragic loss of human life. The DPRK will make efforts to ensure that such an incident will not recur, and will work with others for durable peace and stability on the Korean Peninsula".(IHT 30-12-96)

It was the first formal show of remorse by North Korea over military incidents since the 1953 armistice. In response South Korea handed over to North Korea the remains of 24 infiltrators who were killed in the course of the incident.

North Korea also said that it agreed to attend a meeting in New York to listen to an explanation on the proposed peace talks, and to resume the storage of spent nuclear rods, while the US agreed to 'take additional measures' to ease the embargo on North Korea and supply food.(IHT 31-12-96/01-01-97;FEER 09-01-97:15)

\section{North Korean acceptance of US presence in South Korea}

According to press reports North Korea had told China that it had made a number of proposals to the US for improvement of relations, among which concessions on the presence of US troops in South Korea.(JT 29-10-96) 


\section{No separate US-North Korean peace talks}

On the occasion of his visit to South Korea the South Korean and US defence ministers said that "separate negotiations between the US and North Korea on peacerelated issues cannot be considered."(JT 03-11-96)

\section{Chinese attitude toward four-way talks and Korean reunification}

According to South Korean sources China had said in November 1996 through its ambassador in Seoul that it was prepared to join four-way talks involving the two Koreas and the US. This would be the first unambiguous Chinese support for the talks proposed by the US and South Korea in April 1996 (see 6 AsYIL 423). The talks would be aimed at replacing the 1953 truce agreement with a permanent peace arrangement. The ambassador also said that the truce agreement should be maintained until a peace agreement was reached.(JT 19-11-96)

[Russia had suggested an international conference to end Cold War hostilities on the Korean peninsula. An eight-party conference would include the five permanent members of the UN Security Council, the two Koreas and Japan.](FEER 27-02-97:23)

On 29 January 1997 the Chinese president called on both Koreas to start peace negotiations that might eventually lead to reunification.(IHT 30-01-97)

\section{North Korean acceptance of peace talks in principle}

North Korea on 31 December 1996 agreed in principle to meetings in which it would obtain particulars about the US-South Korean peace proposals, but twice avoided briefing sessions in the following weeks.(IHT 05-02-97) Finally, the briefing meeting with South Korea and the US took place on 5 March 1997 in New York. It was the first time in 25 years that the two Koreas sat together talking about peace.(IHT 22/23-02,06-03-97) In a good-will gesture South Korea and the US canceled the joint 'Team Spirit' military exercises for the current year.(IHT 07-03-97)

At the New York talks North Korea responded to the peace talks proposals by demanding a guarantee of substantial food aid in advance. South Korea and the US took the position that the issue of food aid could be discussed in the four-party talks.(IHT 28-03-97) Apparently in an attempt to coax North Korea into joining the peace talks, South Korea on 31 March 1997 lifted its ban on private rice donations. It had not sent rice to North Korea since the summer of 1995 (see 5 AsYIL 411) except through the UN World Food Program.(IHT 01-04-97) When North Korea gave its response in April 1997 on its participation in peace-talks it essentially repeated its condition of additional food aid. The US expressed its willingness to consider further requests for food aid but insisted that such aid could not be given as a precondition for starting the talks.(IHT 23-04-97) A positive response was finally given by North Korea in late June. The four-way talks were planned to start in August 1997.(IHT 26-0697)

\section{Defection of high-level North Korean official}

On 12 February 1997 the top theoretician of the North Korean leadership who was one of the 11 members of the Secretariat of the Workers' Party of Korea sought asylum at the South Korean embassy in Beijing.(IHT 13-02-97) South Korea wanted safe passage for the person from Beijing to Seoul. On 18 March 1997 China sent the man 
by special plane to the Philippines from where he could, after some interval, travel to South Korea. A foreign ministry spokesman said that the 'problem' was solved through consultations among all interested sides.(IHT 19-03-97)

\section{Meeting of North and South Korean Red Cross officials}

Red Cross officials from North Korean and South Korea held their first meeting in five years in early May 1997 in Beijing to try resolve their disputes on the delivery of emergency food aid from South Korea. The three issues were: where the food aid would enter North Korea, how the packages would be labeled, and how the delivery would be monitored to make sure that the food got to the poor and hungry. The talks did not succeed in reaching an agreement, among other things because the South Korean side could not specify the amount of aid it planned to deliver.

On 23 May 1997 it offered 40,000 metric tons of food, twice the amount it had sent during the past two years. The amount was later increased to 50,000 tons. On 26 May the two sides reached agreement that South Korean donors would be allowed to target food aid to relatives or certain regions, and that delivery would be allowed in original packaging. However, the North Korean Red Cross rejected a proposal that the aid be delivered through Panmunjon; it was to go through China instead. The accord was the first between the two Red Cross societies since a 1985 agreement on hometown visits by displaced persons.(IHT 03/04-05,06-05,24/25-05,27-05-97;FEER 0506-97:13)

\section{ECONOMIC CO-OPERATION AND ASSISTANCE}

See also: Inter-state relations (China-Japan, Iran-Turkey)

\section{Water supply from Johor (Malaysia) to Singapore}

Johor agreed in principle to supply more untreated water to Singapore if the latter would require it, but would consider the interests of its people first before committing itself to a final decision on the issue.

Three of the treatment plants in Johor (Skudai, Gunung Pulai and Kota Tinggi) are operated by Singapore's Public Utilities Board (PUB). A Johor feasibility study was being conducted on, inter alia, buying back the treatment plants owned by the PUB. At present Johor exports untreated water to Singapore, where it is treated and resold to Johor for 50 Malaysian cents per 4,540 litres. If treated in Johor, it would cost 70 Malaysian cents.

In May 1996 the government of the state of Johor announced a decision to stop selling unprocessed water with immediate effect, but the decision would not affect current agreements with Singapore and Malacca. Singapore is getting its water from Johor under two agreements. The first expires in 2011 and the second in 2061.(ST 1309-96)

\section{Official development aid and non-governmental organizations}

It was said in senior circles of the Japanese foreign ministry that Japan would strengthen co-operation with non-governmental organizations as part of its future 
official development assistance policy. It was acknowledged that such co-operation only began as recently as 1989 .(JT 10-10-96)

\section{World Bank aid for Vietnam}

The Consultative Group for Vietnam pledged \$2.4 billion in aid for Vietnam on 6 December 1996. The amount for 1997 was higher than expected because Japan came in with more aid than expected. Its contribution accounted for more than a third of the total assistance. During a visit by the Japanese prime minister in early January 1997 an agreement was signed for $\$ 764$ million in soft loans and grants.

The Vietnamese reform process had brought average economic growth of more than 8 percent for the past five years.(JT 07 and 08-12-96;FEER 23-01-97:13)

\section{Japanese aid to Myanmar}

(see 6 AsYIL 368)

It was reported that Japan offered to resume development aid if the military government showed more respect for human rights.

After its suspension of aid in 1988, Japan had resumed aid for projects which were already under way in 1989.(IHT 14/15-06-97)

\section{EMBARGO}

\section{US export of super-computers to China}

Since deregulation of US export of computers in 1995, China had bought tens of supercomputers. According to US government officials, these computers would allow China to conduct underground nuclear weapons tests with explosions so small as to be undetectable by outsiders but of which the data could nevertheless be processed by the supercomputers. US government officials rejected suggestions to hold up further deregulation as it would be impossible to prevent China from obtaining the computers from other sources.(IHT 11-06-97) China on 12 June 1997 dismissed allegations that it had diverted the supercomputers to its military.(IHT 13-06-97)

EMERGENCY AID

\section{Chinese food aid to North Korea}

(see: Inter-state relations:China-North Korea)

\section{Co-operation in responding to disasters}

Twenty-eight countries among which eight Asian countries held a conference in late October 1996 to discuss how to co-operate in responding to natural disasters.(JT 24-10-96)

\section{Japanese attitude toward North Korean famine}

The Japanese government was criticized for its refusal to use its huge stockpiles of surplus rice to provide North Korea with emergency aid. The prime minister said it 
would be difficult for Japan to give aid in light of recently disclosed evidence suggesting that North Korean agents had kidnapped several Japanese citizens in the 1970s and allegedly brought them to North Korea to teach Japanese behaviour and language to North Korean spies.(IHT 25-03-97) Later the Japanese prime minister hinted that Japan might reverse its policy and agree to provide aid if South Korea formally asked to do so.(IHT 30-05-97)

Japan had shipped 500,000 tons of rice to North Korea in $1995,150,000$ tons free and the rest on a 30-year loan. Through the UN it gave $\$ 500,000$ in 1995 and $\$ 6$ million in 1996.(IHT 28-03-97)

\section{US and EU aid for North Korea}

In a move with humanitarian and political reverberations, the US committed itself to provide $\$ 15$ million in new food aid. The announcement came one day before North Korea would inform the US whether it would join the proposed peace negotiations.

The UN World Food Program had called on states to provide $\$ 95.5$ million in aid. Before the US commitment $\$ 22$ million had been raised.(IHT 16-04-97) The EU subsequently committed itself to send 155,000 tons of food, worth $\$ 69$ million, in response to the WFP appeal. A EU Commission spokesman said that the aid should also help avert a possible deterioration in the security situation of the Korean peninsula. The EU insisted to be allowed to make its own assessment of conditions in the country and to monitor the distribution, to which North Korea reluctantly agreed.(IHT 27-0597;FEER 05-06-97:21)

\section{ENVIRONMENTAL POLLUTION AND PROTECTION}

\section{'Greenhouse gases' after 2000}

The 1992 UN Framework Convention on Climate Change includes a non-binding call for industrialized countries to stabilize their emissions of carbon dioxide and other greenhouse gases at their 1990 levels by 2000. At their conference in July 1996, however, the signatory states agreed in principle to set a legally binding target for industrialized countries for the period after 2000.

It was reported that Japan would submit proposals on targets of reducing the emission of 'greenhouse gases' after the year 2000. The proposals were said to include alternative numerical targets. One target figure would be the rate of a cut in the national output of carbon-dioxide. Another would be the per-capita-output volume of the gas. The proposals would require each industrialized country to choose between the two targets. The Japanese proposals were expected to draw criticism from some countries, especially in Europe, that have made more progress in cutting back their emission volumes.(JT 31-10-96)

\section{Dumping of waste by Japan}

According to government reports Japan dumped 43.32 million tons of waste into the sea in 1995, either as waste or as reclaimed land, 390,000 tons more than in 1994. Dredging accounted for 74.1 percent, industrial waste for 15.1 percent and non- 
industrial waste for 10.8 percent. More than 20 percent of the dumped industrial waste possibly contained toxic substances.

Japan is the only major industrial country to dump raw sewage into the sea because of a shortage of raw sewage treatment facilities.(JT 02-11-96)

\section{Oil spill on Japanese north-central coast}

The Russian-registered oil tanker 'Nakhodka' sank and broke in two off Fukui on western Honshu island in the Sea of Japan, 150 kilometres off the coast, on 2 January 1997, causing Japan's second-worst oil spill since 1971. The oil slick fouled the coast and threatened fish and wildlife.(IHT 08,10,11/12-01-97;FEER 23-01-97:13)

\section{ESPIONAGE}

\section{North Korean charges against US citizen}

North Korea notified the US it was charging an American with illegal entry and espionage. The American was arrested in August 1996 after crossing into North Korea from the Amnok (Yalu) River border with China. The person was allegedly sent for espionage by the South Korean Agency for National Security Planning. US officials said the man was the son of an American father and a Korean mother, and did not work for the US government in any capacity.(IHT 07 and 08-10-96; JT 10-10-96)

The man was released on 27 November 1996. The US congressman who successfully negotiated the release, told that there was no quid pro quo for the release, that the US paid a 'small amount' of money (later the amount of $\$ 5,000$ was reported) to cover a 'hotel fee' as the man was allowed to stay in a hotel for two months, and that although North Korea imposed a fine on the man's unauthorized entry into the country (later the amount of $\$ 100,000$ was reported) it was not paid.(IHT 23/24, 26 and 2811-96;JT 28 and 29-11-96)

\section{EXTRADITION}

See: Hongkong, Inter-state relations (Cambodia-Thailand)

\section{FAUNA AND FLORA}

\section{Japan's position on ivory trade}

High on the agenda of the conference of states parties of the Washington Convention on International Trade in Endangered Species of Wild Fauna and Flora (CITS) in June 1997 was likely a call by a number of African states to relax the 1989 ban on ivory trade. The African states had urged Japan to co-sponsor the proposal which was put forth in summer 1996.(JT 12-12-96) 


\section{FISHERIES}

\section{Taiwan-Japan talks}

The two parties would hold talks on 4 October 1996 to discuss fishery issues arising from their rival claims to the Senkaku or Diaoyu islands. These talks would be the second round since the dispute over the islands flared in July.(AsahiEN 03-10-96)

\section{Arrest of Japanese fishermen by Russia} (see also: 1 AsYIL 346)

A Japanese fishing boat was seized on 12 October 1996 about 3.9 kilometres inside Russian waters from a Russian-set borderline dividing Japan and Russia off the Russian-held but disputed island of Kunashiri (one of the four islands belonging to the Japanese 'Northern Territory', see 1 AsYIL 346). The fishermen were suspected of violating Russian waters and poaching. Japan asked Russia to release them as soon as possible.(JT 17-10-96) The charge of poaching was later dropped while Russia said it would release four of the five crew members.(JT 20-10-96) The fifth was later released in November without trial for want of material evidence, although the man was prevented from leaving the Russian Far East till the end of the month.(JT 12-11,3011-96)

\section{Annual Japanese-Russian negotiations}

The two countries agreed on an unchanged annual quota for 1997 of 100,000 tons each for fish caught within each other's 200 nautical mile exclusive economic zone. Besides Russia agreed to allow Japan to catch an additional 9,000 tons against payment of 400 million yen. The agreement was based on their 1984 fisheries agreement.

Japan was also to introduce an international quota system called the Total Allowance Catch, designed to protect marine resources through close monitoring and fishing quotas.(JT 26-11,08-12-96)

\section{Illegal fishing}

Thai fishing industry is known to be most dominating in southeast Asian waters, with Thai fishing boats catching illegally in waters under jurisdiction of other states, such as the waters off Myanmar, Malaysia, Cambodia, Vietnam and Indonesia. As a result skirmishes had started to occur with naval vessels of these states, and hundreds of Thai fishermen were in jails from India and Bangladesh to Vietnam and Indonesia. It is reported that the fishing boats are often better armed than their naval opponents.(FEER 13-03-97:54)

\section{FOREIGN INVESTMENT}

See also: Joint development, Oil and gas

\section{Indonesian natural gas exploitation}

A change occurred in the number of shares held by the participants in the projects relating to the exploration and exploitation of the D-Alpha Block gas field near Natuna 
Island.(see 5 AsYIL 416) The Indonesian partner, Pertamina, sold $26 \%$ of its $50 \%$ stake to Mobil Oil, and planned to sell another $13 \%$ to a consortium of Japanese companies.(FEER 12-09-96:54-55,24-10-96:70;JT 19-11-96)

\section{Enron investment project in India}

(see also: 5 AsYIL 418, 6 AsYIL 376)

Formal government approval was won in July 1996 but was still entangled in a court case initiated by a trade union challenging the government approval of the project. The court was expected to rule in September 1996.(FEER 26-09-96:55)

\section{Foreign investment in Myanmar}

Under pressure of groups critical of the government of Myanmar the Dutch brewery Heineken announced its withdrawal from a $\$ 30$ million investment in early July 1996. Its share was taken over by Fraser \& Neave Ltd of Singapore. Originally the two companies, through their joint Asia-Pacific Breweries, had planned a $60 \%$ stake in a joint venture with a company in Myanmar which was controlled by the military. Similarly the Danish brewery Carlsberg abandoned another brewery project, whereupon the Myanmar partner had started negotiations with Asia-Euro Brewery Sdn of Malaysia for continuation of the project. Other companies that had withdrawn from Myanmar included, inter alia, Eastman Kodak, Walt Disney, Hewlett-Packard, Liz Clayborne, PepsiCo. Pressure was also exerted on multinational companies like Unocal Corp., Texaco Inc. and Atlantic Richfield of the US and Total of France.

Unocal and Total had a joint venture with Myanmar Oil and Gas Enterprise to develop a natural gas project in the Gulf of Martaban (Andaman Sea), south of Yangon, and in late January 1997 it was announced that the Unocal and Total subsidiaries had entered a production-sharing contract with Myanmar Oil and Gas Enterprise for the exploration of oil and natural gas in a new area in the Andaman Sea. The area abuts the zone of the Yadana gas field (infra).

Texaco, in partnership with Myanmar Oil and Gas, Nippon Oil of Japan and Premier Oil PLC of Britain, is developing the second largest offshore gas field of Myanmar. Texaco would take 50 percent of the mining rights, Premier Oil 30 percent and Nippon Oil 20 percent. The exploration site is around 27,000 square kilometres and located 60 kilometres off Myanmar in the Andaman Sea.(IHT 16-07-96,31-01-97; FEER 25-07-96:81, 14-11-96:83;AsahiEN 30-10-96;JT 31-10-96) The project includes a 415-mile gas pipe line from the Yadana field to the shore and the Thai border. From there, a 161-mile Thai extension would carry the gas to a power plant near Bangkok. Thailand would pay $\$ 400$ million a year for the gas, half of which would go to the Myanmar government. Plans for developing additional offshore blocks were aborted by the US ban on new US investments which was issued in April 1997.

On the other hand Southeast Asian investments kept flowing into Myanmar. In 1995 Singapore was the biggest investor with almost $\$ 300$ million or about half of the total foreign investments of \$668 million.(IHT 12/13-10,09-12-96,24-04-97) 
Malaysian participation in Iran investment (see 6 AsYIL 378)

It was reported that the Malaysian national oil company (Petroliam Nasional, or: Petronas) had agreed to take a 30 percent stake in an oil field project, sharing the $\$ 600$ million investment burden with Total of France.(IHT 20-08-96)

\section{US-Hongkong investment promotion and protection accord (IPPA)}

It was reported in October 1996 that the efforts since 1991 to reach agreement on the matter had not yet materialized. One of the toughest differences involved the 'denial of benefits' provision, which would entitle the US to withhold investment protection from a company deemed to be using Hongkong as a base merely to benefit from the treaty ('treaty shoppers'). The US was concerned that companies from China, which is no WTO member, would pose as Hongkong companies and would benefit from the treaty in case of their investing in the US. It wanted to have the right to deny a Hongkong-based investor IPPA benefits if the US deems that its national security is threatened. The US also wanted clauses that would bar the transfer of certain hi-tech goods to third countries.(FEER 10-10-96:63,29-05-97:32)

\section{The idea of a global investment pact}

Under the title 'Trade and Foreign Direct Investment' WTO economists had issued a report arguing for a global trade agreement to bring foreign investment under binding international trade rules. The report collated the latest research on the matter, inter alia by the OECD.

While developed countries are supportive of the idea, developing countries are loath to negotiate such an agreement as it would limit their ability to control and direct foreign investment into their countries under national policies.

Foreign investment amounted to an estimated $\$ 315$ billion in 1995, and had become increasingly interlinked with trade.(AsahiEN 17-10-96;JT 18-10-96)

\section{Closure of main McDonald store in Beijing}

McDonald was to close its main store in central Beijing after holding out for two years against a removal order. It had agreed to move the restaurant after having resisted on the grounds that it had signed a 20 -year lease on the site. It would receive compensation for the move.(JT 03-12-96)

\section{Obstruction of Korean acquisition of French company}

The French government had planned to privatize the state-owned company Thomson S.A. and sell it (for the symbolic sum of one franc) to the Lagardere Group, which would have absorbed the Thomson-CSF defence contracting unit and sold control over Thomson Multimedia to Daewoo of Korea. However, France abruptly pulled out of the deal on 4 December 1996 after its privatization commission objected to ceding control over Thomson Multimedia to the Korean company. The French finance minister said that the commission had been reluctant because of the transfer of technology involved.(IHT 06-12-96) In addition the French government said it was not confident that Daewoo would meet a commitment to create jobs in France. The Fed- 
eration of Korean Industries responded by writing a protest letter to the French ambassador in Korea, demanding that appropriate steps be taken by your government to redress the matter". When the French government sent a presidential envoy to Korea to try to repair the damage, the Korean president said: "The South Korean people believe we have been totally discriminated against. ... We have a bad impression of France and have come to think France cannot be trusted."(IHT 12-12-96,15-01-97) The French government announced on 19 February 1997 that it would sell the defence company Thomson-CSF as a single unit at auction, but made it clear that Asian or American buyers need not apply. According to the government Thomson Multimedia would be put onto the market later in 1997.(IHT 20-02-97)

\section{Indian attitude toward foreign investment}

The Indian industry minister said that the government welcomed foreign investment but would protect domestic companies if they were in danger of being 'gobbled up' by multinational corporations. "We will give protection just as America gives protection to automobiles and semi-conductors."(IHT 07-02-97)

On 24 January 1997 the Indian government decided that foreign airlines would not be allowed to invest in domestic Indian airlines, although non-airline overseas investors were allowed to own up to 40 percent stakes in such airlines. The foreign airlines concerned were given a six-month deadline to disinvest. The underlying goal was to insulate state-owned Indian Airlines from competition.

The new guidelines put an end, inter alia, to a $\$ 780$ million plan by Singapore Airlines and the Tata business group of India to set up a new airline in India. The project had earlier received a green light from the Foreign Investment Promotion Board.

It was not clear whether foreign airlines could invest through holding companies and whether overseas Indians count as foreign or local investors. These issues were involved in the case of Jet Airways, owned by a holding company in which Gulf Air and Kuwait Airways each owned $20 \%$, the rest being held by overseas Indian investors.(FEER 16-01-97:55,06-02-97:55;IHT 5/6-04-97)

\section{National priority in Philippine investments}

The Philippine Supreme Court ruled that a Philippine company should be awarded a contract to buy a $51 \%$ stake in a government firm which was being auctioned, although the company was only the second-highest bidder after a Malaysian company. The Supreme Court took its decision on the grounds that the constitution gives preference to a national company.(FEER 13-02-97:57)

\section{Enron project in Bangladesh}

The Bangladesh Power Development Board on 24 May 1997 initialled a contract with Enron International \& Associates to set up a $\$ 100$ million power plant, the first investment by a foreign firm in Bangladesh on a build-own-operate basis. The final agreement was set for June 1997.(FEER 05-06-97:65) 


\section{Chinese investment in foreign oil industry}

China National Petroleum Corporation bought $60 \%$ of Aktyubinkskneft, the top oil company of Kazakhstan which is based near the Chinese border. The CNPC also concluded a contract for the development of two oil fields in Venezuela and a contract to develop the Ahdab oil field in southern Iraq. It also formed an oil and gas joint venture with Agip SpA of Italy, Chinagip Overseas Petroleum BV, based in the Netherlands.(IHT 06-06-97)

\section{HONGKONG}

See also: Diplomatic and consular relations, Foreign investment

\section{Agreement on container terminal facilities}

The agreement in principle between the Chinese and British sides on the matter (see 6 AsYIL 388) was implemented in such a way that the colonial company Jardine Matheson would be awarded berths at an older terminal and relinquish its leading role in the projected new facilities.(IHT 20-09-96)

\section{Japanese visa policy for Hongkong passports}

The governor of Hongkong pleaded with the Japanese government for a more liberal visa policy for Hongkong Special Administrative Region passports compared to Chinese passports after the territory would revert to Chinese rule.(JT 27-11-96)

\section{No protection for dual nationals}

The British foreign office said that the UK would not be able to give full consular protection to British nationals in Hongkong after the colony reverts to Chinese rule if they hold Chinese nationality besides.(IHT 05-12-96)

\section{Changes in human rights- and civil liberties laws}

It was reported that the Hongkong government-in-waiting would shortly release a consultation paper on planned changes in human rights and civil liberties laws. The changes would scrap some recent amendments to existing ordinances and would curb protests and overseas links of political groups.(ST 08-04-97)

\section{Nationality status of ethnic minorities}

About 8,000 people in Hongkong belonging to ethnic minorities would likely be left stateless after the hand-over (although retaining the right to stay in Hongkong). About half were of South Asian origin.

In view of their awkward status after the hand-over (6 AsYIL 384, 385) the United Kingdom introduced the British Nationality (Hong Kong) Act 1997 in March 1997. Under this Act persons, who were solely British nationals on 4 February 1997 and were ordinarily resident in Hongkong, are entitled to apply for registration as British citizens, with right to abode, as from 1 July 1997.(IHT 6/7-07-96,05-02-97;FEER 1302-97:13;UNdoc.CCPR/C/125) 


\section{Right of abode in Hongkong}

For the purpose of determining whether a Chinese person fulfills the requirement of residence at the time of the handover on 1 July 1997 in order to qualify for the right of abode in Hongkong, the Chinese government would not require physical presence in Hongkong on that date; it would suffice if the person returned to Hongkong within 18 months of the handover.(IHT 15-04-97)

A summary of the rules applying to the subject as agreed between China and the UK was contained in the final UK report in respect of Hongkong under the ICCPR as submitted to the UN Commission on Human Rights on 30 June 1997. (UNdoc. $\mathrm{CCPR} / \mathrm{C} / 125)$

\section{British objection to the establishment of a provisional legislature}

As a Chinese Selection Committee of 400 people gathered in the neighbouring Chinese city of Shenzhen to select the temporary body (see 6 AsYIL 388), the British foreign secretary invited China to settle the matter in the International Court.(IHT 21/22 and 23-12-96)

\section{International jurisdiction over Hongkong after its reversion to China}

A district court in Boston, US, ruled on 7 January 1997 that a Hongkong resident should not be extradited to Hongkong because his trial would take place after the territory's handover, and in light of the fact that no extradition treaty existed between China and the US. The court gave its ruling against the backdrop of an extradition agreement concluded (but not yet ratified at the time of the court ruling) between the US and the UK on behalf of Hongkong, which prohibits offenders from being turned over to a third jurisdiction.

In 1992 the US Congress passed the 'Hong Kong Policy Act' which commits the US government to recognize the reversion of Hongkong but allows the president to strip Hongkong of its separate legal status 'whenever' he thinks it is 'not sufficiently autonomous' from China.(FEER 23-01-97:17)

\section{Hongkong-Taiwan sea trade}

Shipping executives from Hongkong and Taiwan reached agreement on 23 May 1997 to ensure two-way trade would continue after the handover. Taiwanese ships would not fly a flag when entering Hongkong; Hongkong ships would hoist the flag of the local Hongkong Special Administrative Region when docking in Taiwan.(FEER 05-06-97:13)

\section{HUMAN RIGHTS}

See also: Inter-state relations: China-US

\section{Myanmar}

The ruling State Law and Order Restoration Council (SLORC) banned a congress that the National League of Democracy had planned to hold. According to the NLD the three-day meeting was to mark the eighth anniversary of its founding, but the 
government said that the NLD was colluding with the US embassy and aimed at disrupting national stability. According to these accusations the US had urged AUNG SAN SUU KYI to hold the congress to coincide with discussions of a sanctions bill against Myanmar in the US Congress. However, the US Congress was due to adjourn on 27 September and had yet to vote on the 1997 Foreign Operations Appropriations bill, which included an amendment urging Myanmar to improve its human rights record.

The US and the UK protested against the measure and demanded the release of those who had been detained in the effort to prevent the meeting. The US denied the accusation of a collusion and the UK said it would consult with its European partners on possible measures against Myanmar.(AsahiEN 28-09-96;JT 29-09-96)

Japan on 7 October 1996 renewed a call on the military government of Myanmar not to prevent the National League for Democracy leader from speaking to crowds.

\section{Discussion in the UN on Chinese human rights record}

China warned that relations with countries which join condemning China publicly in the UN Commission on Human Rights would suffer, but that it was prepared to hold dialogues with countries that refrain from such criticism.(IHT 04-04-97)

China requested other states, among which Japan, to support a resolution in the UN Commission on Human Rights aiming at avoiding the debate and voting on a draft-resolution on the Chinese human rights record. Japan rejected the request on the grounds that the Chinese-sponsored resolution sought to stem debate on the substantive resolution.(IHT 15-04-97)

On 16 April 1997 the UN Commission on Human Rights for the seventh time in a row rejected a draft resolution aiming at censuring China. Among the states refusing to support the rejection were France, Germany, Italy, Spain, Canada and Australia.(IHT 17-04-97) After the voting China retaliated against some European states which had backed the resolution, by cancelling high-level visits to these countries.(IHT 19/20-04-97)

\section{Workshop on Regional Human Rights Arrangements in the Asian and Pacific Region}

Since 1990 three workshops had been held under the auspices of the UN: in Manila (1990), Jakarta (1993), and Seoul (1994). A fourth Workshop was convened in Kathmandu (26-28 February 1996) pursuant to resolution 1995/48 of 3 March 1995 of the UN Commission on Human Rights, in which the Commission invited the states of the region to undertake actions for the establishment of a regional arrangement for the promotion and protection of human rights.

As it was considered premature to discuss specific arrangements relating to the setting up of a formal human rights mechanism in the region such as those existing in Europe, the Americas and Africa, the fourth Workshop put emphasis on exploring the options available and the process necessary for establishing a regional mechanism.

The Workshop was attended by representatives of 30 states of 'Asia' in the broadest sense of the word. In contradistinction to previous years, the 1996 Workshop ended with the adoption of (nine) 'agreed conclusions' instead of 'Chairman's concluding remarks'. The conclusions identified steps towards the establishment of a regional arrangement. The Workshop decided to set up an open-ended team comprised of 
representatives of interested governments of the region and the UN Centre for Human Rights, inter alia, for that purpose.

Conclusion 4 stated, inter alia, that the diversities and complexities of the region would require the process of establishing a regional arrangement to involve extensive consultations among countries in the region in order to arrive at consensus. A step-bystep approach was recommended, including the sharing of information and experiences and the building up of national capacities for the promotion and protection of human rights. The importance of confidence-building measures was emphasized.

According the conclusion 5, any regional arrangement would need to be based on the needs, priorities and conditions prevailing in the region. Consequently, the rationale for any such arrangement should emerge from within.(UN publ.HR/PUB/96/3)

\section{IMMIGRATION}

See also: Inter-state relations:China-South Korea

\section{Illegal immigration to Japan}

The Japanese police arrested 71 Chinese nationals on 1 May 1997 on suspicion that they illegally entered the country through the island of Kyushu. In the first two months of 1997692 foreigners had been arrested for illegal entry, of whom 84 percent were Chinese. There had been 679 arrests for all of the year 1996.(IHT 02-05-97)

\section{IMMUNITIES}

See: Diplomatic and consular immunity

\section{INSURGENTS}

See also: Borders, Refugees

\section{Christians against Philippine peace deal with Muslims}

It was reported that Christian politicians attacked, and the Roman Catholic Church urged to defer the plans of the Philippine president to offer a major role in the economic development of the southern Mindanao region to the Moro National Liberation Front. The Christian protests continued in the following months.(IHT 02-07,09-07,0908-96)

\section{Final agreement between Philippine government and MNLF} (see 6 AsYIL 390)

The agreement which was to bring the insurgency to a final and formal end was signed on 2 September 1996. A transitory Southern Philippines Council for Peace and Development would be established, headed by the leader of the MNLF. This would be followed in three years by voting in 14 southern provinces (coinciding with the 13 provinces referred to in the Tripoli agreement) with large Moro populations (called in the current agreement: 'Special Zone for Peace and Development') to determine the 
size of the projected final autonomous region, which would replace the presently existing four-province Autonomous Region of Muslim Mindanao.(IHT 20-08-96)

It appeared that a final solution of the whole issue would still meet many problems: only five out of the 13 provinces are Muslim-dominated, as a result of Christian immigration over the past decades. Besides, the powers of a regional governor, and, for that matter, of the Council for Peace and Development would be quite limited.

The rebellion started when President MARCOS proclaimed martial law in 1972 and, as a result, the Muslim leadership went underground. It claimed more than 120,000 lives. The 3-year long peace talks took place under the supervision of a committee of the Organization of the Islamic Conference presided by Indonesia.(FEER 05-09-96 p.24-27;IHT 02 and 03-09-96)

\section{Philippine government talks with Communist insurgents}

Philippine government negotiators left for the Netherlands on 12 September 1996 to resume peace talks with communist rebel leaders in exile in the Netherlands. The initiative came a week after the signing of a peace deal between the government and the Moro National Liberation Front, and some months after a peace arrangement with the remnants of a right-wing military group. An end of the rebellion by the Communist Party of the Philippines/New People's Army would complete efforts by the Philippine president to end all insurgencies in the country.(NST 13-09-96)

In late November the Communists suspended the peace talks after the government refused to release a detained leftist leader. Their National Democratic Front of the Philippines accused the government of violating an agreement on safety and immunity guarantees and considered terminating the negotiations because of these violations.(IHT 30-11/01-12-96) Eight days of peace talks were later held in the Dutch city of Utrecht in early February 1997.(IHT 10-02-97) They were resumed in March.(IHT 10-03-97)

\section{Philippine truce with Moro Islamic Liberation Front (MILF)}

The first-ever formal meeting between the Philippine government and the MILF (see 5 AsYIL 426) took place in Davao City on 3 August 1996. While a cease-fire accord was expected to be concluded on 19 September 1996, following the peace agreement with the Moro National Liberation Front (MNLF), an interim agreement was in fact signed on 27 January 1997.

[In 1987 the then Philippine president rejected an MILF proposal that it be included in the government's talks with the MNLF.]

In late December 1996 a meeting was held on Mindanao island under the name of 'Bangsa Moro People's Consultative Assembly', dealing with the issue of an independent Islamic state in Mindanao. The organizers consistently denied any links with the MILF.(FEER 15-08-96:12,26-12-96/02-01-97:22,06-02-97:13;IHT 13-09-96)

\section{Indian insurgents near Bangladesh border}

During a visit to Bangladesh by the Indian prime minister in early January 1997 the two countries agreed to co-operate in fighting insurgents near their border.(IHT 07-01-97) 


\section{Shanti Bahini insurgency in Bangladesh}

(see: 4 AsYIL 452)

The peace talks with the government had not yet achieved results, but were continued in early 1997.(FEER 06-02-97:13)

\section{INTELLECTUAL PROPERTY}

\section{Vietnam - US copyright treaty}

The two countries signed a copyright treaty in April 1997.(IHT 18-04-97)

\section{INTER-STATE RELATIONS: GENERAL ASPECTS}

\section{China - South Africa}

South Africa had always recognized the Taipei government as the legal government of China. It had received direct investment and aid from Taiwan thought to run into hundreds of millions of dollars, and Taiwan had been its seventh-largest trading partner. It had been represented in China by a 'South Africa Centre' in Beijing since 1992. But since the establishment of the post-apartheid government bilateral trade with mainland China had risen from $\$ 14$ million to $\$ 1.33$ billion.

The South-African president announced on 27 November 1996: "We have now granted diplomatic recognition to the People's Republic of China. We will cancel our diplomatic relations with Taiwan with effect from December 1997". He expressed the hope that "within the next 12 months it would be possible to achieve a smooth transition" allowing South Africa to remain friends with Taiwan.

As to South Africa's wish to have ties with both governments the president said: "Beijing made it clear they would not tolerate that. And it is impossible to move forward on the basis of dual recognition."(IHT 01-07,29-11-96;JT 29-11-96)

\section{China - US}

(see also: Diplomatic and consular relations, Foreign investment: Hongkong)

As the most senior US visitor to China since the 1994 visit by the Secretaries of State and of Defense, the US National Security Advisor came to China in early July 1996 , in order to try to minimize differences between the two states and to find out the possibilities of a presidential summit meeting. It was said that the parties agreed to take a long-term, strategic view of how to assess and manage their relations.(IHT 6/7,08 and 09-07-96)

It was reported that a change in US policy came about under the influence of warnings from US allies in the Asian region, withholding their support from US confrontation with China over sensitive questions of Chinese unity and security, and regarding actions encouraging the independence of Taiwan or Tibet as interference in China's internal affairs.(IHT 10-07-96)

There was a further sign of improved relations when the two sides agreed on a visit by the US secretary of state in November 1996. The visit was originally planned in 
spring but was postponed because of tensions over the Chinese missile tests and military exercises in the Taiwan Strait in March.(IHT 24-07-96)

On the other hand the Chinese defence minister came to the US on 5 December 1996 for a 10-day visit. He had been in charge as chief of the general staff in 1989 during the Tienanmen incident.(JT 05-12-96) His visit was twice postponed: June 1995 as a result of the visit of the Taiwanese president to the US, March 1996 in connection with the US response to the Chinese missile test-firing.(IHT 03-1296;FEER 12-12-96:26)

The US secretary of state arrived in China on 19 November 1996. The visit was a reflection of a change in US policy: it had downgraded human rights as it sought to mend ties and press a broad agenda. The secretary of state emphasized the need for "a steady and comprehensive approach to the relationship that is not rooted in a single issue".(IHT 20-11-96) He tried to put China and the US on a co-operative course heading to the 21st century. In his speech at Fudan University in Shanghai he said the US intends to remain a Pacific power in the 21st century, so the two states need to get along.(JT 20 and 22-11-96)

On his way to the APEC summit meeting at Manila the US president said, inter alia, that "the US has no interest in containing China". China had accused the US of pursuing a policy of containment (6 AsYIL 396) and had denounced as aggressive a 1996 US-Australian agreement authorizing the largest military exercises of the two countries since World War II.(IHT 21-11-96)

While in Manila for the APEC summit meeting in November 1996 the two presidents agreed to exchange state visits within the next two years. The last presidential visit on either side was the US President's trip to Beijing in February 1989.(JT 25-1196;IHT 25-11-96)

The US vice-president visited China in late March 1997 (IHT 25,27-03-97) and the Chinese foreign minister visited the US in late April 1997.(IHT 29-04-97)

While Sino-US relations were said to have generally improved, disagreements remained.

There were said to be frictions over the treatment of dissidents and over fresh reports of Chinese nuclear sales to Pakistan, although it was maintained by the US that no pledges had been violated with the sale.(AsahiEN 17-10-96)

According to newspaper reports in early November 1996 the two countries were discussing a package of measures intended to defuse tensions over human rights.(JT 02-11-96)

It was reported that after seven months of secret diplomacy a deal was struck between the two countries under which China would sign the two UN human rights covenants, release up to eight political prisoners and restart talks with the ICRC aimed at establishing a program of prison visits (infra) to determine the status of political prisoners.(IHT 24-02-97) By way of reciprocity the US would refrain from sponsoring an annual draft-resolution in the UN condemning China for its human rights record.(IHT 24,28-02-97)

[In six out of the past seven years the US had co-sponsored a resolution calling for an investigation into China's human rights record. However, the draft was every time defeated in the 53-member UN Commission on Human Rights.](IHT 03-03-97) 
In the economic field the US blamed Chinese trade barriers for a worsening trade gap which had surpassed US deficit with Japan.(JT 20-11-96)

Besides, there seemed to be a continuing stalemate in the US efforts to get increased access to the Chinese market due to uncertainties on both sides. While US businesses were eager to enter the Chinese market, the enthousiasm seemed to be tempered by a fear that China might become another Japan, using US technology and guaranteed access to US markets to run up even larger trade deficits, while continuing to limit import of US goods and services through government rulings and unofficial collusion. This would translate for the lower-skilled US worker s into yet another round of job losses and declining wages. For China, any significant market opening would hold the almost certain prospect of throwing millions of Chinese out of work at the inefficient government-owned enterprises that still employed two-thirds of China's urban workers. It could undermine China's efforts to develop advanced industries.(JT 26-11-96)

The US decided in early August 1996 to issue a transit visa to the Taiwanese vicepresident who would be on his way to a presidential inauguration ceremony in the Dominican Republic. US officials said that the granting of a transit visa was in accordance with the one-China policy under which the US continued to maintain 'informal' relations with Taiwan. The Chinese foreign ministry made known its opposition to the stop-over and urged the US "to honour the solemn commitment it has made on the question of Taiwan so as to prevent new damages from occurring in Sino-US relations". China accused Taiwan of using 'transit diplomacy' to increase its international profile.(08 and 13-08-96)

China demanded on 15 August 1996 that the US cancel its plans to sell the Avenger anti-aircraft missile system to Taiwan. A foreign ministry statement said the sale would violate the joint communiques on the US position vis-à-vis Taiwan. On the other hand the US department of state spokesman said that the system was purely defensive and that the sale was consistent with US policy on arms sales to Taiwan.(IHT 16-08-96)

\section{China - ICRC}

In the past China had rejected any outside agency, such as the ICRC, to be given unsupervised access to its prisons. In early March 1997 agreement was reached with the ICRC to resume talks on the issue after a two-year hiatus. The aim was to come to an understanding on the possibility of getting access to political detainees and on the 'standards and conditions' for such visits.(IHT 03-03-97)

\section{China - North Korea}

Marking the 35th anniversary of the Sino-North Korean Treaty of Friendship and Mutual Assistance of 11 July 1961 a Chinese naval flotilla called on a North Korean port for the first time on 10 July 1996.(IHT 11-07-96)

In a sign of improved relations after their co-oling as a result of the establishment of diplomatic links between China and South Korea, China offered 100,000 tons of food to alleviate the famine after the crops failure in North Korea because of the floods of 1996.(IHT 13/14-07-96;FEER 25-07-96 p.13) 


\section{Sanctions against Myanmar}

A citizen of Myanmar who served as honorary consul for Denmark, Norway, Finland, Sweden and Switzerland, was jailed in April 1996 and sentenced to three years, reportedly on charges of possessing two facsimile machines and a telephone switchboard. He died in prison in June 1996, according to Myanmar officials from a stroke and a heart attack. As a result Denmark put the matter of sanctions against Myanmar on the agenda of the EU foreign ministers in July 1996. The Myanmar authorities rejected calls from abroad for an independent autopsy.(IHT 12 and 17-07-96)

\section{Myanmar - US}

The US introduced new visa restrictions barring entry into the US for all members of the Myanmar State Law and Order Restoration Council. According to the White House announcement the measure was aimed at 'ongoing repression' by the military regime.(JT 05-10-96) The measure was reciprocated by Myanmar by restricting visas to certain categories of US citizens.(JT 13-10-96)

\section{Different policies vis-à-vis Myanmar}

The US and the EU were considering economic sanctions intended to make the Myanmar government ease political repression, but ASEAN as well as China and Japan were preferring a policy of 'constructive engagement' rather than isolation in bringing about economic and political change.(IHT 16-07-96)

The ASEAN decision of 20 July 1996 on observer status for Myanmar was critical. It was criticized by the vice-president of the European Commission who warned that acceptance of Myanmar as a full member could jeopardize the EU plan to deepen its relationship with ASEAN. Ministers of ASEAN countries responded by accusing the EU of hypocrisy by comparing the latter's stance toward Myanmar with that on Bosnia and Northern Ireland, while the Indonesia foreign minister said, inter alia: "I do not believe it is appropriate to comment on the internal affairs of an organization where those who are commenting are not even members of the organization".(IHT 1807-96)

At the 'dialogue' meeting on 24 July 1966 Canada and the EU called for a UN 'contact group' made up of Asian and Western states be formed in order to hasten political reform in Myanmar, but the ASEAN members as well as China immediately condemned the proposal ("an absurd proposal put forward to grab headlines back home", "we don't believe in that kind of hypocrisy"). Because of its nature the 24 July meeting was not attended by Myanmar which had only observer status in ASEAN.(IHT 25-07-96)

\section{China - South Korea}

It was reported that relations between the two countries had become less smooth than at the beginning. Mention was made of South Korean annoyance over its exclusion from a projected joint aircraft project, Chinese concern over South Korea's treatment of its ethnic Chinese population who were denied full citizenship and faced discrimination in education, disputes over fishing rights and nautical exclusion zones, 
and South Korean concern over growing numbers of illegal Chinese immigrants.(IHT 14-07-96)

\section{Cambodia - Korea}

Cambodia had been prevented from re-establishing formal relations with South Korea (which were severed in 1975) because of the close relations that existed between the King and North Korea. These relations had developed during the King's years of exile but had soured after the death of KIM IL SUNG: the new leadership had rejected the King's request to visit Pyongyang and lay flowers at the deceased's tomb.

In May 1996 Cambodia and South Korea announced plans to exchange quasidiplomatic missions, and on 14 July the 'Second Prime Minister' visited Seoul where agreements were signed on the protection of foreign investments and the exchange of scientific and technological know-how.(FEER 25-07-96:21)

\section{Japan - Latin America}

The Japanese prime minister went on a tour to Mexico, Chile, Brazil, Peru and Costa Rica, the first such visit since seven years. Japan had invested almost $\$ 60$ billion in the region in the past 14 years, and its economic aid had doubled from 1990 to 1995 to $\$ 1.14$ billion.(IHT 19-08-96)

\section{Japan - Russia}

The foreign ministers of the two countries held a working-level session on a bilateral peace treaty on 2 and 3 October 1996.(JT 26-09-96)

During a regular meeting on 15 November 1996 the foreign ministers of both countries discussed the bilateral territorial dispute over a chain of islands off Hokkaido. The Russian minister suggested that the two countries should jointly develop the disputed islands, and referred to a British-Argentinian arrangement regarding the Falkland Islands. Joint development would not be a substitute for resolving the territorial dispute, but would help improving bilateral relations. Among the concrete problems are the right of Japanese fishing boats to operate in the area, and the possibility for residents of the disputed islands and those of other, Japanese, territory to visit each other's territory without a visa.

The Japanese side stated it would resume economic assistance which was frozen for reasons of political instability in Russia.(IHT 16/17-11-96;FEER 05-12-96:36)

\section{Japan - US}

The US president and the Japanese prime minister met in New York and reaffirmed the need to continue reducing the US military presence in Okinawa (although the US president stressed the need to maintain this presence for stability in Asia), and to resolve trade disputes, with the US raising those regarding civil aviation and (the implementation of a 1994 agreement on) insurance, and Japan raising the issue of the sale of super-computers (see:International economic relations).(JT 26-09-96) 


\section{Japan - China - Korea}

In the context of the Chinese protests against the building of a lighthouse on one of the Senkaku (Diaoyu) islands (see: Territorial disputes) the Chinese foreign minister also criticized the Japanese prime minister's pilgrimage to the Yasukuni shrine in July 1996, classifying it as a return to Japan's 'historic perspective' of justifying its role in the second World War.

The Japanese prime minister said that the July visit was made on his birthday in his private capacity, but in September he nevertheless dropped his plan to visit the shrine again on 16 October, the anniversary of the day on which he was informed of his cousin's death in the war. It was said on 28 September 1996 that the decision was conveyed to the Chinese government through the Chinese embassy.

Mr. HASHIMOTO RYUTARO was the first prime minister to visit Yasukuni since 1985 (prime minister NAKASONE), but he did not visit the shrine on 15 August, the anniversary of the end of World War II, to deflect criticism from South Korea and China.(IHT 16-08-96;JT 26 and 29-09-96)

\section{Cambodia - Thailand}

Cambodia filed an extradition request with Thailand for the arrest and return of five senior Khmer Rouge officials who were suspected to have fled over the border. An extradition treaty applied between the two countries.(IHT 04-10-96)

\section{India - Pakistan}

In her speech to the UN General Assembly the prime minister of Pakistan proposed on 2 October 1996 that Pakistan, India and the major powers convene a conference to resolve the dispute over Kashmir, promote conventional arms control and ease the danger of a nuclear arms race in South Asia.(IHT 04-10-96)

The new prime minister who was elected after the February 1997 elections in his inaugural address offered reconciliation with India, while the Indian prime minister expressed his willingness to resume talks. Earlier talks broke down in January 1994 on the issue of Kashmir.(IHT 18-02-97) Agreement was reached on the resumption of talks on 28 March 1997. A second round was held in April during an NAM meeting in New Delhi (infra p. 464), followed in May by discussions between the prime ministers during a SAARC meeting in the Maldives (infra p.477).

One of the immediate results of the talks in May was the release of civilian prisoners who were being held for offences linked to the hostility between the two countries. Another result was the re-establishment of a 'hot-line' telephone after nearly a decade. [A similar line was set up by the previous summit meeting in July 1989 but was shut down after the then Pakistani prime minister was removed from office the following year.](IHT 13-05-97;FEER 22-05-97:13)

The talks, essentially on normalizing relations, were to be resumed on 19 June 1997 and would include border clashes, the alleged deployment of missiles by India, confidence-building measures, and 'people-to-people contact'.(IHT 14/15-06-97) In a joint statement of 23 June the two sides agreed to explore possible solutions to the Kashmir dispute. This was the first agreement on the matter since 1972 when they agreed to seek a peaceful settlement of the problem. The two sides would meet again in September 1997.(IHT 24-06-97) 
Besides the Kashmir issue the following matters could be subject of Indo-Pakistani discussions: demilitarization of the Siachen glacier in the northern part of Kashmir, defining the western-most border along a 100-kilometre estuary, fishing rights in nearby Arabian Sea waters (rich in prawn and lobster), and expanding trade.(IHT 28$02,07-03,27-03,12-05-97)$

\section{Attitude of neighbouring states toward developments in Afghanistan}

According to reports the US was keen to offset Iranian influence in the region while being torn between supporting Pakistan, which was backing the Taleban, and not antagonizing India and Russia which were sympathetic to the AHMAD SHAH MASUD faction (2 AsYIL 283, 3 AsYIL 342). Iran was allegedly worrying since the Taleban was militantly anti-Shia and might threaten the (Shia) Hazaras in Central Afghanistan. Russia was concerned about a (Pashtun) Taleban movement which might be expansionist, threatening the Central Asian states. India would support the opposition against the Taleban which was a Pakistani creation in Indian eyes, and because the Taleban was strongly anti-Hindu. Pakistan would be the only regional ally of the Taleban. Uzbekistan, which had supported its fellow Uzbek, RASHID DOSTAM (DUSTAM), in the Afghan civil war, was said to fear the Pashtun-fundamentalist Taleban, like the other four Central Asian republics. Turkmenistan had been closely allied to another participant in the Afghan civil war, the (Herat) strongman ISMAEL KHAN, and a significant Turkmen population in Western Afghanistan had historically been victimized by the Pashtuns. Tajikistan had been sympathetic to fellow Tajiks under BURHANUDDIN RABBANI and SHAH MASUD.(FEER 10-10-96:17)

\section{China-Japan-US}

A Chinese spokesman reiterated Chinese concern over the expansion of the USJapanese defence co-operation (see 6 AsYIL 426): "We think that the mutual defence treaty between the US and Japan should deal only with matters concerning the two countries. So what we are concerned about is enlarging the scope of this treaty. ... We consider it inappropriate for the Japanese to expand the coverage of this treaty to territory other than that belonging to Japan."(Daily Yomiuri 10-10-96)

The Japanese prime minister assured the Chinese president during the APEC summit conference in November 1996 (supra p.396) that his government "inherits the war apology issued by the previous prime minister in 1995" (see 6 AsYIL 466), and that Japan's moves to strengthen security ties with the US were not directed at any other country and that Japan did not support the independence of Taiwan. He emphasized that " $[w]$ e only ask for a peaceful solution of the China-Taiwan problem through dialogue".

In the framework of its perception of being the target of an upgraded defence pact between the US and Japan, China launched a diplomatic counter-offensive by arguing that, inter alia, "Asian security should be decided by Asians" and that " $[\mathrm{t}]$ he aim of modifying the guidelines is clearly to expand the scope of Japan-US defence cooperation to cover the whole of the Asia-Pacific region". It was reported that later, during the first half of 1997, China had gone further and had proposed an alternative, consisting of a 'new security concept' that calls for the current US alliances in the 
region to be gradually replaced by bilateral relationships and some form of multilateral security mechanism.(FEER 26-06-97:18)

\section{North Korea - Russia}

The two countries embarked in January 1997 on discussions for a new bilateral treaty to strengthen ties. The 1961 Treaty of Peace and Friendship had become a dead letter since the collapse of the Soviet Union in 1991, and was terminated in September 1996. The new treaty would have no provisions on mutual defence.

A new visa agreement was signed in January 1997. It was reported that previously North Korean migrant workers in Russian territory remained under North Korean jurisdiction, while under the new agreement they would be issued visas to live in a specific place and would register with the local authorities like other foreign residents.(FEER 27-02-97:23)

\section{China - Japan}

After his meeting with the Chinese president at the APEC summit meeting at Manila in November 1996, the Japanese prime minister said that Japan planned to resume the extension of grant aid to China in November 1996. It had suspended the aid in August 1995 in protest over Chinese nuclear tests, the first time Japan had used aid as a political means vis-à-vis China. Since the Chinese declaration of a halt (moratorium) to nuclear testing in July 1996 and its signing of the Comprehensive Test Ban Treaty (supra p. 409), Japan intended to lift the suspension but had refrained from doing so because of China's strong reaction to the incident over the Senkaku lighthouse (infra p. 479). (JT 06-11-96;IHT 25 and 26-11-96) The freeze was finally lifted in late March 1997.(IHT 29/30-03-97)

The re-elected Japanese prime minister pledged that his most important foreign policy task would be to improve bilateral relations with China. In this context he would announce the dispatch of a long delayed survey mission to discuss yen loans for the current fiscal year. Between fiscal 1996 and 1998580 billion yen would be provided to China.(JT 20-11-96) The mission visited China in late November 1996.(JT 26-11-96)

Meanwhile a policy guideline had been drafted in the Liberal Democratic Party of Japan which was expected to be adopted as an official party platform, and which calls for a review of Japan's economic assistance policy toward China. It envisaged that the extension of yen loans to China may be coming to an end now that the Chinese economy was on a path of development. Specifically, the guideline prescribed that in extending official development assistance to China, the government must stick to the principle of not extending ODA to a country that lacks progress in democratization or has an unjustified large military budget.(JT 29-11-96)

\section{Japan - France}

The two countries signed a far-reaching bilateral agreement on 18 November 1996, covering diverse subjects such as increased co-operation in space research and the holding of annual summit meetings and regular meetings of foreign ministers.(IHT 19-11-96) 


\section{South Korea -Vietnam}

The South Korean president paid a visit to Vietnam in November 1996, the first South Korean leader to do so four years after the establishment of official relations. The two countries fought on opposite sides in the Vietnam War. Relations between South Korea and (then) South Vietnam were cut in 1975. (IHT 21-11-96;AsahiEN 2111-96)

\section{South Korea - Japan}

The Japanese prime minister and the South Korean president agreed on 24 November 1996 at the APEC summit at Manila to meet in Japan early 1997 to exchange views on the future course of bilateral relations.(JT 25-11-96)

Meanwhile a policy guideline, expected to be adopted as an official party platform of the Liberal Democratic Party of Japan, stressed the need to build bilateral relations while paying due attention to the feelings of the South Korean people concerning Japan's colonial rule of the peninsula from 1910 to 1945 and Japan's wartime behaviour.

The guideline proposed expanding economic relations between Japan and North Korea and opening diplomatic relations between the two countries at an early date.

Concerning Takeshima Island (infra p.482) the guideline stressed that the island is Japanese territory.(JT 29-11-96)

\section{China - India}

The Chinese president made the first ever Chinese state visit to India from 28 till 30 November 1996. The visit was aimed at easing tensions with India.(JT 29-11-96) [Relations between the two countries were severed in 1962 and restored in 1976. Since then Indian prime ministers visited China in 1988 and 1993.](IHT 30-11/01-1296)

During the visit four agreements were initialed: one on confidence-building measures minimizing the possibility of armed conflict on the common borders ('line of actual control'), a second on direct shipping links, a third on the establishment of an Indian consulate in Hongkong after mid-1997, and a fourth one on preventing illegal drug trafficking.(JT 30-11-96) The first agreement would advance an agreement signed in 1993 in Beijing by the Indian prime minister (see 4 AsYIL 417). Since this latter agreement tensions between the two countries had eased while bilateral trade had increased sharply.(IHT 28-11-96) Specifics on the timetable for withdrawals as well as the number of troops to be moved back from the lines of actual control would be decided later after further bilateral discussions.(FEER 12-12-96:16)

\section{China - Pakistan}

The Chinese president came to Pakistan for a four-day state visit on 1 December 1996. He emphasized that the co-operation in the use of nuclear energy for peaceful purposes would be continued despite outside concerns that China had supplied technology for nuclear weapons.(IHT 01-12-96;JT 02-12-96) 


\section{Cambodia - Vietnam}

More than two dozen members of a group allegedly advocating the overthrow of the Vietnamese government were arrested in Cambodia. The group was believed to be connected with Vietnam Tudo, or Free Vietnam, an underground movement that was believed to have operated in Cambodia since 1994.It was said that almost all were Cambodian-Vietnamese and ethnic Vietnamese.(JT 03-12-96)

\section{Chinese state visit to Nepal}

After his visits to India and Pakistan the Chinese president paid a two-day state visit to Nepal from 4 December 1996. This was the first visit by a Chinese president in 12 years.(JT 05-12-96)

\section{China - Vatican}

China responded on 5 December 1996 to an appeal from the Roman Catholic Pope to allow the Chinese Roman Catholics to have official links with the Vatican. It said it wanted better relations with the Vatican but would brook no interference in China's internal affairs.

China maintained relations with the Vatican until 1957, when the Pope excommunicated two Chinese bishops appointed by the Chinese authorities. China then severed ties with the Vatican, which set up relations with the government at Taipei. As a condition for improved relations China required severance of relations with Taiwan and recognition of the Beijing government as the sole legal government of China including Taiwan.(IHT 06-12-96;AsahiEN 06-12-96)

\section{Chinese high-level visit to South Korea}

A Chinese military delegation visited South Korea, being the highest-level visit since the two countries which fought each other in the Korean War established relations in 1992.(JT 08-12-96)

\section{Iran - Turkey}

The president of Iran visited Turkey, beginning 19 December 1996, reciprocating the visit by the Turkish prime minister in August 1996. During the earlier visit an agreement was signed for the supply of Iranian natural gas, while the recent visit was used for the discussion of a study on the construction of a pipeline to carry Iranian oil to the Turkish Mediterranean terminal of Ceyhan. Besides several other trade agreements were concluded, such as mutual grant of most-favoured nation status, encouraging and promoting of mutual investment, outlining new co-operation in maritime trade, and establishment of a joint Chamber of commerce.

It was reported that the visit antagonized the US which is trying to isolate Iran. A state department's spokesman said: "We strongly advise the Turkish government not to improve its relationship with Iran".(IHT 20 and 23-12-96)

China - Russia

(see also: Borders) 
The Chinese prime minister visited Russia in late December 1996.(IHT 28/29-1296) An agreement was signed on the purchase of two destroyers. On his return the prime minister referred to a 'strategic partnership' between the two countries which would help offset the influence of the US as the world's only remaining superpower.(IHT 20-01-97) A mutual commitment was earlier established at the summit meeting of April 1996 (see 6 AsYIL 406).

A summit meeting took place on the occasion of the visit by the Chinese president to Russia on 22-26 April 1997.(IHT 23-04-97) The two presidents on 23 April signed a "Declaration on a Multipolar World and Formation of a New World Order" to counterbalance US power. The Declaration called for a greater peace-keeping role for the UN, a strengthened UN Security Council, and a new conception of international security. It recommended that peace-keeping operations be carried out only with the Security Council's consent and only with the agreement of the countries involved, in strict accord with the Security Council's mandate.

Other issues dealt with at the summit were the promotion of trade and investments, twice-yearly meetings of prime ministers, the development of projects in various fields.(IHT 24-04,25-04-97;FEER 08-05-97:16)

\section{Japan - Southeast Asia}

The Japanese prime minister visited five Southeast Asian countries (Brunei, Malaysia, Indonesia, Vietnam, Singapore) in early January 1997 after having been to Thailand and the Philippines in 1996.(IHT 08-01-97) During his visit the Japanese premier proposed summit meetings at least once a year to deepen ties. In a speech held on 14 January 1997 in Singapore, described by Japanese officials as an important new statement of Japanese policy toward Asia (so-called 'Hashimoto Doctrine'), he proposed a wide-ranging partnership that would extend Japan's relations with Southeast Asian countries beyond economic ties into high-level political and security cooperation.(IHT 14,15-01-97) It was reported that the response was 'lukewarm' out of fear of a more assertive Japan and the possible complications of the regional balance of power resulting from a new approach. The Japanese initiative would imply an emphasis on bilateral links, while ASEAN appeared to prefer a multilateral context.(FEER 30-01-97:14)

\section{Asia-Europe Foreign Ministers Meeting}

The first meeting of Asian and European foreign ministers took place on 15 February 1997.(IHT 04-02-97)

\section{Iran - Russia - US}

The US issued a diplomatic warning to Russia about alleged Russian assistance to Iran's missile program, which could potentially threaten US troops in Saudi Arabia, several US allies in the Gulf, and Israel. The allegations referred to transfer of technology on the Russian SS-4 missile with a range of 2,000 kilometres. The Russian prime minister denied that his government had authorized such transfer.(IHT 13-0297) 


\section{Pakistan - Russia -- Ukraine - India}

Russia tried to stop the sale of tanks from Ukraine to Pakistan, by banning the export of guns and targeting systems for the Russian-designed tanks. The sale may offend India with which Russia traditionally had friendly relations.(FEER 06-0397:13)

\section{Malaysia - Singapore}

In an affidavit filed in a court case the Singapore senior minister and the deputy prime minister referred to the Malaysian state of Johore as being "notorious for shootings, muggings and carjackings. ... It did not make any sense for a person who claims to be fearful for his life to go to a place like Johore". [The case concerned a law suit by the ministers against an opposition politician who had fled to Johore in Malaysia after allegedly receiving threats.]

In an unusually strong protest, Malaysia asked the senior minister to apologize and retract his statement.(IHT 13-03-97) The apology was given 'unreservedly' on 13 March 1997: "The senior minister had no intention to cause offense and apologizes unreservedly for the offense he has caused to the government and people of Malaysia by his statement on Johor."(IHT 14-03-97) When this apology did little to ease Malaysian tempers, the senior minister made a second statement some days later, telling that he had asked the court to have the offending paragraphs deleted from the affidavit. In granting the request, the High Court judge said: "The powers of the court must be used to maintain friendly relations between Singapore and every other country". Two days later the Malaysian cabinet accepted the apology.(IHT 20-03,29-0497;FEER 27-03-97:16)

No similar request was made by the deputy prime minister. It was reported that for this and other reasons referred to by Malaysian officials as "lack of sincerity in the behaviour of other Singapore leaders", Malaysia would temporarily freeze official ties with Singapore but these reports were later played down by a statement that no decision had been taken.(IHT 27-03,28-03-97)

\section{US forces in the Asian region}

US officials in March 1997 gave assurances that the US presence would not be reduced and that there were strong reasons for keeping the US forces at current levels of about 100,000 men. It was reported that the American forces were regarded as a key counterweight to the emerging power of China and a deterrent to the rearmament of Japan with offensive weapons.(IHT 17-03-97)

\section{Vietnam - US}

The US finance secretary visited Vietnam in early April 1997, being the highest ranking US economics official to visit the country since the end of the Vietnam War. He signed a debt-rescheduling agreement under which Vietnam agreed to pay back debts incurred by the former South Vietnamese government.

Vietnam asked the US to waive its so-called 'Jackson-Vanick amendment' under which most-favoured nation status was blocked for Communist countries that deny their citizens the right to emigrate.(IHT 07-04,08-04-97) 


\section{India - Afghanistan}

India as the host state had invited the president of Afghanistan to attend the NonAligned Movement conference held in New Delhi in early April 1997 (infra p.464), despite the fact that he was in fact already ousted by the Taleban movement. Member states of the NAM had not yet given formal recognition to the Taleban government. India had abandoned its embassy in Kabul the day before the Taleban took control of the capital in September 1996.

The Taleban information minister said that "the Indian government [had] insulted the Afghan people".(AsT 08-04-97)

\section{Iran-Europe relations}

After the verdict of the Berlin court of 10 April 1997 in the so-called Mykonos case (see: Jurisdiction) the member states of the European Union recalled their ambassadors from Tehran, thus suspending the EU's 'critical dialogue' with Iran. A similar recall took place eight years ago after the verdict against the British author RUSHDIE for blasphemy.(NRC 11-04-97)

\section{China - EU}

The Taiwanese foreign minister addressed a committee of the European Parliament on 22 May 1997, despite sharp protests from the Chinese government. The chairman of the committee had specified before that the speech was part of an 'information meeting' that did not constitute a recognition.(IHT 23-05-97)

\section{Japanese women living in North Korea}

Japan rejected a North Korean offer of approving home visits by Japanese women in exchange of one million tons of rice. The women in question had married ethnic Koreans in Japan and had left Japan for North Korea, mostly in the 1950s and 1960s.(IHT 24/25-05-97)

\section{Philippines - Singapore}

During a postponed visit by the prime minister of Singapore to the Philippines the two states concluded a series of agreements on 10 June 1997 aimed at improving relations. These were strained as a result of the so-called FLOR CONTEMPLACION case in 1994 (see 5 AsYIL 400).(IHT 11-06-97)

\section{Iran - US}

During a five-country Gulf tour the US defence secretary stressed at each stop that Iran posed a danger to its militarily weaker neighbours and did not deserve to be invited as a full member of the world community. He said at a news conference that Iran "continues to support terrorism in addition to developing weapons of mass destruction, improving missiles that can strike neighbouring nations and boosting the facility to close the Strait of Hormuz". With reference to these allegations he said: "The US will not allow this to happen".(IHT 18-06-97) 


\section{(NON-)INTERFERENCE}

See also: Arms sales and supplies, Association of South East Asian nations, Civil war, Dissidents, Inter-state relations (Myanmar, China-Australia, China-Vatican)

\section{Thailand on dialogue between government and opposition in Myanmar}

The Thai foreign minister, urging a dialogue, said: "We would, of course, encourage any dialogue that would lead to stability and peace, but we would not go out of our way in any way that could be perceived as interference".(IHT 09-07-96)

\section{Dalai Lama in the UK}

The Chinese foreign ministry protested against the scheduled visit by the Dalai Lama to the British parliament in mid-July 1996: “Tibetan affairs are purely Chinese affairs, which brook no interference by any foreign government organizations or individuals." By offering the spiritual leader a forum Britain "is supporting and abetting the Dalai Lama's activities to split the motherland".(IHT 09-07-96)

While in Britain the Dalai Lama called for a concerted international effort to pressure China to improve human rights in Tibet and to start negotiations with his government in exile.(IHT 17-07-96)

\section{China - Australia}

China threatened Australia with commercial and economic sanctions over meetings between the Australian foreign minister and the Dalai Lama. Nevertheless the Australian prime minister did meet the Dalai Lama as a 'significant religious leader'. The Chinese foreign ministry said that the meeting represented "an interference in China's internal affairs" and rejected the description of the Dalai Lama as a religious leader.(IHT 20 and 25-09-96;JT 26 and 27-09-96)

\section{China - Germany}

Expressing of its displeasure over a German parliamentary resolution in June 1996 on Tibet (see 6 AsYIL 456) China withdrew an invitation to the German foreign minister for a visit to China in July 1996. The incident was ended by a meeting between the two foreign ministers in September during the UN General Assembly meeting, and the invitation was renewed in late September, together with an invitation to the German president. The German foreign minister stressed the German position that Tibet is part of the Chinese state. He started his visit on 21 October.(IHT 26-09-96,22-1096)

\section{Dalai Lama meetings in France}

The Dalai lama met members of the French legislature during his visit to France late October 1996, and had an informal 'spiritual' meeting with the minister of justice.(IHT 30-10-96; JT 01-11-96)

\section{US involvement in Sino-Japanese island dispute}

China warned the US on 15 October 1996 not to intervene in the dispute between China and Japan over the Diaoyu (Senkaku) islands. The statement was given in reac- 
tion to a US Congressional report that urged the US government to defend the islands on the basis of a new security arrangement between the US and Japan concluded in April 1996.(AsahiEN 16-10-96;JT 17-10-96)

\section{Indo-Iranian attitude toward the civil war in Afghanistan}

During a visit of the Iranian foreign minister to India the two countries on 17 October 1996 urged the warring factions in Afghanistan to end their civil war and called on neighbouring countries to use their influence to help work out a solution. The Indian minister also said that both countries wanted an end to 'outside involvement': "The problem of Afghanistan should be left to the Afghan people. All parties in Afghanistan should get together and should solve the problems of Afghanistan peacefully." The Iranian minister said that "any kind of foreign intervention will deteriorate the situation".(IHT 18-10-96)

\section{Conference on East Timor banned in Malaysia}

The Malaysian government said on 7 November 1996 that it would block human rights groups from holding a planned conference on East Timor in Kuala Lumpur. It would seek all legal avenues to prevent the conference. The deputy prime minister said: "Malaysia should not interfere with Indonesia's domestic problems." A number of foreigners who had come to Malaysia to attend the conference were later deported.(IHT 08 and 12-11-96)

\section{China - Vatican}

China responded to an appeal from the Pope to legalize the Roman Catholic Church by saying that it wanted better relations with the Vatican but would not allow interference in its internal affairs. The foreign ministry's spokesman said: "The Vatican must ... stop interfering in China's internal affairs, including using religion ..." China also demands the severance of relations between the Vatican and Taiwan.(JT 06-12-96)

\section{US criticism of Singapore elections campaign tactics}

The prime minister of Singapore strongly rejected a comment by the US state department criticizing the elections campaign tactics of the ruling party in Singapore. The Singapore foreign ministry called the comments "undisguised interference in Singapore's domestic politics".(IHT 27-12-96)

\section{INTERNATIONAL ECONOMIC RELATIONS AND TRADE}

See also: World Trade Organization

\section{World Semiconductor Council}

The 1991 Japanese-US semiconductor arrangement, created with the aim of opening Japan's chip-market to foreign companies, was to expire on 31 July 1996 (see 6 AsYIL 413). The US initially preferred a 'transitional' bilateral agreement to re- 
place it instead of a World Semiconductor Council including Europe, as proposed by the Japanese and endorsed by the EU in July 1996.(IHT 10-07-96)

On 2 August 1996, however, the two governments agreed that the 1991 agreement would be succeeded in March 1997 by a World Semiconductor Council, an industrylevel multilateral forum that would be operated in line with the WTO rules. The council would extend membership only to industry groups whose governments had abolished or pledged to repeal chip tariffs. A first preparatory meeting was held in October 1996 by Japanese and US industries.(IHT 3/4-08-96;JT 10-10-96)

Since the production was no more restricted to the US and Japan, and since a substantially bigger part of the Japanese chipmarket was supplied by foreign manufacturers, the US-Japanese dispute had in fact lost much of its importance.(IHT 06-0896)

\section{Japan-US dispute on Japanese insurance market}

The dispute centred on the implementation of a 1994 bilateral agreement. The US accused Japan of reneging on the agreement by preparing to deregulate the so-called third sector of its insurance market (covering sickness, accident, nursing care and other products falling into a gray zone between the primary life and non-life insurance sectors) in which foreign firms already had a strong foothold and preferred no new competition, while deferring the opening of the primary life and casualty insurance markets.

Parties failed to reach agreement during a ministerial meeting at the end of September 1996. Following this meeting Japan withdrew its proposal to deregulate automobile insurance premiums as part of the liberalization of the country's primary insurance sector. Talks were resumed on 15 November with a self-imposed December 15 deadline. These talks were not successful.(IHT 29-07-96,26-09-96; JT 01-1096,17-11 and 20-11-96)

In early December 1996 the Japanese side decided to propose the abolition in 1999 of restrictions on the entry by Japanese newcomers into the third-sector insurance market, paving the way for non-life insurance subsidiaries of Japanese life insurers to enter the market dealing with personal accident coverage. This sector was a major source of earnings for US insurance companies and the US had consequently insisted that removal of the market entry restrictions should take place in 2001 at the earliest. The 1994 Japan-US insurance agreement called for the avoidance of 'radical change' in the third sector for a 'reasonable period' after life and non-life insurers were allowed to enter each other's field in Japan.

The US hinted at sanctions in case of failure of the talks, and on the Japanese side there were hints that the issue would be taken to the WTO in case of failure.(JT 0812-96) Unless more liberalization in Japan's life and non-life insurance market were secured, the US would remain opposed to Japanese subsidiaries handling certain products in the so-called third sector.(JT 12-12-96)

The two countries finally reached agreement on 14 December 1996 with Japan pledging to undertake sweeping deregulation of its non-life insurance market, such as automobile- and fire insurance, phased in over two years. The deregulation aimed at eliminating the rate-setting power of insurance councils. Before the agreement was 
reached, the US had spelled out the type of economic penalties Japan would face had no agreement been reached.

The Japanese insurance market is the second largest in the world after the US.(JT 15-12-96; AsahiEN 16-12-96)

On the so-called third sector, non-life subsidiaries of domestic life insurers would be able to sell personal accident insurance as of 1 January 1997, but special measures would be taken to avoid 'radical change' in the market.(JT 17-12-96)

\section{US trade deficit with China and Japan}

In June 1996 the US trade deficit with China had exceeded that with Japan for the first time. While the US trade gap with Japan showed a declining trend, that with China was increasing. On the other hand, the Chinese market was more open to investment and imports than Japan's.(IHT 22-09-96)

Later Japan's trade surplus increased again as a result of the decline in the value of the yen. During a visit by the Japanese prime minister to the US in late April 1997, the two countries agreed on the need to avert such increase and on stepping up talks on deregulating the Japanese economy under the 1993 framework agreement (see 4 AsYIL 468).(IHT 26/27-04-97)

\section{Phase-out of Multifibre Arrangement and imposition of EU anti-dumping duties on Asian textiles}

While Asian countries worried about a proper implementation of the phase-out of the Multifibre Arrangement (see 6 AsYIL 414) the EU planned to impose antidumping duties on import of Asian textiles in 1996. In view of the existing quota system, the anti-dumping fines constituted an additional discrimination.

By way of illustration reference is made to the anti-dumping procedure concerning exports of unbleached cotton from China, India, Indonesia and Pakistan. The EU imposed provisional duties up to $36 \%$ for five years on complaints in November 1996 from Eurocotton, representing the interests of European cotton manufacturers. After further investigation the EU Commission recommended a duty of $19 \%$. In view of objections from European users of unbleached cotton (including dyers, fabric printers, home-furnishers and clothing manufacturers) Britain and Germany and six other EU countries voted against the fines, while France had backed the anti-dumping proposals in view of the interests of the French cotton-producing and weaving sector.(FEER 0310-96:100)

\section{EU anti-dumping policies}

The WTO allows its members to raise import prices by imposing anti-dumping fines when there is proof that the low import prices, resulting from being lower than the cost of production, hurt domestic industry.

Asian exporters complain that the EU is using anti-dumping instruments to keep out low-cost Asian exports, even when there is no proof of dumping or damage to European producers, thus using anti-dumping as a substitute form of trade barrier. Besides the frequency of the anti-dumping actions, it was argued that the methods for determining injury to domestic industry and calculating dumping margins before imposing the fines are flawed. Further, it was contended that the interests of European 
manufacturers were granted priority over other European economic players. In contrast to these policies the EU continued moves to liberalize imports from Eastern Europe, North African countries and Turkey.(FEER 03-10-96:100,12-06-97:68)

The procedure for determining dumping is also considered unfavourable for Asian exporters. While the European manufacturers have plenty time to gather incriminating data against exporters, the latter have about a month only to provide details on prices and production costs. Besides they have to employ expensive anti-dumping lawyers in Brussels who are familiar with the system.

It was said that future WTO agreement on harmonizing international-competition rules, including guidelines on curbing industrial subsidies, might prevent European arguments about the use of government funds to keep export prices deliberately low.(FEER 12-06-97:68)

\section{Mutual demands for deregulation}

The US made demands to Japan on deregulation in 14 areas, including a ban on holding companies, easing standards for mergers and acquisitions, allowing foreign access to Japan's satellite business, liberalization of the pension funds market, and further administrative reforms. It requested these topics to be reflected in the planned new Japanese deregulatory package to be relased in March 1997.

The requests, the third comprehensive package of its kind since 1994, also reflected US concern over intransparency of Japan's bureaucracy resulting from connections between private and public sectors through former senior bureaucrats transferring to companies on their retirement in the 'amakudari' practice.(JT 16-11-96)

On its part, Japan put forward the lack of a system for accepting foreign lawyers in some US states, maritime transport regulations and tariffs on medical equipment.(AsahiEN 21-11-96)

\section{G-15 attitude on international economic relations}

The Group of 15 (G-15) countries held a trade promotion summit conference in Harare early November 1996. They accused the industrialized states of an expansive interpretation of the WTO rules and of pressing internationally binding trade arrangements under the WTO which erode their sovereignty.

The Malaysian prime minister criticised the enactment of extraterritorial laws to which everybody was to submit, referring to US threat of sanctions against Malaysian investment in an Iranian oil exploration project. The Malaysian share was 30 percent in the $\$ 600$ million project, thus exceeding the $\$ 40$ million per year level fixed by US law for investment by non-US firms in Iranian and Libyan oil and gas sectors (infra p.474). The prime minister also said that the promotion of social clauses by the West were aimed at negating the advantage of cheap labour in developing countries, and that globalization of trade was being used to impede developing countries.(JT 05-1196)

\section{Sino-Japanese textile trade}

China and Japan agreed on measures to check soaring Chinese cotton textile exports to Japan. Under the accord China would strengthen controls by establishing quotas for cotton textile exports to Japan. The 1999 level of Japan-bound exports as 
measured by Chinese customs statistics is expected to equal the average annual figure for four to five years through 1996.

The dispute broke out in July 1996 when the Japan Spinners Association and the Japan Cotton and Staple Fiber Wearers Association filed for a so-called 'safeguard' curb to limit surging imports from China. The Japanese government began investigations in August to study the possibility of invoking the curb, which is allowed by the WTO Textile Agreement to be imposed as a temporary step to protect domestic industries. The WTO Agreement primarily calls for trade control by exporting countries.(AsahiEN 07-11-96)

\section{Chinese retaliation to US penalty for alleged textile trade violations}

The US had introduced new rules on the import of textiles and garments as of 1 July 1996. Under the rules, the origin for garments is the country where the cloth is cut rather than where it is sewn; for fabrics, it is the country where the material is made rather than finished.

In early September 1996 the US penalized China \$19 million for allegedly attempting to circumvent quotas on its textile exports to the US by shipping more than 2 million garments through seven other countries (mislabeling and transshipment). China, which controlled $8 \%$ of the US textile market, denied the accusation, on its part accusing the US that the latter had not provided evidence and had not consulted China before applying sanctions, thus violating the 1994 textile agreement between the two countries. By way of retaliation, China announced a temporary ban on the import of a number of US goods, but later decided to delay the ban due to plans for further talks and to a pledge by the US to review the issue.

In early December the two parties broke off talks on the textile dispute but decided to resume them later in the month. On 2 February 1997 an agreement was finally reached, extending the 1994 agreement for four years.(IHT 09-09-96,11 and 12-1196,09-12-96,1/2 and 3-02-97;JT 12-11-96,07 and 10-12-96;FEER 22-08-96:71,19-1296:75, 13-02-97:57)

\section{International trade of Least Developed Countries}

The Secretary General of the WTO had proposed a plan in June 1996 aiming at improving market access for these countries by eliminating all tariff and non-tariff barriers on their exports. The category of Least Developed Countries (LDC) refers to 48 countries classified as such for having an average per capita income of less than $\$ 320$ a year. Twenty-nine LDCs are WTO members, among which is Bangladesh. The plan could only succeed, however, if other developing countries not belonging to the category would accept the risk of their manufacturing capacity being moved to LDC countries.(IHT 10-12-96)

\section{Japanese-US conflict on treatment of foreign shipping companies}

The US Federal Maritime Commission had accused Japan of unfair treatment of foreign shipping companies in Japanese harbours resulting from discriminatory practices by the Japan Harbor Transportation Association. The Commission threatened to retaliate by imposing penalties of up to $\$ 100,000$ for each Japanese vessel calling at 
US ports. Thereupon Japanese officials hinted that in that case Japanese shipping might unload their cargo in Canada instead of in US ports.(IHT 22/23-02-97)

\section{US demand for a 'fair share' of Chinese government procurement}

It was reported in early March 1997 that the US government handed a list of 20 Chinese infrastructure projects to the Chinese government and asked that specific US firms be chosen to build them. The choice of US firms would give them a fair share and would help ease the effects of the widening US trade gap with China.(FEER 1303-97:63)

\section{Revocation of Myanmar eligibility for GSP}

The EU decided to strip Myanmar of special trading privileges in response to concerns over its human rights record. This implied the loss of eligibility for trade benefits under the Generalized System of Preferences.(IHT 22/23-03-97)

\section{Japanese report on international trade}

In the sixth annual report of the Japanese ministry of international trade and industry (MITI) on the practices of Japan's biggest trading partners, it was said that "[a]ll countries, to some extent, employ trade policies and measures that fail to conform to international norms".

The report attacked the US over, inter alia, continuing import restrictions on yellow-fin tuna and shrimp, but said it was improving in the area of anti-dumping duties. By contrast, the EU anti-dumping policies were considered to have become less transparent: the EU was allegedly increasingly using discretionary powers to impose duties in violation of WTO rules.(IHT 01:04-97)

\section{Iran-German/Europe trade}

It was reported that high debts and political differences had begun to strain economic ties between the two countries. German exports to Iran in 1996 amounted to $\$ 1.3$ billion (down from $\$ 8$ billion five years earlier), as against $\$ 1.1$ billion in German imports from Iran. Exports to Iran had fallen sharply because of Iran's foreign debt of about $\$ 22$ billion at the end of 1996.

Iran had a trade surplus of $\$ 1$ billion with the European Union as a whole, exporting $\$ 6.1$ billion worth of goods and importing 5.1 billion worth.(IHT 11-04-97)

\section{China's most-favoured nation status in the US}

The US president on 19 May 1997 announced his intention to renew China's MFN-status for the following year. The US Congress had 30 days in which to act on his recommendation or seek to overturn it, but the president said that he would veto a rejection by the Congress.(IHT 20-05-97) On 24 June 1997 the US House of Representatives approved the one-year extension.(IHT 25-06-97) China welcomed the vote and reiterated a call for permanent most-favoured nation status.(IHT 26-06-97) 


\section{Phase-out of Indian import barriers}

The EU threatened to sue India before the WTO if it would not act quicker in implementing the phase-out of over 2,700 import barriers. The EU, the US and Canada argued that India was no more justified to maintain quotas on balance-of-payments grounds and that it must dismantle the barriers in the next two years. India, however, held the opinion that it needed nine years.(FEER 26-06-97:73)

\section{JAPAN'S MILITARY ROLE}

\section{Increased deployment of Japanese military forces}

During the Gulf (Iraq) War Japan provided its allies with money but not with personnel. Since 1991, however, Japan had participated in UN peacekeeping operations in Cambodia, Zaire, Mozambique and the Golan Heights.

In 1996 Japan indicated it may be willing to contribute funds to a US-proposed African Crisis Response Force. The US made the proposal to the Organization of African Unity on 10 October 1996. All the Force's missions would have to be authorized by the UN. The US indicated its willingness to put up half of the amount needed in the initial stage and was looking to European countries and Japan to bear the rest.(FEER 19-09-96:16;JT 13-10-96)

\section{JOINT DEVELOPMENT AND JOINT VENTURES}

See also: Foreign investment (Myanmar), Oil and gas

\section{Trans-ASEAN Gas Pipe System}

It was reported that ASEAN contemplated a regional gas-transmission system linking the (then) seven member states.

The only existing international gas pipeline was the one providing Singapore with gas from the east coast of peninsular Malaysia under a 15-year contract that was to expire in 2007. Thailand and Myanmar had signed an agreement to pipe gas from Myanmarese gas fields in the Gulf of Martaban to the shore and then overland to Thailand (supra p.423). The Indonesian Natuna gas field is scheduled to begin shipments of liquefied natural gas to Japan, Korea and Taiwan by 2005.(IHT 05-07-96)

It was reported that the Indonesian state oil company Pertamina and the Petroleum Authority of Thailand (PTT) had agreed on 21 August 1996 to proceed with discussions on the feasibility of a natural gas pipeline between the Natuna gasfield and the Thai maritime border, a distance of about 800-900 kilometre. Thailand would then pump it a further 200 kilometre to the mainland. While Pertamina would not be able to compete with other suppliers nearer Thailand on price, it could offer security of long-term gas supply.(ST 13-09-96;FEER 12-09-96:54-55,24-10-96:70;JT 19-11-96)

\section{Iranian refinery in Pakistan}

It was reported that Iran agreed to build a $\$ 1.2$ billion crude-oil refinery in the southwestern Pakistani province of Baluchistan. It was said that the two countries also 
agreed to conduct a feasibility study for a $\$ 3.5$ billion natural-gas pipeline.(FEER 2908-96:65)

\section{Iranian petrochemical plant}

Iran announced on 8 October 1996 that it had reached agreement with a Dubaibased consortium of German and South Korean companies to build a $\$ 600$ million petro-chemical plant at Kermanshah, $650 \mathrm{~km}$ west of Tehran. The plant would fall under a buy-back scheme.(AsahiEN 09-10-96)

\section{Kazakh-Iranian oil co-operation} (see also: Oil and gas)

It was disclosed in August 1996 that Iran and Kazakhstan had concluded an agreement, under which Kazakhstan would export oil for use in Iran while Iran would export Iranian oil under a Kazakhstan label. The Kazakh export would start in November 1996. It was estimated that Kazakhstan would export 14 million barrels annually through Iran, possibly reaching 42 million barrels in a decade. It has reserves of more than 14 billion barrels.

Kazakh oil fields are on the Caspian Sea but the best transport routes to customers are through the Persian Gulf.(JT 05-11-96)

\section{Pipelines for the transport of Kazakh oil} (see also: 3 AsYIL 380,434; 6 AsYIL 420)

Kazakhstan, Russia and Oman reached agreement on the building of a pipeline connecting the Tengiz oil fields with a port to be built on the Black Sea. The final agreement including the three states and eight oil companies was finally signed on 16 May 1997. Construction would start in 1998 and be completed in about two years.(IHT 20-11-96,17/18-05-97)

\section{The Nam Theun-2 hydropower project in Laos}

The 900-megawatt project, to be carried out on the Nam Theun River, was proposed by the Nam Theun-2 Electricity Consortium (NTEC) consisting of Transfield construction company of Australia, Electricité de France, Italian-Thai Development, Thai telecoms firm Jasmine International and another Thai financier. The government had given its approval in principle in 1993 and would hold a quarter share in the project.

The implementation of the project was stemmed by protests from some environmentalist movements, although other organizations in the same field disagreed and even supported the plans.

According to the Lao government the project is crucial to Laos's bid to catch up with the booming economies of other Southeast Asian countries. It insisted that Laos had no choice but to build hydroelectric stations and sell power to its wealthier neighbours, particularly Thailand. In July 1996 Laos also reached an agreement with Vietnam to sell electricity from two proposed facilities in southern Xekong province.(FEER 13-02-97:48) 


\section{JUDICIAL ASSISTANCE}

\section{The Bofors arms case}

The case stemmed from a $\$ 1.3$ billion arms deal in 1986 between India and Bofors arms manufacturers of Sweden. The Indian government had been trying to find out whether leading Indian politicians had received bribes in connection with the deal. After it was established that Bofors had paid millions of dollars into Swiss bank accounts, India asked Switzerland to provide details. After seven years the Swiss Supreme Court ruled on 26 November 1996 allowing the government to grant the Indian request. The government accordingly decided to hand over secret bank documents to India. These were handed over to the Indian ambassador on 21 January 1997.(IHT 1601-97)

\section{JURISDICTION}

See also: Inter-state relations (North Korea-Russia), International economic relations (G-15)

\section{German court verdict on Iranian involvement in crimes}

In the so-called Mykonos case (see 6 AsYIL 422) the German public prosecutor had asked the court for a life sentence for two Iranians, among whom an alleged intelligence official. He had also accused the religious leader of Iran and its president of complicity in the crimes. The Berlin District Court on 10 April 1997 pronounced its verdict in which it held that Iranian government organs and "the highest authorities of the Iranian state" were actively involved in the killing of the four persons by planning, directing and preparing the attempt. The verdict said that the killings were based on an assassination decree issued by the Committee for Special Operations. Of the five defendants, an Iranian and four Lebanese, two were sentenced to life-long imprisonment, two others received long prison sentences and one was acquitted.(IHT 1104,12/13-04,18-04,29-04-97)

A warrant was issued in 1996 for the Iranian intelligence minister on suspicion of ordering the killing. After the court decision further arrest warrants were issued for 3 Iranian secret service officials, but the German public prosecutor decided not to take legal action against other Iranian leaders who were judged to be implicated in the assassination.(IHT 16-05-97)

In a letter sent to foreign ambassadors in Tehran the Iranian foreign minister described the German court decision as 'biased and illegal', and characterizing it as "more like a political manifesto than a legal document".(IHT 17-04-97) Demonstrations were held outside the German embassy in Tehran while hundreds of policemen shielded the compound.(IHT 19/20-04-97)

On 29 April 1997 the EU endorsed a declaration calling on Iran to respect international law and renounce terrorism. It reaffirmed the suspension of its 'critical dialogue' with Iran, and maintained a long-standing European embargo on arms sales to Iran. The EU decision committed EU governments to co-operate in ensuring that visas were not granted to Iranian intelligence agents, and to work together to exclude intelligence agents from Iranian embassies in Europe.(IHT 29-04,30-04-97) 


\section{No FBI office in Beijing}

China refused approval to the US to open an office of the US Federal Bureau of Investigation in Beijing.(IHT 11-04-97)

\section{Pakistani citizen employed by US Drug Enforcement Agency}

Pakistan rejected a US demand for the release of a detained local employee of the US DEA because the man was a Pakistani citizen and consequently fell under Pakistani jurisdiction. The man was accused of "involvement in drug trafficking and antistate activities".(IHT 16-05-97)

\section{KOREAN WAR}

\section{Alleged US POWs}

According to an internal US Defense Department report published in June 1996 there was credible evidence that 10-15 American prisoners from the Korean War were still in North Korea. The official North Korean news agency denied the report as a false rumour.

Under an agreement of May 1996 the two countries were scheduled to begin joint recovery of American remains in July 1996.(IHT 01-07-96)

\section{Temporary ('tentative') peace accord}

Repeating a similar offer made in February, North Korea urged the US on 25 July 1996 to sign a temporary peace accord and in that case envisaged a breakthrough in the negotiations for a permanent one, the returning of remains of US servicemen and the curbing of North Korean missile exports.(IHT 26-07-96)

\section{LABOUR}

\section{Prohibition of child-labour}

Faced with threats of trade sanctions, the minister of labour of Pakistan ordered raids against factories that used child labour.(IHT 17-07-96)

\section{US and EU pressures on labour rights}

At the ASEAN meeting with its dialogue partners in July 1996 the US and the EU again raised the issue of global workers' rights, but the ASEAN warned the West not to raise divisive 'social clauses' in trade.(IHT 25-07-96)

The US and Europe complained that low wages and an absence of collective bargaining rights give developing countries an unfair trading advantage, while the developing countries consider efforts to promote labour standards a form of protectionism. The developed countries contend that competition from products made with cheap labour in Asia is costing them employment possibilities. But Japan opposed linking human rights and labour standards to trade: "Our position is that human rights [and] 
labour standards are very important issues in their own right, but they should not be used as a pretext for protectionism".(IHT 26 and 27/28-07-96)

\section{Abolition of child labour}

Facing US threats to cut imports, the garment industry in Bangladesh announced it had discharged all child workers. Under an agreement of July 1995 the Bangladesh Garment Manufacturers and Exporters Association, together with ILO and UNICEF, would take more than 10,500 former child workers to schools. Under the agreement child workers had to be phased out by 31 October 1996.(JT 02-11-96)

\section{LITIGATION}

\section{World Court accepts jurisdiction in Iran-US dispute}

The International Court of Justice decided on 12 December 1996 that it had jurisdiction in the case of the claim of Iran relating to the destruction by the US of oil platforms in 1987 and 1988, during the Iran-Iraq War.(IHT 13-12-96;ICJ Communique No.96/33)

\section{LOANS}

\section{World Bank loans in 1996 fiscal year}

According to the World Bank annual report the bank made new loan commitments during the year ending 30 June 1996 amounting to $\$ 5.42$ billion for the Asian region. Of the amount China borrowed $\$ 2.97$ billion or 55 percent, equaling 13.9 percent of the total commitments.

China topped the world list of borrowers, followed by India with $\$ 2.08$ billion. Vietnam ws the 10 th biggest borrower, at $\$ 502$ million.(JT 27-09-96)

\section{Pakistan accepts IMF conditions}

Pakistan bowed to IMF demands in October 1996 to impose new taxes, reduce its budget deficit and slash its tariffs. This was done in order to get the IMF to release the final payment of a $\$ 600$ million emergency standby loan negotiated in 1995 . The IMF had withheld the money because it said Pakistan had not lived up to its end of the bargain.(MainichiDN 12-10-96)

\section{Chinese loan for Pakistan}

In early 1997 the economic situation of Pakistan and its foreign exchange reserves were precarious. It had short term debt repayment obligations and had already borrowed 96 billion rupees from the domestic banking system. In December 1996 China granted a loan of $\$ 150$ million and in late May another $\$ 200$ million.(FEER 29-0597:12) 


\section{MACAO}

\section{Sino-Portuguese talks}

The two countries on 1 November 1996 finished their latest round of talks on Macao's transfer to Chinese rule in 1999 with two new accords, and progress toward a consensus on the gambling industry.

The two initialed accords concerned the maintenance of Macao's air transport agreements with Pakistan, Brunei and Korea and its membership in international postal and telecommunications unions.

Negotiations continued on questions of nationality and passports, civil servant pensions, state concession contracts and a Portuguese-language school beyond 1999.(JT 03-11-96)

\section{MERCENARIES}

\section{Use of mercenaries in Papua New Guinea}

It was reported that PNG had used mercenaries in its fight against insurgents on the island of Bougainville. The mercenaries were hired by the government from 'Sandline International', a British-based supplier which sub-contracted to 'Executive Outcome', a private South African army.(IHT 03-03-97)

The mercenary contract outraged the military, and on 17 March 1997 the commander of the army moved against the government, demanding that the prime minister resign. The latter dismissed the general. Meanwhile the mercenaries left the country on 21 March.(IHT 22/23-03,04-04-97;FEER 27-03-97:13)

\section{MIGRANT WORKERS}

\section{The Malaysian situation}

It was reported that out of a work force of 8 million, there were 1.75 million foreign workers in Malaysia, of whom only 750,000 were legally employed. In the 1980 s Indonesians were the main unskilled migrants. In the 1990s, however, unskilled workers had come from various countries, with most illegals coming from Indonesia and Bangladesh.(FEER 31-10-96:17)

\section{MILITARY ALLIANCES}

\section{South Korean-US military exercises}

By way of response to the incursion by a North Korean submarine (see supra p.415) the South Korean defence ministry said it would seek to restart joint military exercises with the US. The exercises had been held annually since 1976 but were suspended in 1994 as part of the arrangements concerning the alleged North Korean nuclear programs.(IHT 25-09-96) 


\section{US bases on Okinawa}

(see 6 AsYIL 421,425)

Okinawa accounts for 0.6 percent of Japan's total land area but provided about 75 percent of the land taken up by US military facilities in Japan. About 28,000 of the 47,000 US troops stationed in Japan are in Okinawa.(JT 10-10,24-10-96)

In April 1996 Japan and the US agreed on the total or partial return of 11 military bases at Okinawa, or about 5,000 of the approximately 25,000 hectares now used by the US. On 31 October the agreement was partially implemented by the partial reversion of four bases.(JT 01-11-96)

Japan had also formally agreed to provide the US navy with a floating dock for maintenance work following the refusal of a Japanese private dry dock to have its dry dock used as it would jeopardize its business.(JT 09-11-96)

During his visit to Japan early December 1996 the US defense secretary and the Japanese government announced the final consolidation and relocation plans for the US military bases in Okinawa. It was agreed to build a sea-based (offshore) facility for relocating a key marine corps heliport from Futenma Air Station that was to be closed. It was widely believed that it would be built on an open sea area.(JT 30-11,0312-96) An agreement was concluded on reducing the US military presence on Okinawa, the return of about 12,000 of the 58,000 acres used by the US military, changes in training of marines and flight operations and reduction of aircraft noise.(IHT 01-1296)

The Japanese prime minister assured the US on 31 March 1997 that Japan would continue to provide land for the US bases on Okinawa (see 6 AsYIL 421,425) so as to fulfill its obligation under the Japan-US Security Treaty. For that purpose the land expropriation laws would be revised, giving the government a temporary extension of its leases on land occupied by the bases after the current contracts expired on 14 May 1997. Under the current legislation the case of landowners who refused to renew their contracts was dealt with by an Okinawa land expropriation committee which would not render its decision before that date.(IHT 01-04-97)

\section{US - Japan}

(see also: Inter-state relations (China-Japan-US)

Japan and the US had been contemplating ways of improving their responses to crises under an agreement reached at a summit meeting in April 1996 (see 6 AsYIL 426). Repeating its objections, China through its embassy in Washington on 8 October 1996 again voiced concern about a proposed expansion of the scope of Japan-US security co-operation outside Japanese territory. Such expansion would make the Asian security situation complicated.(JT 10-10-96)

The US defense secretary visited Japan in early April 1997. The purpose of his visit was to "discuss regional security issues and the role that Japan and the US will play". More specifically, he came to seek assurance of non-combat support from Japanese forces in a Korean conflict and to urge Japan to join a US missile-defence initiative (see: Military co-operation). In the same month the Japanese prime minister visited the US and assured that Japan was not seeking a cut in US military forces in Asia. 
The two countries were negotiating an update of their 1978 joint 'defence guidelines' for security co-operation. The US wanted firm assurances for the use of Japanese bases for operations and transportation in case of a new war in Korea.(ST 08-0497;IHT 01 and 08-04,27-05-97)

Tentative new guidelines were released on 7 June 1997, contained in an interim report of six months of talks to review the 1960 US-Japan Security Treaty. The revision of the existing guidelines resulted from the near-crisis in 1994 over the alleged North Korean nuclear weapons program, when gaps in the US-Japan understanding over their co-operation on crisis-management became obvious. The need for revision was enhanced by the Sino-US tension over Taiwan in March 1996. The new guidelines, of which the consistency with the Japanese constitution was considered questionable by some, gave Japan an enhanced military role in the Asia-Pacific region in the event of "situations in areas surrounding Japan". (IHT 7/8-06,09-06-97;FEER 2606-97:18,40) A final version of the guidelines was released on 23 September 1997.

Even before the release of the tentative guidelines, the 'China Daily' wrote in early April 1997 that "since the US views China as a potential threat in Asia, it strengthened its military ties with Japan and embarked on a policy of containing China".(IHT 10-04-97)

According to Japan's Kyodo news agency the guidelines "appear to allow the US to get Japan's assistance when the former dispatches troops in an emergency on the Korean Peninsula, the Taiwan Straits, the disputed Spratly Islands in the South China Sea or anywhere else in areas surrounding Japan". Among other things, the Japanese military should conduct minesweeping in international waters and supply air and naval facilities, materials and fuel, although not weapons and ammunition, to US forces in the event of an Asian conflict. The new guidelines were deliberately vague in defining what 'situations' could give rise to such co-operation. Japanese officials said they could not define the specific geographical area where the regional contingencies envisaged in the guidelines could take place.(IHT 10-06,11-06-97;FEER 19-06-97:13,26-06-97:18)

\section{MILITARY CO-OPERATION}

\section{Singapore-UK military ties}

A visit to Singapore by the British Defence Secretary was hailed in a statement by the Singapore Ministry of Defence as a reflection of the close bilateral defence ties between the two countries and the UK's commitment to the Five-Power Defence Arrangement (FPDA, between Singapore, Malaysia, Australia, New Zealand and the UK). The statement added that Singapore valued its close and historical ties with Britain.(ST 13-09-96)

\section{South Korean-US military exercises}

By way of response to the incursion by a North Korean submarine (see supra p.415) the South Korean defence ministry said it would seek to restart joint military exercises with the US. The exercises had been held annually since 1976 but were sus- 
pended in 1994 as part of the arrangements concerning the alleged North Korean nuclear programs.(IHT 25-09-96)

\section{British navy visit to China}

The first British navy ship to visit China in 10 years docked in Qingdao on 7 October 1996.(AsahiEN 08-10-96)

\section{Singapore-Australian naval exercises}

The two navies held their annual exercise off northern Australia.(IHT 12/13-1096)

\section{China - US Joint Defense Conversion Commission}

It was reported that the US defense secretary decided to abolish the Joint Defense Conversion Commission (see 5AsYIL 464), because he considered it to have achieved little. When the Commission was set up in October 1994, the two sides agreed "to promote the orderly use, for peaceful purposes, of defence industrial, technological and scientific facilities and personnel not needed for defence requirements". Later, in the context of deteriorating Sino-US relations resulting from the US visit of the Taiwanese president, US sympathy with the project swiftly diminished. Among other things the continued flow of technology from the US to China raised concerns in America that export controls on such know-how were too lax.(FEER 15-08-96:13, 2208-96:26) However, it was reported in November 1996 that the US General Accounting Office had found no evidence that the Commission activities had resulted in the transfer of technology or funds to the Chinese Army.(FEER 21-11-96:15)

\section{Sino-US naval agreements}

The Chinese defence minister said during his US visit in December 1996 that China had tentatively approved continued US naval visits to Hongkong after the colony would be turned over to China in 1997.(IHT 11-12-96;JT 11-12-96)

The two parties also agreed to hold periodic high-level defence consultations and exchanges of ship visits. In addition the US proposed a 'rules of the road' agreement for naval operations modeled on a similar US-Soviet agreement of 1989 for the purpose of avoiding military conflicts when ships come too close to one another or their intentions are suspect. It was agreed that the draft would be formalized in a series of working groups.(IHT 11-12-96;FEER 26-12-96/02-01-97:13)

In March 1997 Chinese navy ships made their first port visit to the US, sailing into San Diego Bay.(IHT 24-03-97)

\section{France - China}

During the first visit to China ever since the establishment of diplomatic relations in 1964, the French defence minister on 7 April 1997 urged China to increase SinoFrench co-operation in all military fields. He said that France wanted to engage in a strategic dialogue with China to develop exchanges between the armed forces and study possible co-operation in technical matters.(ST 08-04-97) 


\section{Myanmar - China}

China and Myanmar concluded an agreement to strengthen military co-operation, consisting of, inter alia, training of members of the Myanmar armed forces and 'fiscal assistance'.(FEER 30-01-97:12)

\section{US-Japanese anti-missile defence project}

It was reported that exploratory talks on the issue which had been held during the past three years might end in a negative way with Japan deciding not to join the project. It was said that the US would press ahead with the project to protect US forces based in Japan from a possible North Korean or Chinese attack. The US-Japanese discussions began shortly after North Korea test-fired a Rodong-I missile into the Sea of Japan in 1993.

The Chinese argued that a Japanese anti-missile program would undermine regional arms control efforts and China's nuclear deterrent, particularly against US military bases in the region.(IHT 15/16-02-97)

\section{US-Vietnam links}

The commander of the US Asia-Pacific forces on 21 March 1997 called for stronger links with Vietnam, to help "promote greater Pacific Rim security".(IHT 22/23-03-97)

\section{Five Powers Defence Arrangement (FPDA)}

The FPDA, consisting of Australia, Malaysia, New Zealand, Singapore and the UK held naval exercises in late April 1997. The FPDA was formed in 1971 to protect Singapore and Malaysia from communist invasion. Nowadays and in the future, it will be more a focal point for military training rather than a strategic body. For the nonAsian members, it provides benefits: through it Britain as well as Australia can project power in Southeast Asia without drawing regional criticism.(FEER 15-05-97:26)

\section{Renewed US use of Philippine port}

Five years after its abandonment of the Subic Bay naval base, the US started negotiations with the Philippines to use the port and its facilities more frequently in order to maintain a stronger naval presence in the South China Sea.(IHT 21-05-97)

\section{Indonesian withdrawal from US training program}

It was reported that Indonesia had withdrawn from a US-sponsored military education and training program from which it was barred in 1992 after the killing of demonstrators in East Timor and to which it was re-instated in late 1995 (see 5 AsYIL 467; infra p. 476).(IHT 7/8-06-97)

\section{Russian navy visit to Japan}

A Russian navy vessel arrived in Tokyo harbour on 27 June 1997 for a goodwill visit, the first to Japan by a Russian warship in 103 years.(IHT 28/29-06-97) 


\section{MINORITIES}

\section{Koreans in Japan}

At the end of World War II there were about 2.5 million ethnic Koreans in Japan. After repatriation of most, 600,000 remained in 1948. Most of these originated from the southern half of Korea. In October 1945 the League of Koreans in Japan, closely linked to the Japanese Communist Party, was founded, while other, anti-communist, organizations which were also established, merged to become the Korean Residents Union in Japan (Mindan) in 1946. The division was originally not related to the subsequent division of the country. The League was reorganized and became the General Association of Korean Residents in Japan (Chongryun) in 1955, severing its ties with the Japanese Communist Party.

At present most of the 670,000 Koreans in Japan and their descendants have been granted permanent residence status, while 190,000 have acquired Japanese nationality since 1952. The annual number of naturalized Koreans reached 10,000 in 1995. According to estimates by the Japanese authorities, 369,000 of the permanent residents are affiliated with Mindan while 247,000 are affiliated with Chongryun, with 63,000 being neutral. The Japanese authorities had not publicized statistical breakdowns since 1971 to avoid feeding conflict between the organizations.

Each organization considers all Koreans their compatriots. Affiliation with either ethnic organization appears not to reflect the nationality of the person concerned. North Korean nationality is not recognized by the Japanese government because Japan has not recognized the DPRK.

The Japanese aliens registration provides for two asymmetrical categories: 'South Korea' for those who identify themselves as South Korean nationals, and 'Korea' for those who do not do so, including those being 'neutral'. It is said that as of 1992, 540,000 were registered as South Koreans and 150,000 as 'Koreans'.(JT 19-11-96)

\section{Ethnic Nepalis from Bhutan}

As a result of several reasons (see 2 AsYIL 349, 3 AsYIL 423) more than 100,000 ethnic Nepalis from Bhutan were reported living in refugee camps in southern Nepal, with uncertain nationality. According to the Bhutanese foreign minister many of these persons had never been Bhutanese citizens, but just illegal immigrants who had been living in southern Bhutan. This would be part of the generally acknowledged fact of Nepalese emigration to neighbouring countries. Such Nepalese newcomers were to be distinguished from a long-existing ethnic Nepalese minority settled in the Bhutanese lowland. An enormous increase of ethnic Nepalese in the country was shown by a 1988 census and led to a Bhutanese nationalist policy, Driglam Namzha, including the promotiion of the national language (Dzongkha) and an obligation for citizens to wear the traditional Bhutanese dress. This in turn resulted in conflicts between the Bhutanese government and the ethnic Nepali, leading to an exodus of the latter to Nepal.

It was agreed that Nepal was entitled to send back those among the refugees who had Bhutanese nationality. The two sides had agreed to jointly verify the citizenship of the refugees, with technical assistance from the UN High Commissioner for Refugees. However, Bhutan insisted that the nationality laws of both countries be the basis for 
the verification. This was rejected by Nepal because under Bhutanese law citizenship is lost automatically by emigration.(FEER 25-07-96:30)

[Among the population of Bhutan the Drukpa (Tibetan descendants) form approximately $20 \%$ and occupy the northern part of the country. They speak Dzongkha and practise Himalayan Lamaist Buddhism. Sharchhops of Indo-Burmese origin live in the eastern region and constitute around $30 \%$ and practise the same religion. The Lhotshampa are Nepali-speaking Hindus of Indo-Aryan origin, began immigrating from Nepal since the late $1800 \mathrm{~s}$, make up about half of the population, and tend to dominate the south. The king belongs to the Drukpa part of the population.

In 1958 the first Citizenship Act was introduced: Ethnic Nepalese who had been in the country for at least 10 years and owned agricultural land became Bhutanese citizens. Under a new Citizenship Act of 1985 "[A] person permanently domiciled in Bhutan on or before 31 December 1958, and whose name is registered in the census registration ... shall be deemed a citizen by registration". Many of the southern Lhotshampas were declared non-nationals and illegal immigrants by lack of formal proof of fulfilling the requirements.]

\section{MISSILE TECHNOLOGY}

\section{North Korean missile tests and proliferation}

US reconnaissance satellite images had led to reports about North Korean preparations for a missile test-launch in the Sea of Japan, but these conclusions were later denied by the US itself. Yet the US sent "a very strong message" to North Korea not to carry out a medium-range ballistic missile test. The latest test-launch of a mediumrange missile by North Korea took place in May 1993.(JT 17-10,18-10,20-10-96)

Later North Korea agreed to meet the US on 12-13 May 1997 in New York for talks about missile proliferation.(IHT 15-04-97)

\section{Development of long-range missiles by South Korea}

South Korea and the US were to hold talks on allowing South Korea to develop long-range missiles. Under a US-South Korean agreement of 1979 the latter had promised not to develop missiles with a range of more than $180 \mathrm{~km}$, but it wanted this ceiling to be lifted to $300 \mathrm{~km}$ in order to counter threats from North Korea. $300 \mathrm{~km}$ is the maximum range allowed under the (currently 31-state) Missile Technology Control Regime (see 1 AsYIL 270) to which South Korea was not yet a member. Meanwhile South Korea denied that it was already developing a long-range missile.(FEER 12-09-96:36;JT 30-11,04-12,05-12-96)

\section{India shelves missile production}

In August 1996 the Indian foreign minister divulged in an interview that India was likely to resume long-range missile testing after a halt of more than two years, despite US pressure for a permanent cessation. It would start its own program to make cryogenic rocket engines. In 1993 the US had blocked a move by Russia to transfer their technology to India (see 4 AsYIL 484). There had been no further test firing of the 
long-range 'Agni' missile since February 1994. The Agni has a range of 2,500 kilometres.

In December 1996, however, India shelved the development of the 'Agni', although it would keep its options open to resume the program.(JT 07-12-96;IHT 2108,30-12-96)

In February 1997 it was announced that India would test the Prithvi missile on 24 February.(IHT 22/23-02-97)

\section{MONETARY MATTERS}

\section{Asian central banks co-operation}

It was reported that 11 Asian-Pacific central banks from Australia, Japan, Indonesia, South Korea, Malaysia, New Zealand, the Philippines, Singapore, Thailand, China and Hongkong - members of the Executives Meeting of East Asian and Pacific Central Banks - had decided to set up permanent working groups to discuss ways of enhancing co-operation. The banks were already negotiating repurchase agreements, giving them access to the financial resources needed to defend local currencies during a flight of capital.

The governor of the Reserve Bank of Australia who had pursued the closer cooperation, questioned the ability of multilateral monetary authorities to react to regional crises, such as major attacks on a local currency, as they were not keeping up with such market developments. He envisaged Asian central banks moving towards setting up the equivalent of the Bank of International Settlements.(IHT 09-08-96)

Financial and central-bank officials from six Asia-Pacific countries ('Six Markets Group') met for the first time in early March 1997 and agreed to work closely together to avert Mexico-style (1994) currency crises in the region. The six countries were: Japan, US, China, Hongkong, Singapore, and Australia, and accounted for 48 percent of the world's economic activity, a third of its foreign exchange reserves and 31 percent of its trade.

Since 1992 Japan, Australia, Hongkong and Singapore had been meeting regularly to discuss financial issues. After the Mexican peso crisis they agreed to co-operate on intervention to stabilize regional currencies, and invited the US and China to join the meetings. The Bank of Japan had forged agreements in 1996 establishing it as a lender of last resort for seven other Asian central banks in stemming any attacks against their currencies.(IHT 05-03-97)

\section{Expansion of membership of the Bank for International Settlements}

The BIS announced on 9 September 1996 that it would expand its membership from 32 (33 since the dismemberment of Czechoslovakia) to 41 (42) by March 1997, by including, inter alia, Brazil, China, Hongkong, India, Mexico, Russia, Saudi Arabia, Singapore, and South Korea. The BIS was originally set up in 1930 to process German reparations payments from World War I, but evolved into an informal coordinating centre for central banks. It helps to process international payments, to manage currency reserves and to offer a monthly meeting place for top monetary officials. It is dominated by the so-called Group of $10(\mathrm{G}-10)$ that actually has 11 members: 
Belgium, Canada, France, Germany, Italy, Japan, The Netherlands, Sweden, Switzerland, UK, US. The other members of the BIS are: Australia, Austria, Bulgaria, the Czech Republic, Denmark, Estonia, Finland, Greece, Hungary, Iceland, Ireland, Latvia, Lithuania, Norway, Poland, Portugal, Romania, Slovakia, South Africa, Spain, Turkey and Yugoslavia.(IHT 10-09-96)

\section{Chinese yuan convertible under the current account}

China decided to make the yuan convertible under the current account as of 1 December 1996 in conformity with its obligations to the IMF.

[Convertibility under the current account is trade-related and covers payment for goods and services as well as repatriation of profits by foreign companies from operations in China](JT 29-11-96)

\section{Speculation on the Thai baht}

According to the Thai central bank on 24 June 1997 the foreign financier GEORGE SOROS had led an attack on the Thai baht in May 1997 that drove the currency to an 11-year low. Traders betting the baht would fall, borrowed the currency [to buy foreign currency] with the intention to buy it later [in order to pay back] at a cheaper rate. This prompted Thailand to impose currency controls and raise interest rates.(IHT 25-06-97) It was said that Thailand spent about $\$ 5$ billion in May 1997 to shore up its currency and it was not clear how long Thailand could fend off a devaluation.(IHT 2606-97)

\section{NATIONALITY}

See: Hongkong, Inter-state relations (China-South Korea), Minorities

\section{NON-ALIGNED MOVEMENT (NAM)}

\section{New Delhi ministerial conference}

The NAM, under chairmanship of Colombia, held a ministerial conference in New Delhi on 7 and 8 April 1997. It was attended by 74 ministers (from a membership of 113). The conference dealt with UN reforms and an enhanced role of the NAM, nuclear disarmament, and economic development of the Third World.

On UN reforms the declaration adopted by the conference said, inter alia: "The use of the veto should be curtailed with a view to its eventual elimination. There shall be no partial or selective expansion or enlargement of the Security Council to the detriment of the developing countries."

The conference also elected South Africa as chairman of the movement [for the term 1998-2001, starting at the 12th Summit at Durban, August-September 1998].(ST 08-04,09-04-97;IHT 07-04-97) 


\section{NUCLEAR ENERGY MATTERS}

\section{Implementation of KEDO agreement}

It was reported that the implementation of the 1994 agreements relating to the replacement of existing North Korean nuclear installations with safer ones met with problems (see 5 AsYIL 545).

Among the participants it was agreed that the US would pay $\$ 50$ million, or about half of the amount needed, for the supply to North Korea of 500,000 tons of heavy oil annually during the time the new reactors are under construction.

Since 1994 the US had financed \$26.5 million. In early July 1996 the US Congress initially cut further funding from $\$ 25$ million to $\$ 13$ million. North Korea denounced the decision and threatened that if the oil was not supplied on time, it would reconsider its nuclear freeze. The full amount was eventually appropriated, but a $\$ 19$ million Japanese emergency contribution was needed to keep the oil supply running.(see 6 AsYIL 435).

In 1997 the US on behalf of KEDO asked a contribution of $\$ 15$ million from the Arab Gulf states but was rebuffed.

The participants also agreed that the cost of the new reactors, about $\$ 4$ billion, would be borne by Japan and South Korea, since the US was already spending $\$ 2.5$ billion annually for its forces in Korea.(IHT 03-07,22-07-96,26-02-97;FEER 25-07-96 p.22)

\section{The projected building of KEDO nuclear reactors}

In July 1996 the executive director of KEDO announced that the project of building two nuclear plants in North Korea was proceeding smoothly and that the building could begin during the year. The price of the project would be $\$ 4.9$ billion.(IHT 25 and 27/28-07-96) Within KEDO it was agreed that the Korean Electric Power Corporation of South Korea would be the prime contractor for the reactor project.(IHT 2603-97) However, the Organization decided to freeze the building of the reactors in North Korea due to the North Korean submarine incident in September 1996 (see above p.415). On the other hand North Korea threatened to lift the freeze on its nuclear program if KEDO failed to start construction work at the scheduled time, i.e. by the end of 1996.(JT 23-10-96) On 15 November 1996 North Korea warned again it could not keep its nuclear program frozen "only to get heavy oil, the shipments of which may be suspended any time, with no importance given to when the light-water reactors will be provided".(IHT 16/17-11-96)

By March 1997 KEDO already had ten members with additional states making financial contributions. It was reported that the EU would also become a member and member of the executive board (see KEDO constitution in 5 AsYIL 547).(IHT 26-0397)

\section{Planned Chinese sale of nuclear facility to Iran}

China notified the IAEA in 1996 that it planned to go ahead with the sale of a nuclear plant to Iran which needed the facility to make fuel rods for its civilian nuclear program. Being a party to the Nuclear Non-proliferation Treaty the plant would be open to international inspections. 
The US, however, suspected Iran to use the treaty as a cover to develop nuclear weapons, and tried to prevent the Chinese sale. In fact, Russia provided more assistance in the nuclear field to Iran than China.(IHT 09/10-11-96; JT 10-11-96)

\section{Developments in Sino-US nuclear co-operation} (see also: Embargo)

In 1985 the two countries concluded an agreement on co-operation in the field of peaceful use of nuclear energy. This agreement would enable China to procure nuclear reactors from the US for the implementation of its energy planning. The agreement had not yet been put into effect since under US law the US president has to certify that China is not assisting unsafeguarded nuclear facilities or, in other words, that it is not engaging in nuclear proliferation.

In the late 1980s when certification was under way, the US claimed evidence of Chinese sales and other assistance to Pakistan, and since the Tienanmen incident in 1989 the whole process was frozen.

In the meantime China had become a party to several treaties on the matter, such as the Non-proliferation Treaty, the Comprehensive Test Ban Treaty and the Chemical Weapons Convention. On 11 May 1996 China agreed not to provide aid in the form of devices used in nuclear arms production to unsafeguarded nuclear facilities, and said it would join the so-called Zangger Committee, which draws up a list of items that should be subject to IAEA inspections if exported by a signatory of the NPT. This set the stage for new talks with the US. (JT 01-11-96;FEER 19-06-97:14)

The talks started in November 1996 when the US secretary of state said that the US "is prepared to consider, as consistent with US law, further steps in the area of peaceful nuclear co-operation even in advance of our full implementation of the 1985 agreement". It was later said that certification would require three steps: a further curtailment of China's nuclear co-operation with Iran, full membership in the Zangger Committee, and the adoption of nationwide regulations to control exports of sensitive items. That is, provided the US Congress did not pass a law making the standard for certification even stricter, such as requiring the non-export of other than nuclear technology, such as chemical and biological weapons, and the non-diversion of US-made civilian supercomputers to military use.(AsahiEN 21-11-96;JT 22-11-96;FEER 19-0697:15)

It was reported that China had agreed to establish a system for tracking the exports of nuclear materials, constituting a step toward the implementation of the 1985 agreement.(IHT 21-11-96)

\section{Regional co-operation in the field of nuclear safety}

Australia, China, Indonesia, Japan, Malaysia, the Philippines, South Korea, Thailand and Vietnam held a conference in Tokyo in early November 1996 to discuss ways to ensure the safety of nuclear power plants and increase the transparency of nuclear power generation in the region. Participating as observers were the G-7 states apart from Japan, India, Pakistan, Russia, Singapore,Uzbekistan, the EU, the IAEA and the NEA of the OECD. The conference was an Asian follow-up to a nuclear safety summit held in April 1996 by the G-7 and Russia.(JT 06-11-96) 


\section{Resumption of IAEA-North Korean talks}

After having failed to reach agreement in September 1996, the two parties would resume talks in January 1997 on the monitoring of the freezing of North Korea's nuclear program, particularly the aspect of provision of data on the trafficking of nuclear material.(JT 05-12-96)

\section{Second Chinese nuclear reactor for Pakistan}

(see also: Inter-state relations (China-Pakistan))

According to the Pakistani foreign ministry, China was willing in principle to provide a second nuclear power plant to Pakistan, next to the one at Chasma in Pun$\mathrm{jab}$, under the safeguards of the IAEA. The question of financing was not yet resolved.(IHT 06-12-96;AsahiEN 06-12-96)

\section{Second shipment of nuclear waste for Japan}

The French state-owned nuclear power company COGEMA sent a second shipment of radioactive reprocessed nuclear waste to Japan (see AsYIL Vol.2:357, Vol.3:428, Vol.5:476) in early 1997.(AsahiEN 06-12-96) The British ship 'Pacific Teal' left Cherbourg, France, on 13 January 1997 and charted a course around the Cape of Good Hope, across the Indian Ocean and through the southwest Pacific. The ship would arrive at the Japanese port of Mutsu Ogawara in mid-March 1997. New Zealand expressed strong concern about the planned route, and Malaysia banned the ship from its waters.(IHT 15,16-01-97)

\section{Taiwan-North Korean nuclear waste pact}

Under a contract of 11 January 1997, the state-owned Taiwan Power Co. (Taipower) would ship 200,000 barrels of low-level nuclear waste over two years to North Korea. It was reported that Taipower had agreed to pay $\$ 1,150$ per barrel taken by North Korea. The Taiwanese foreign ministry said it was satisfied that North Korea was capable of handling low-level radioactive nuclear waste and that the contract complied with international regulations. South Korea strongly objected to the arrangement, saying that there was no verification that North Korea could store the nuclear waste safely. The disposal site was less than 65 kilometres from the NorthSouth border.(IHT 28-01,8/9-02-97;FEER 06-02-97:16)

\section{India - Russia}

The two countries failed to reach agreement on the sale by Russia of two nuclear reactors on 25 March during a visit by the Indian prime minister to Moscow in March 1997. Talks on the $\$ 2$ billion sale of two reactors to be built in the state of Tamil Nadu began in 1988.(IHT 26-03-97)

\section{Iran - Ukraine}

Ukraine responded to US and Israeli pressures by deciding not to supply turbines for a nuclear reactor that Russia was to build for Iran (see 6 AsYIL 436).(IHT 16-0497) 


\section{OIL AND GAS}

See also: Divided states:China, Foreign investment, Joint development

\section{Natural gas consumption, production, reserves}

It was reported that three quarters of the world's liquid natural gas (LNG) was being sold to Japan, South Korea and Taiwan, with new consumers like China, India and Thailand entering the market. Asian demand would more than double to as much as 138 million tons a year by 2010 , compared to about 55 million tons in 1995 . The fuel comes mainly from Abu Dhabi, Alaska, Australia, Brunei, Indonesia, and Malaysia, with Indonesia being the largest exporter. The Middle East accounts for a third of the world's proven gas reserves but only 6 percent of world production.(IHT 06-0896)

Atlantic Richfield Co.(Arco) of the US, under production sharing contracts with Pertamina (the Indonesian state-owned oil company), had found new natural gas reserves at Irian Jaya province ('Wiriagar Deep'), and British Gas had found significant gas flows in its concession, adjacent to the Wiriagar Deep fields. These reserves were believed to be less large than the Natuna gas deposit ('D-Alpha'), at present considered the world's largest, but the Irian Jaya fields were said to be much easier and cheaper to tap than Natuna.(FEER 12-09-96:54-55,24-10-96:70;JT 19-11-96)

\section{Philippine gas field}

Occidental Philippines and Shell Philippines Exploration would reportedly join National Power Corp. of the Philippines in tapping the Camago-Malampaya gas field, the country's largest, and build a pipeline to the island of Luzon.(FEER 05-12-96:75)

\section{Oil, gas, and pipelines politics in Central Asia}

The Karakorum desert holds the third-largest gas reserves in the world and has estimated oil reserves of 6 billion barrels. Attempts by Turkmenistan to build the necessary pipelines to convey the oil and gas through the territory of its neighbours had, however, been blocked by various reasons, and for years the former Soviet pipeline system had been the only means to export oil and gas from Central Asia westwards.

Lately the US had been vying for influence in Uzbekistan by making investments and enhancing trade, as a counterweight to Russian hegemonism and Iranian influence. Uzbekistan plays an important role in the whole Central Asian region, with large Uzbek minorities in the surrounding Central Asian states. It was reported that there were thus two major coalitions emerging: the US lining up with Uzbekistan and Turkmenistan on the one hand, and Russia together with Kazakhstan, Kyrgizstan, Tajikistan and Iran on the other.

Feasibility studies were being made for a new network of pipelines from Turkmenistan, such as a project involving Mitsubishi of Japan, China National Petroleum Corp. and an affiliate of Exxon of the US, concerning an 8,000-kilometre gas pipeline stretching from Turkmenistan to Japan. Another project is concerned with a pipeline heading south through Afghanistan to Pakistan. This project is the subject of fierce competition between Unocal of the US and Bridas of Argentina. Still another scheme 
is a pipeline from Central Asia towards Iran, which offers the shortest route to the Arabian Sea.

In April 1995 Turkmenistan concluded a deal with Iran and Turkey for a pipeline, with Iran offering to pay for the first part linking the gas fields in western Turkmenistan with northern Iran. Under a 29 December 1996 agreement Turkey committed to purchase an annual $8 \mathrm{bcm}$ of gas via the new pipeline. Iran would provide Turkey the gas in a swap deal until the rest of the pipeline would be laid. Turkmenistan too had signed an oil-swap deal with Iran to export oil to Europe.(see for similar schemes: supra p.451)

The US is supporting the Turkmenistan-Afghanistan-Pakistan pipeline project, which would offer an exit point to Central Asian oil and gas while bypassing Russia and Iran.(FEER 10-04-97:22) The project might forge peace in Afghanistan and prevent future energy shortages in Pakistan.

The idea of a pipeline from Turkmenistan south through Afghanistan to Pakistan, originated in the award, in early 1992, to Bridas oil company of Argentina, of the Yashlar oil and gas block in the Dauletabad fields of eastern Turkmenistan, and of the Keimar oil block a year later. The plan includes a 1,300-kilometre gas pipeline from Yashlar, crossing western and southern Afghanistan to Sui in central Pakistan. The line could be extended to India as well as Karachi for gas exports to East Asia. Bridas signed an agreement with the Afghan government of president RABBANI in February 1996, and also with the Taleban (supra). It had set up TAP Pipelines, a partnership with the Saudi company Ningharco which is being linked to members of the Saudi power elite.

In April 1995, however, Turkmen officials met Unocal, and reportedly with the backing of the US government the Turkmen president signed an agreement with Unocal and its Saudi partner, Delta Oil, to build a(nother) gas pipeline. Unocal's proposal is for a pipeline extending from the Dauletabad gas fields through Afghanistan to Multan in eastern central Pakistan. It set up a consortium which included itself, Delta Oil, Gazprom of Russia, and Turkmenrosgaz, and which had to be announced by 1 October 1997. Unocal was committed to present a final report on the project by 30 June 1997, and to start construction by 31 December 1997 . There was, however, no certainty whether the Taleban would give permission to build the pipeline across their country.

Unocal also signed another agreement relating to the Central Asian Oil Pipeline Project including a pipeline from Chardzhou in northeast Turkmenistan to an oil terminal on Pakistan's coast west of Karachi.

In the same year, Turkmenistan moved against Bridas, banning its oil exports, shutting down its other operations, and demanding renegotiation of all Bridas contracts. In response, Bridas filed a suit against Unical in the US, seeking damages for alleged interference with its gas fields and pipeline project. Unocal's main defence against Bridas was that in May 1996 Uzbekistan, Pakistan, Turkmenistan and Afghanistan had signed an agreement allowing Turkmenistan to nominate Unocal's consortium to build the pipelines.

Bridas also began arbitration proceedings with the International Chamber of Commerce against Turkmenistan for breach of contract in three separate cases. On 28 January 1997 the ICC issued an interim order under which Turkmenistan was to allow 
Bridas to resume oil exports from Keimar. There were no signs that Turkmenistan would comply.(FEER 10-04-97:22-28,19-06-97:73)

\section{ORGANIZATION FOR ECONOMIC CO-OPERATION AND DEVELOPMENT}

\section{South Korea invited for membership}

The OECD on 11 October 1996 decided to offer membership to South Korea. An agreement on its entry as member would be signed on 25 October 1996.(JT 13-10-96) The South Korean parliament approved the membership on 26 November 1996.(JT 27-11-96) Korea finally became member on 12 December 1996.(JT 14-12-96)

\section{RAIL TRAFFIC AND TRANSPORT}

\section{Trans-Asian railways}

It was reported that plans put forward in the 1960s concerning a trans-Asian railway between the region and Europe were being revived. In Southeast Asia gaps exist between Thailand and Vietnam and between Vietnam and Cambodia. In ASEAN Malaysia was appointed in 1996 to co-ordinate a regionwide rail study.(IHT 31-07-96)

The 'Silk Road' rail cargo link between China and Europe through Central Asia (the third one next to those through the Russian Far East and through Mongolia) was reported to be finally in operation in early August 1996.(IHT 06-08-96)

\section{Iran-Turkmenistan rail link}

A rail link between the two countries was completed and opened on a limited basis in May 1996. The railroad originates in Mashhad, 450 miles east of Tehran, and runs east for 105 miles to Sarakhs. After crossing the Bridge of Friendship into Turkmenistan, it turns north to Tedzhen, where it links to the network serving Central Asia, Russia and the Caucasus. The new line represents an opportunity for the Central Asian republics to reduce their economic dependence on Russia by gaining access to new international markets through Iranian ports on the Persian Gulf.(IHT 11-12-96)

\section{RECOGNITION}

See: Civil war

\section{REFUGEES}

See also: Borders

\section{Admission of Vietnamese refugees for settlement in the Philippines}

The Philippines gave a reprieve to 1,000 Vietnamese asylum seekers, allowing them to stay in the country.(IHT 18-07-96) 


\section{Repatriation of Vietnamese refugees}

The last 486 of more than 10,000 Vietnamese asylum seekers in Indonesia were repatriated from Galang Island to Vietnam on 2 September 1996.(FEER 19-09-96:13)

\section{Repatriation of refugees from Bangladesh to Pakistan}

The Pakistan government declared its willingness to take back thousands of Urduspeaking refugees stranded in Bangladesh for more than two decades, since the establishment of the state of Bangladesh in the former territory of East Pakistan.

There were about 238,000 Urdu-speaking persons who sided with Pakistan during the war in 1971 and later opted for Pakistan as their homeland. Nearly 127,000 of the refugees, known as Biharis, were already resettled in Pakistan in the early 1970s.(IHT 19-08-96)

\section{North Korean refugees}

In view of the worsening economic situation in North Korea the question arose about the reason of the relatively small number of North Korean refugees, particularly to China. It was said that up to late 1996 some 1,000 persons had fled to China since 1992. One of the reasons listed was a 1986 treaty on the handover of illegal immigrants, under which those apprehended in China were instantly turned over.(FEER 10-10-96:27)

In May 1997 South Korean navy officials rescued a group of 14 persons who had fled North Korea by boat, the first to do so. They were the largest group of defectors since the arrival in December 1996 of a group of 17 who trekked through China and Hongkong.(FEER 22-05-97:13)

\section{Eviction of Chinese refugees}

It was reported that Indonesia had ordered a vessel with 200 Chinese refugees to leave when it came ashore on an island in West Nusa Tenggara Province (south eastern Indonesia). The refugees were heading to New Zealand.(IHT 24-02-97)

\section{Myanmar Karen refugees in Thailand} (see also: Borders)

A Myanmar army offensive aimed at wiping out Karen National Union rebels in February 1997 resulted in nearly 15,000 refugees entering Thailand. It was reported that in order to prevent Karen rebels among them from operating from its territory, Thailand had forced about 5,000, mainly male, Karen, back into Myanmar in late February 1997. It would thereby reverse a decades-old policy of sheltering refugees from Myanmar. The commander of the Thai forces in the area concerned, however, denied the forcible repatriation of refugees. Both countries stood to gain economically from an end to the Karen insurgency (see Foreign investment).(IHT 28-02,01/02-0397) 


\section{Asean Regional Forum}

The Asean Regional Forum met in July 1996 for the third time. Its membership was enlarged to 21 states and organizations by the inclusion of India and Myanmar. Except the annual ministers conference, civilian and military officials meet more frequently on confidence-building measures. It was reported that Western members had expressed reservations about Myanmar's entry, that India had agreed not to raise its disputes with Pakistan, and that the forum did not deal with the Taiwan dispute.(IHT 23-07-96;FEER 11-07-96:36)

\section{First multilateral discussion of regional security}

An (unofficial) Forum for Defence Authorities in the Asia-Pacific Region held its first meeting in late October 1996 since it was established in 1994 as a consultative body for security in the region. It was attended by all 21 members of the ASEAN Regional Forum except Brunei.

It was reported that the US maintained that the current military balance in the region owes much to the presence of the US armed forces, calling the US military the premise for regional security. The meeting also dealt with the importance of UN peace-keeping operations and humanitarian relief activities, anti-disaster measures, removal of anti-personnel land mines and prevention of international crimes.(JT 3110-96)

\section{Japanese-Canadian consultations}

At talks between the Japanese and Canadian prime ministers during the latter's stay in Japan on his way back to Canada from the Manila APEC meeting, it was agreed to launch bilateral consultations on security in the Asia-Pacific region.(JT 2811-96)

\section{Stationing of US forces in Asia}

During a trip to several Asian countries, the US defense secretary warned that any reduction of US troop numbers could trigger a dangerous arms race in Asia. In response the Chinese foreign ministry said that China opposed the stationing of foreign forces in the region: "We believe Asian nations should preserve the peace and stability of the Asian region. We believe Asian nations are fully capable of doing so." The spokesman recalled that the Chinese position had always been to oppose the stationing of foreign troops in Asia. During a meeting of the ASEAN Regional Forum in July 1996 (see supra) the Chinese foreign minister said that the presence of US forces in Asia was "a matter left over from history".(IHT 10-04-97)

In the first major defence review in four years by the US Defense Department the US defense secretary proposed maintaining 100,000 military personnel in Asia to preserve the balance of power.(FEER 29-05-97:13) 


\section{RIVERS}

Indo-Bangladesh sharing of water from the Ganges River (Hindi: Ganga, Bengali: Padma)

The two countries signed a new treaty on 11 December 1996 (text in 6 AsYIL 516) which has a 30-year validity period, replacing previous agreements of 1977 and 1982.

The level of water of the Ganges can vary dramatically between that during the monsoon and during the January-June dry period. The Ganges water is of crucial importance for millions of farmers in both countries, and the future of the port of Calcutta also depends on the quantity of water.

The Indian Farakka Barrage, built in 1974 near the border between the two countries, grew into a major source of friction. The dam curbed the flow of the river which irrigates much of northern India before flowing into Bangladesh. It also aimed at diverting Ganges water through the Hooghly River to Calcutta in order to prevent the port of Calcutta from silting up. Bangladesh charged that the dam held back too much water during the annual dry season and released too much during monsoon rains, causing flooding. The dispute caused Bangladesh to ignore Indian desires, such as a transit route to its northeastern state of Assam.

In 1977 an agreement was reached under which Bangladesh was allowed a guaranteed minimum of 1,020 cubic meters per second between October and June. That guarantee lapsed in 1982 and was not maintained in a new 1982 six-year agreement. Some years ago the Bangaladeshi prime minister raised the question in the UN General Assembly, but to no avail. An increasing number of Bangladeshi farmers left the country out of desperation and settled illegally across the border in India.

Under the new treaty, if the water flow at Farakka is below 2,100 cubic meters per second, as it usually is between March and May every year, the two parties will split the water equally. If the flow is between 2,100 and 2,250 cubic meters per second, Bangladesh will receive 1,050 cubic meters per second with the rest going to India. Above 2,250 cubic meters per second, India will be guaranteed 1,200 cubic meters per second and Bangladesh the rest. The treaty is to be reviewed every five years.

It was said that the treaty would last unless the overall flow of water at Farakka is reduced by upstream dams in India before the water reached the border region.(JT 14 and 20-12-96;NRC 12-12-96;IHT 13-12-96;FEER 26-12-96/02-01-97:16)

Unfortunately, in late March 1997, at a critical moment in the planting season, river levels dropped to such a low level that Bangladesh got only one sixth of the water pledged to it under the treaty. The treaty sets ten-day periods from March to May in which India and Bangladesh alternately take most of the water reaching Farakka, set at a minimum of 34,500 cubic feet a second. On 27 March 1997, during a period when the flows were supposed to favour Bangladesh, only 6,500 cubic feet was recorded, resulting in Bangladeshi officials accusing India of cheating and Indian officials angrily denying.(IHT 26-05-97) 


\section{Mekong River basin co-operation}

The litoral states of the Mekong river held a conference under the auspices of the ADB in early April 1997 for the promotion of co-operation in various fields in the Greater Mekong sub-region.(AsT 08-04-97)

\section{SANCTIONS}

See also: Foreign investment, Inter-state relations (China-Japan), (Non-)Interference, International economic relations (G-15, Myanmar), Nuclear energy matters

\section{US sanctions against Iran and Libya}

The US promulgated an act under which sanctions were to be imposed on foreign firms that invest $\$ 40$ million or more in the weapons production, the energy (oil) industry or the aviation capabilities of either country, both of which had been accused by the US of sponsoring terrorism. In case of violation of the prohibition the US president is directed to choose two of six possible sanctions: denying (US) Export-Import Bank loans, denying export licenses, barring US banks from making loans of more than $\$ 10$ million a year to the sanctioned party, barring sanctioned financial institutions from being primary dealers of US government bonds, banning US government procurement of goods and services from sanctioned entities, imposing import sanctions. The act allows the president to waive sanctions against foreign citizens whose countries impose their own sanctions. The act does not affect existing investments. The US had earlier banned trade by US companies with the two countries.(IHT 18 and 24-07-96)

The EU and Japan condemned the act vehemently.(IHT 18,24 and 25-07-96,06-0896)

On 12 August 1996 Turkey signed a \$20 billion contract with Iran for the construction of pipelines to eventually carry up to 10 billion cubic metres of natural gas a year to Turkey. Turkey insisted that the agreement dealt with trade, not investment, and consequently did not violate the US sanction law. It was said that each party would build its own side of the pipeline although Turkey might help the Iranian side by supplying materials in a barter deal.(IHT 13-08-96)

In early February 1997 the governor of the Iranian Central Bank divulged that Iran had managed to obtain offers of more than $\$ 5$ billion in government-backed loan guarantees from Europe, particularly Germany, and Japan, over the past 18 months, and that it had succeeded to reschedule about $\$ 22$ billion of its foreign debts: the shortterm debts were reduced from $76 \%$ in 1993 to $20 \%$. The loan guarantees did not technically violate the US sanction act because they were government-to-government commitments.(IHT 03-02-97)

\section{Sanctions against Myanmar}

(see: Association of South East Asian Nations, Inter-state relations)

On 30 September 1996 a US law, the Cohen-Feinstein Amendment, was signed, threatening a ban on all new US investments in Myanmar in case the government "has physically harmed, re-arrested for political acts or exiled Daw Aung San Suu Kyi, or 
has committed large-scale repression of or violence against the democratic opposition".

On 3 October 1996 the US introduced legislation declaring illegal the "formulating, implementing or benefiting from policies that are impeding the transition to democracy in Burma . . ."(IHT 04,5/6 and 07-10-96)

The US imposed a ban on new US investments in Myanmar in April 1997, under the 1996 legislation and after the US president had declared that "a state of large-scale repression" existed in the country. The sanction went into effect on 21 May 1997. (IHT 23-04,23-05-97;FEER 01-05-97:13)

It was reported in early November 1996 that the EU had banned entry visas for senior members of the ruling Council in Myanmar, their families and the military, while high-level governmental contacts were to be suspended. The EU had already withdrawn all diplomatic missions and halted development aid.(FEER 07-11-96:15)

On 18 December 1996 the Commission of the European Union called for Myanmar to be stripped of trade privileges accorded by the European Union, on grounds of alleged widespread use of forced labour. It also recommended the suspension of Myanmar from benefiting from the EU Generalized System of Preferences. The competent EU Council of Ministers decided accordingly late March 1997.

The EU move became inevitable when Myanmar in November refused entry to a coimmittee of experts to investigate allegations of forced labour.(IHT 19-12-96;FEER 03-04-97:57)

In April 1997 a US federal district court held that Unocal Corp., a US company doing business and making investments in Myanmar (see supra: Foreign investment) can be held liable for human rights abuses allegedly committed by the Myanmar government. The decision was being appealed.(IHT 18-04-97)

\section{Cancellation of F-16 sale to Indonesia}

It was reported that the US government was considering to cancel the sale to Indonesia of at least 9 F-16 fighter planes (see 6 AsYIL 339,449), as a response to the Indonesian crackdown on political dissent in July 1996 (the 'Democratic Party incident'). Reacting to the US delay of the sale the Indonesian government said it did not bother, since the purchase was not a priority.(IHT 22-08,7/8-09-96;FEER 29-0896:12, 19-09-96:13)

The cancellation was confirmed by Indonesia on 6 June 1997, which also announced pulling out of a US-sponsored military education and training program (International Military Education and Training scheme, 'Imet'). The decision was motivated in part by the 'wholly unjustified criticism' of Indonesia in the US Congress.(IHT 7/8-06-97;FEER 19-06-97:16)

\section{US export license for North Korean barter deal}

A US company was given permission by the US Treasury to export 500,000 tons of food to North Korea as part of a barter transaction.(IHT 07-01-97) 


\section{EU ban on arms sales to China}

Since the Tiananmen incident in 1989 an embargo had been imposed by the EU on arms sales to China. The French defence minister visited China in early April 1997. He called for a 'strategic dialogue' and expanded military ties, highlighting the question of the eventual lifting of the sanction.(AsT 09-04-97)

Since the arms ban was imposed unanimously, its lifting requires the same kind of decision. Yet, even with the embargo still in place, most EU member states interpreted the ban to mean a ban on lethal weapons, in contradistinction to other equipment.(FEER 24-04-97:25)

\section{Sanctions on the sale of chemical weapons technology}

On 22 May 1997 the US announced it would punish two Chinese companies and one Hongkong company for selling chemical weapons technology (precursors) to Iran, by banning them from US government trade for at least a year. The sanction was applied under the 1991 Chemical and Biological Weapons Control Act for "knowingly and materially contributing to Iran's chemical weapons program". Companies in other countries - Australia, Austria, Germany, Italy and Thailand - had been punished for similar violations. China protested and demanded cancellation of the sanctions.(IHT 23-05,24/25-05-97)

\section{SEA AND SEA TRAFFIC}

\section{US response to Chinese declaration on passage of warships}

It was reported that the US advised China by diplomatic note of 21 August 1996 that it regarded the territorial sea baselines determined in the Chinese declaration of 16 May 1996 on the matter ( $c f .5$ AsYIL 211 n.5) to be contrary to international law. Consequently the US rejected the Chinese restrictions of free navigation by foreign warships in waters that would be part of the high seas but for the Chinese baselines. These Chinese restrictions were contained in its 1992 Law on the Territorial Sea and the Contiguous Zone and the May 1996 declaration (see 2 AsYIL 165 and 5 AsYIL 225).(IHT 19-09-96)

\section{Thai contiguous zone}

It was reported that the Thai decision to establish a contiguous zone in the Gulf of Thailand (by way of implementation of the 1995 Royal Proclamation, see 6 AsYIL 228) caused surprise in Cambodia because it and Vietnam were still engaged in discussions with Thailand on overlapping claims.(FEER 20-02-97:12)

\section{US attitude toward Strait of Hormuz}

As Iranian air and naval forces began exercises in the Gulf, the commander-inchief of the US Central Command said that the US would take immediate action to defend the Strait against any Iranian threat to close the waterway.(IHT 12-05-97) 


\section{SOCIAL MATTERS}

\section{Asian welfare ministers meeting}

Social welfare ministers from East and Southeast Asia met on 5 December 1996 in Japan and agreed to hold a high-level meeting in 1997 to promote exchanges of knowledge and ideas on social welfare, particularly in the fight against AIDS and in view of aging-society problems. They also agreed on the need to establish an international system to collect information on infectious diseases and promote exchanges of trainees and specialists.

The meeting was attended by ministers from Brunei, Cambodia, China, Indonesia, South Korea, Laos, Malaysia, The Philippines, Singapore, Thailand, Vietnam and Japan.(AsahiEN 06-12-96)

\section{SOUTH ASIAN ASSOCIATION FOR REGIONAL CO-OPERATION (SAARC)}

\section{Summit Meeting in Maldives}

At the ninth summit meeting that ended 14 May 1997 the seven leaders conceded their failure to curb hostilities that had set the pattern of relationships in the region for the past fifty years. Trade between the seven member states accounted for barely 1 percent of total world trade while the population constituted 20 percent of all mankind.(IHT 15-05-97)

\section{Target year for implementation of SAPTA}

At the Maldives summit meeting the member states moved their target year for free trade under the 1993 "Agreement on SAARC Preferential Trading Arrangement" (see 3 AsYIL 481) to 2001 from the earlier target year of 2005.(IHT 15-05-97)

\section{SPECIFIC TERRITORIES IN A STATE: EAST TIMOR}

See also: Association of South East Asian Nations

\section{Nobel Peace Prize for East Timorese}

The Nobel Peace Prize for 1996 was awarded on 11 October 1996 to the Roman Catholic bishop of East Timor, CARLOS F.X. BELO and J.RAMOS-HORTA, a spokesman of one of the resistance movements in East Timor. The prize was received on 10 December 1996.(IHT 12/13-10,11-12-96)

\section{EU action}

The European Union in a declaration of 15 December 1996 repeated calls for Indonesia to improve its human rights record in East Timor. In November the Indonesian ambassador to the EU told Europe to keep out of the East Timor issue and warned that European measures there could have 'grave repercussions'.(JT 16-12-96) 
SPECIFIC TERRITORIES WITHIN A STATE: KASHMIR

See: Inter-state relations (India-Pakistan)

SPECIFIC TERRITORIES WITHIN A STATE: TIBET

See: (Non-)Interference

\section{STATE SUCCESSION}

See also: Air traffic and transport

\section{Assumption of former South Vietnamese debts by Vietnam}

After several years of negotiations an agreement was reached between Vietnam and the US on 8 March 1997 under which Vietnam agreed to take over debts incurred by the former South Vietnamese government vis-à-vis the US for roads, power stations and grain shipments. Most of these debts were incurred to bolster South Vietnam's war effort and involved an amount of about $\$ 140$ million. The debt is to be repaid within 20 years. Vietnam refused to repay $\$ 12$ million in outstanding loans for the 'Food for Peace' program, arguing that through a series of complex transactions the US used money that was earmarked for grain purchases, to help finance the Vietnam War.(IHT 12-03-97)

Under the 1993 so-called Paris Club agreement, Vietnam agreed in principle to assume government-to-government debts of the former South Vietnamese government.(FEER 20-03-97:13)

\section{TAXATION}

\section{Thai - US double taxation agreement}

The two countries concluded an agreement to prevent double taxation for citizens of one side doing business in the other. The treaty concluded three decades of dispute.(IHT 26-11-96;JT 27-11-96)

\section{TECHNOLOGY}

See: Military co-operation (China-US)

\section{TELECOMMUNICATIONS}

\section{Coincidence of orbital slots of satellites}

Indonesia had reportedly complained to China that the Chinese APT Satellite company had put its APTStar 1A broadcast satellite into an orbital slot above longitude 134 degrees east, the same spot registered by Indonesia for its Palapa Pacific 1 satellite in October 1993. A relevant complaint would be made to the ITU.(FEER 21-1196:14) 


\section{TERRITORIAL CLAIMS AND DISPUTES}

See also: Fisheries

\section{Chinese monument at Paracel Islands}

A Chinese archeological expedition to the Paracel Islands in May 1996 erected a 'cultural relics protection monument' on a reef where ships in the Song dynasty had capsized and spilled their cargoes of pottery. It was said that the monument was meant to show that the site was under the jurisdiction of Hainan province.(FEER 11-0796:28)

\section{Dispute over the Senkaku (Diaoyu) Islands (see also: (Non-)Interference)}

In July 1996 a rightist Japanese group, Nihon Seinensha (Japan Youth Federation) built a makeshift lighthouse on Kitakojima, one of the disputed Senkaku (Diaoyu) Islands to bolster Japan's claim to the territory. In August 1996 Japanese rightists planted a flag and erected a war memorial on the islands.

The five islands and three reefs are situated about 200 kilometres north-east of Taiwan and 300 kilometres west of the island of Okinawa, and are surrounded by rich fishing grounds and potentially lucrative reserves of oil and natural gas. China claims the islands on historical grounds dating from the 16th century, but according to Japanese officials China and Taiwan showed little interest until an academic UN study in 1978 (1968?) showed the possibility of oil and gas nearby. Japan bases its claim on annexation in 1879 as formalized by treaty in 1895 .

The islands were occupied by the US after the war and turned over to Japan in 1972, together with Okinawa. On that occasion the US said that any outstanding territorial issue should be settled among the countries concerned. From Taiwanese perspective the islands fall under Ilan County jurisdiction. Taiwanese fishermen live closest to the islands and it was estimated that Taiwanese ships bring in about 40,000 tons of fish a year from nearby waters within the Taiwanese EEZ.

In 1978 the then Chinese leader suggested that the sovereignty issue be put aside and that the islands be developed co-operatively.(IHT 20/21-07-96,01 and 22-0896,17-09-96,16-10-96;FEER 19-09-96 p.14-15;JT 26 and 27-09-96)

The incident sparked a strong official Chinese reaction and popular protest, most strongly in Hongkong and Taiwan. Early September a Japanese Coast Guard patrol blocked a Taiwanese vessel from reaching one of the islands, and Japan also lodged an official protest with China after a Chinese ocean research vessel entered the territorial waters of the islands without permission.

While China is of the opinion that the dispute over sovereignty will "require a long time to resolve", it held that the Japanese government had to "stop construction of the illegal facility by a Japanese group". Japanese sources said that the government could not order the tearing down of the lighthouse because it stood on what is officially viewed as private land on an island claimed by Japan as its territory. The Japanese prime minister referred to the limits what the government of Japan could do "as a law-governed state". 
In an effort to soothe bilateral tensions the two countries discussed the matter in high-level talks between the foreign ministers during their presence in New York during the UN General Assembly meeting in late September.

The Japanese foreign minister promised his Chinese counterpart on 24 September 1996 that Japan would refrain from officially recognizing (registering) the lighthouse as an official one in spite of an application to that effect by the group concerned and by fishermen on Ishigaki Island, Okinawa Prefecture. This policy was affirmed by a government decision in early October. Under the Japanese navigational beacon law, the Maritime Safety Agency has authority to grant official recognition to privately built lighthouses.(IHT 7/8 and 20-09-96,5/6-10-96; AsahiEN 04-10-96;JT 26 and 2709-96,05 and 31-10-96)

In spite of the above restraints China kept urging Japan to take measures to cool down the territorial dispute, warning that a do-nothing policy would hurt China's feelings and undermine bilateral ties. The foreign ministry spokesman said that China "still hopes to shelve the dispute and jointly develop (the region)"(JT 10-10-96)

During an annual Sino-Japanese vice-ministerial meeting in late October 1996 the two countries agreed to resolve the territorial issue in a calm manner although there were no major developments overr the question of sovereignty. Japan repeated its assertion that no territorial issue exists because the islands historically belong to Japan.(AsahiEN 30-10-96)

The anger of China and Taiwan was again provoked when a Japanese member of Parliament traveled to the islands in early May 1997, declaring it his duty to inspect Japanese territory.(IHT 07-05-97) In late May there was a flare-up of the dispute when Japanese coast guard ships blocked 28 protest boats with Hongkong and Taiwan protesters from approaching the islands, and allegedly damaged some of them.(IHT 27-05-97)

\section{ASEAN attitude toward Chinese claims to South China Sea areas (see also: Association of South East Asian Nations)}

It was reported that the ASEAN foreign ministers during the post-ministerial meeting with China in July 1996 (supra p.397) collectively expressed their opposition against the Chinese declaration of May 1996 on the delimitation of the territorial sea around the disputed islands (see AsYIL Vol.5:219, Vol.6:459).(IHT 22 and 25-07-96)

At the dialogue meeting of April 1997 held at Huang Shan, China for the first time agreed to talk about the contrasting territorial claims in the South China Sea in a multilateral context.(FEER 08-05-97:15)

\section{Sino-Philippine disagreements over Spratly Islands}

During the APEC summit meeting at Manila in November 1996 the Chinese and Philippine presidents discussed the islands disputed by their countries. It was reported that the Chinese president proposed the "joint development of the resources beneath the islands, reefs and shoals".(IHT 27-11-96)

On 25 December 1996 the Philippines opened a runway on one of the disputed islands, pledging to develop the area as a tourist destination. The eight-island Kalayaan group, a cluster of largely uninhabited isles, shoals and reefs claimed by the 
Philippines, are a part of the Spratly Islands. The Philippine move was criticized by China.(IHT 26 and 31-12-96)

The Philippines proposed to include the issue of the Spratly Islands in the agenda of a meeting of the US-Philippine mutual defence board in December 1996, but the proposal was rejected by the US.(IHT 11-12-96)

In late April 1997 the Philippine government launched a protest over the entry of three Chinese frigates into an area of the Spratly Islands claimed by the Philippines. The vessels were spotted on 25 April 1997 close to Kota and Panata islands. The two islands lie between Pagasa, which was occupied by the Philippines, and Mischief Reef, claimed by the Philippines and occupied by China. Besides the Philippine armed forces reported that it had discovered a new hut-like structure built over a reef 6 miles northeast of Kota island, without saying who had built the structure.(IHT 30-04-97) The chairman of the Philippine Senate Foreign Relations Committee urged the government to seek help from the US to have China withdraw the vessels. On 2 May 1997 it was reported that the ships were withdrawn from the area concerned.(IHT 03/04-05-97)

It was reported that the Philippines on 25 June 1997 ordered its troops to avoid using weapons in driving Chinese fishing boats away from isles occupied by the Philippine forces. The Philippine forces had fired warning shots a week before when Chinese fishing boats came near Kota Island.(IHT 26-06-97)

\section{Scarborough Shoal / Huangyan Island}

On 20 May 199721 Chinese fishermen were arrested by the Philippine navy near what is referred to in Western sources as Scarborough shoal and called Huangyan island by the Chinese, about 215 kilometres off Zambales Province on the Philippine island of Luzon. They were to be charged with illegal entry and poaching in the Philippine exclusive economic zone. The Chinese embassy protested since, it said, the area belonged to China. This and other disputes over South China Sea islands between China and the Philippines were among the issues in bilateral talks on 26 May.(IHT 27-05-97;FEER 29-05-97:13)

The importance of the island lay in the surrounding fishing grounds and possibly oil-rich seabed. The Philippines pointed out that the island is within its exclusive economic zone, and that the island was used for target practice by the Americans when they operated bases in the Philippines. On the other hand, the Chinese foreign ministry said the island had been Chinese territory since ancient times. China had claimed the island as its territory in documents published in 1935, 1947 and 1983, and had reaffirmed them since. It bases its right to the surrounding waters on its title to the island(s). As the Chinese embassy in the Philippines said, "[t]he land dominates the sea is a basic principle of international law. ... Maritime rights and interests do not generate territorial sovereignty".(FEER 05-06-97:40,12-06-97:17) 


\section{Natuna Islands and Natuna gas field}

(see: 5 AsYIL 500)

In order to assert its sovereignty Indonesia held its largest air, land and sea manoeuvres in four years in the area.(FEER 19-09-96:17)

\section{Sipadan and Ligitan Islands}

(see: 6 AsYIL 460)

Indonesia and Malaysia agreed on 7 October 1996 to submit their dispute on sovereignty over the two islands off the east coast of Borneo to the International Court of Justice. The two countries had tried unsuccessfully to resolve the issue through diplomatic and political channels for the past five years. Each side would appoint an official of ministerial rank to speed along the matter.(IHT 08-10-96; AsahiEN 08-10-96; FEER 17-10-96:14; JT 01-12-96)

\section{Japan-Russia island dispute}

(see: AsYIL Vol.1:346, Vol.2:376, Vol.3:448, Vol.4:512, Vol.5:499, Vol.6:461)

The two countries reaffirmed at the sixth round of sub-Cabinet-level talks on 2 October 1996 the importance of resolving the long-standing territorial row over the Northern Territories and concluding a bilateral peace treaty.(AsahiEN 03-10-96)

However, it was announced on 9 October 1996 that the Russian president had approved a basic document on border policies, including rejection of any territorial claim against Russia.(Daily Yomiuri 10-10-96)

\section{Japan waives claim to southern Sakhalin}

In a major shift in its territorial policy Japan was to accept Russia's control of the southern half of Sakhalin Island by setting up a branch consulate at YuzhnoSakhalinsk in spring 1997. By setting up the consulate Japan hoped to normalize its relations with the Sakhalin provincial government, which has jurisdiction over the four disputed islands off Hokkaido.

[In the 1951 Peace Treaty japan renounced all rights to the Chisima Islets, located between the four disputed islands and the Kamchatka Peninsula. But Japan did not acknowledge Soviet sovereignty as it might affect the territorial dispute, and consequently the Soviet Union did not participate in the Treaty. In October 1995 a Japanese diplomat visited southern Sakhalin for the first time. In September 1996 the Japanese government opened a Japan Center in Yuzhno-Sakhalinsk.](JT 02-12-96)

\section{Takeshima/Tok-do islands} (see: 6 AsYIL 460)

The Japanese foreign ministry filed a request with the South Korean embassy in Tokyo on 31 October 1996 for halting the construction of harbour facilities on the disputed islands that had been under way since February 1996.

However, a spokesman of the Korean foreign ministry said: "Our government rejected the Japanese call, stressing that Tok-do is an inherent territory of South Korea both historically and under international law." 
The uninhabited 'Takeshima' or 'Tok-do' islets which have a total area of 23 hectares, lie halfway between Japan and South Korea in the Sea of Japan.(JT 03-1196;FEER 14-11-96:15)

In December 1996 it was reported that the Korean government had decided to solidify South Korea's claim by building a manned lighthouse that would be completed in 1998.(JT 13-12-96)

\section{Chinese attitude toward Indian control of Sikkim}

The Indian foreign minister said that it was his impression that China was moving toward conceding India's take-over of Sikkim in 1975.(IHT 17-12-96)

\section{Sino-Vietnamese dispute over oil exploration in disputed areas}

In March 1997 Vietnam demanded that China stop drilling for oil close to the Spratly Islands, as it violated Vietnam's sovereignty over its exclusive economic zone and continental shelf. On 7 March 1997 a Chinese exploration rig, the 'Kantan III', had been moved to a place in a portion of the Song Hong Basin in the South China Sea, an area designated by the Vietnamese as Block 113 for exploration purposes.

The disputed zone lies south of the Tonkin Gulf, almost equidistant from the central-Vietnamese coast (65 miles) and the Chinese island of Hainan (75 miles), about 600 miles north of the Spratlys. It is also claimed by China to be part of its continental shelf and exclusive economic zone, and was not covered by regular bilateral talks on either contested areas in the South China Sea, or disputed areas further north in the Gulf of Tonkin. The area lies some 50 kilometres west of the Yacheng deposit, where China was already drilling for gas in partnership with the Atlantic Richfield oil company of the US.

Early April 1997 the director of the maritime department of the Vietnamese border commission had said that the platform and its support boats were withdrawn on 1 April. This was denied by the Chinese side, but on 7 April 1997 the China National Offshore Oil Corp.(CNOOC) said that the exploratory oil rig was withdrawn from the disputed area.(IHT 17-03,21-03,28-03,5/6-04,08-04-97;FEER 03-04-97:14;ST 08-0497)

Both parties agreed to discuss the disagreement, and Vietnamese and Chinese experts started to hold talks on 9 April 1997 in a bid to determine who controls the area. Earlier, however, Vietnam briefed ASEAN on 20 March and enlisted support from its fellow member-states. The incident was raised at a third meeting of senior officials of ASEAN and China (as an ASEAN 'dialogue partner'), held at Huang Shan, China, in April 1997. China acknowledged that the South China Sea was an important component in ASEAN-China relations, and offered to insert a code-ofconduct clause, referring to the peaceful settlement of disputes in the sea, in a joint political declaration.(IHT 02-04,04-04-97;FEER 03-04-97:14,01-05-97:12;AsT 08-0497)

\section{Singapore - Malaysia}

The Malaysian railroad company, KTM Berhad, owns over 200 hectares of land in Singapore on a 999-year lease, most of it on either side of a rail line from downtown Singapore to Kuala Lumpur. The Malaysian side accuses Singapore that the latter was 
pressing Malaysia to give up the land and to move its train station to the suburbs. Singapore, on its part, said that Malaysia backed out of a 1990 agreement on such transfer. It was reported in March 1997 that KTM was to take legal action to evict people who were occupying parts of the land.(IHT 28-03-97;FEER 05-06-97:24)

\section{TERRORISM}

See: Civil war

\section{TRANSIT}

See also: Rivers

\section{Transit rights for Nepal}

India agreed to let traders from Nepal to cross its territory to reach ports in Bangladesh. So far the only access to the sea was through the Indian port of Calcutta. Transit through a land corridor across northeastern India using the 60 (70?)-kilometre Kakkarbhitta-Phulwari (Kakarvitta-Banglabandh?) route would cut transport costs and shipping delays in Calcutta. The route was opened in June 1997 on a trial basis for six months.(IHT 15-08-96,FEER 19-06-97:13)

\section{UNITED NATIONS}

See also: Divided states: China, Non-aligned Movement

\section{Japanese attitude}

In his speech to the UN General Assembly on 24 September 1996 the Japanese prime minister outlined his vision of Japan assuming a leading role in the world's political and economic affairs through the UN. He expressed disappointment over the lack of progress in efforts to reform the organization. He reiterated Japan's proposals for carrying out reforms 'in a balanced manner' in three areas: reforming the UN Security Council, streamlining financial and administrative structures, and strengthening global social and economic development programs. He stressed that such reforms are needed for Japan to assume a leading role, including a permanent seat on the Security Council.

The prime minister repeated that Japan "is prepared to discharge its responsibilities as a permanent member of the Security Council" in accordance with its basic philosophy of abstaining from the use of force, which is prohibited by its Constitution.(JT 26-09-96)

\section{Review of role and composition of the World Court}

Through its representative at the UN, Malaysia had called for a review of the role and composition of the International Court of Justice. The representative said that the credentials of aspiring candidates to the court should be scrutinized instead of endorsing them on the basis of geopolitical considerations.(JT 17-10-96) 


\section{India and Japan compete for Security Council seat}

On 21 October 1996 Japan was elected to a non-permanent seat for the 1997-1998 period, defeating India by 142 to 40 votes.(JT 23-10-96) Japan's election was its eighth; India has served six turns on the Council.(FEER 31-10-96:13)

\section{Representation of Afghanistan}

In the United Nations a decision on the credentials of the Afghan delegation was deferred on 11 October 1996, despite a challenge from the Taleban. The representatives of the ousted president RABBANI consequently retained their seat for the time being.(IHT 12/13-10-96)

On 17 November 1996 the Taleban authorities asked the UN to recognize it as the legitimate authority in Afghanistan and to grant it the seat of Afghanistan.(IHT 18-1196)

\section{Motivation for use of right to veto}

China had vetoed a UN Security Council resolution on the deployment of UN peace-keeping forces to Guatemala for the implementation of an agreement to end the civil war in that country. According to the government spokesman China had used its veto because of Guatemala's long-standing diplomatic recognition of [the government of] Taiwan and its support for Taiwan's bid to rejoin the UN. Although China had no objection to the principle of sending UN monitors, he said: "we had no choice". ... "Clearly, the government of Guatemala must be responsible".

It was the first time in 24 years that China had used its right to veto in a matter outside the selection of a secretary-general.(IHT 13-01-97;FEER 23-01-97:13)

In view of a subsequent Guatemalan change of its Taiwan policy China and its promise to cease support to Taiwan's attempt to enter the UN, China reversed its position 10 days later and voted in support of sending the peacekeeping mission.(FEER 06-02-97:30)

\section{UNRECOGNIZED ENTITIES}

See also: Inter-state relations (China-South Africa, China-US)

\section{Japan - Taiwan}

According to a Taipei newspaper the Taiwanese authorities would cancel some privileges enjoyed by Japan's de facto diplomats to reciprocate for Japan's refusal to upgrade treatment of Taiwan's unofficial representatives in Japan. Japan's representatives would be stripped of tax exemptions and their car registrations would be downgraded to those of foreign organizations rather than diplomats.(AsahiEN 03-1096)

\section{US - Taiwan}

On the occasion of a visit to Taiwan the US deputy Treasury secretary said that the economic ties between the US and Taiwan were becoming increasingly close. It 
was the highest-level US mission to Taiwan since the transport secretary made a visit in 1994.(IHT 16 and 18-09-96)

\section{North Korea - Taiwan}

It was reported in July 1996 that North Korea planned to set up a representative office in Taiwan by the end of the year to enhance economic ties and encourage investment. It had already an office in Taipei since April 1996 to issue travel certificates.(FEER 15-08-96 p.13)

\section{WEAPONS}

See also: Disarmament, Nuclear energy matters

\section{China against ban on landmines}

China opposed a total ban on anti-personnel landmines when the issue was discussed in the Disarmament and International Security Committee of the UN General Assembly on 18 October 1996. The Chinese representative said that especially to countries with a long land-border landmines remained an effective weapon of selfdefence. He referred to the Chinese experience with the use of landmines in its war against Japan.(JT 20-10-96)

\section{Comprehensive nuclear test ban treaty}

It was reported on 26 October 1996 that 129 countries had signed the treaty, including all but three of the state that must sign and ratify it before it could enter into force. The three are North Korea, India and Pakistan.

The treaty stipulates that 44 states known to have nuclear reactors and research programs must sign and ratify before the treaty can enter into force 180 days after ratification by the 44 states. Only Fiji had ratified.(JT 27-10-96)

\section{WORLD TRADE ORGANIZATION (WTO)}

See also: Asia-Pacific Economic Co-operation, International economic relations

\section{The issue of China's admission}

China and the US again discussed the issue of China's admission to the Organization. The Chinese trade minister said that China was prepared to show greater flexibility in upcoming negotiations over China's acceptance, but that China should be admitted under the more lenient rules for developing countries. The US, on the contrary, was of the opinion that China should meet a stricter standard, taking into account its huge economy. The Chinese minister said: "If the admission fee is too high, we cannot afford it. I do not have so much money in my pocket."(AsahiEN 28-09-96)

Japan and some European countries had criticized the US for demanding that China make too many market-opening reforms before it is granted WTO membership. The US responded to that criticism by accusing other countries to let the US take the lead rather than risk offending China.(JT 16-11-96) 
The Chinese foreign minister said in November 1996 that China hoped to conclude talks with the US on China's membership by mid-1997.

It was reported meanwhile that among the reasons of the continuing stalemate was the absence of consensus in either country on the desirability of Chinese membership and its consequences.(IHT 26-11-96)

\section{Agreements at quadrilateral meeting}

Trade ministers from Japan, the US, Canada and the EU agreed on setting up a working committee in the WTO to discuss issues left unsettled under the Uruguay Round, such as the issue of investment rules.

The ministers argued that the WTO should keep in close touch with the ILO on the issue of permissibility of import restrictions on goods manufactured in countries with poor labour conditions.

The ministers also discussed the proposals for an Information Technology Agreement which would eliminate tariffs on semiconductors, computers and similar products by the year 2000.(JT 29-09-96)

\section{The case of the Indonesian 'national car' policy (the 'Timor' case)} (see: 6 AsYIL 416)

An Indonesian national car policy which was introduced in February 1996 granted an exclusive three-year exemption from import duties and luxury taxes to a joint venture between an Indonesian car company and Kia Motors Corp. of South Korea.

The policy was challenged as an unfair trade barrier. The European Union filed a complaint on 3 October 1996 with the WTO, followed by Japan on 4 October 1996 and by the US on 13 June 1997.

Specifically Japan charged Indonesia on three main points: the duty-free import from South Korea violates most-favoured nation treatment, exempting luxury tax discriminates against foreign car manufacturers (Art.I GATT), and linking local contents with tax incentives violates trade-related investment rules.(AsahiEN 03-10-96;JT 0510-96; IHT 16-06-97)

[The Uruguay Round resulted in, inter alia, an Agreement on Trade Related Investment Measures. This agreement, to which Indonesia was a party, containes a 'standstill' provision, under which signatories were barred from implementing new investment measures after January 1995. Indonesia argued that its measures represented a mere modification of a 1993 national car policy that predates the Agreement and had been duly reported to GATT.]

Consultations in bilateral form at the request of Indonesia started on 1 November 1996. As no accord was reached on 3 December 1996 (i.e. within sixty days), the claimant could ask for the creation of a WTO panel that would have to deliver a ruling within nine months.(JT 31-10,05-12-96;FEER 17-10-96:97)

The WTO agreed in June 1997 to create a panel to look into the complaints.(IHT 13-06-97) 


\section{US vs. Japan over Japanese photographic film and paper market}

The US in June 1996 had called for Japan to accept bilateral consultations, in accordance with a 1960 GATT decision, on alleged restrictive business practices in the photographic film and paper market. The US complained that the Japanese government was blocking foreign access to the local market through restrictive laws. Japan replied that it would agree to the talks, but only on condition that the US accept similar talks on business practices in the US film market.

The US did not accept the condition and instead it filed a request for a panel with the WTO in August-September 1996. Japan rejected the establishment of a panel in a 3 October meeting of the WTO Dispute Settlement Body on grounds that the US claims lacked specifics. However, the panel was automatically set up under WTO rules on 16 October. It was expected to deliver its verdict in spring 1997. The EU reserved its right to take part in the proceedings.

The dispute took place against the background of a struggle between Eastman Kodak Co. and Fuji Photo Film Co. to penetrate each other's markets. Kodak holds $36 \%$ and Fuji $33 \%$ of the global market in photofilm. Kodak argued that Fuji blocked Kodak's access to the Japanese market through anti-competitive practices in collaboration with the Japanese government. In 1995 it lodged a petition with the US government under Section 301 of the US trade law. After 11 months of investigation the US government decided to freeze the 301-process and to take the case to the WTO.

The US blamed Japanese laws, such as the Large-Scale Retail Stores Law and the Premiums Law, for blocking Kodak's access to the local market in violation of the GATT and the GATS (General Agreement on Trade in Services). The law allegedly limited the number and size of large retail stores, resulting in an unfairly limited volume of imports. Fuji denied the allegations and, on its part, accused Kodak of unfair business practices impeding Fuji's access to the US market.(IHT 14-08-96; AsahiEN 03-10,16-10,17-10-96; JT 17-10-96)

\section{India/Malaysia/Pakistan/Thailand vs. US on shrimp imports}

The US Court of International Trade found in favour of an environmental group which had complained that many imported shrimps were caught with methods that were harmful to sea turtles, an endangered species. The Court ruled that so-called wild shrimps, caught at sea by ships not using devices or techniques to protect turtles, could not be imported into the US. The ban came into force in May 1996.

Asian countries which were heavily engaged in marine shrimp fishing, were especially badly hit by the decision which, they argue, effectively sought to impose US environmental law on other countries. The US National Fisheries Institute had estimated that the ban would block between $\$ 200$ to $\$ 500$ million worth of shrimps, or about $25 \%$ of all imports into the US.

India, Malaysia, Pakistan and Thailand launched a case against the US over the ban. The four countries sent a letter to the US mission to the WTO asking for consultations on the issue. The US would have ten days to reply, and would have to start consultations within 30 days. If no solution were reached within this period, the claimants could ask for the creation of a full dispute panel. If the panel ruling and eventual appeal ruling would go against the US, the ban would have to be lifted or compensation paid for the value of lost trade. 
The current WTO procedure (Understanding on Rules and Procedures governing the Settlement of Disputes) had replaced the old GATT procedure under which any country could block approval of a panel decision by preventing consensus.(JT 10-1096)

\section{European Union vs. Japan on shipping practices}

The EU has called for consultations under Article VIII of the GATT with Japan on allegedly unfair Japanese harbour practices: a monopoly on stevedore services by the Japanese Harbor Transportation Authority (JHTA) allegedly resulted in discrimination of European ship operators.

Shipping lines wishing at short notice to change the docking schedules of their vessels at Japanese ports could not do so as loading and unloading 'slots' were controlled entirely by the JHTA, which allocated stevedores to vessels on a rota basis. In comparison, once a vessel was given a slot at a EU port, shipowners could negotiate with stevedores for the best rates. The Japanese stand was that as the stevedore business was privately run, the government had no say in the matter.(AsahiEN 15-10-96)

\section{US/EU/Canada vs. Japan on liquor tax}

An appellate panel delivered a ruling in this case on 4 October 1996, deciding against Japan. It found that Japanese taxes on shochu (distilled spirits) were too low and urged Japan to narrow the tax-rate gap between shochu and other spirits, such as whiskey and vodka. Japan had already been forced to rectify its liquor taxation rules in 1989 and 1994, following a 1987 ruling by the GATT, but taxes on whiskey were still six times higher than those on shochu.

A special meeting of the WTO was called by the EU to adopt the ruling, but the meeting was suspended at the request of Japan because only 35 of the 125 member countries of the dispute settlement body were represented at the meeting, less than the required simple majority of 63. [Usually business was proceeded even lacking a quorum. An appellate report is automatically adopted 30 days after its distribution, unless there is a consensus against adoption] (JT 17-10-96,31-10-96) The ruling was later declared adopted on 1 November. Japan was expected to inform the dispute settlement body within 30 days of its intention to comply with the ruling and to implement the recommendations within 18 months.(JT 02-11-96) The notification of acceptance took place later in the month.(AsahiEN 21-11-96)

\section{Japan-US dispute on alleged Japanese dumping}

Japan was considering filing a complaint with the WTO against the US over the latter's unilateral action regarding alleged dumping of supercomputers by NEC and of printing press systems by Mitsbishi and other Japanese companies.(JT 23-10-96)

[NEC Corp. of Japan was accused by Cray Research Inc. of the US of having unfairly won a \$35 million contract from the (US) National Center for Atmospheric Research to supply weather-forecasting computers by 'dumping' its supercomputer. The US Commerce Department accordingly started an investigation.](FEER 08-08-96:65;JT 31-10-96) 


\section{Japan-US dispute over access for imported goods in Japanese markets}

The US had complained to the WTO about Japanese laws restricting the number of large stores as one of the best outlets for imported goods. Subsequent discussions under the auspices of the WTO in November 1996, however, had failed to produce any agreement.(JT 10-11-96)

\section{Disagreement between developed and developing countries over issues to be dealt with by the WTO}

Asian and African states, including Japan, rejected efforts by the US and some western countries in November 1996 to include the issue of labour standards in the agenda of the WTO and to have it discussed at the WTO ministerial conference to be held at Singapore in December 1996. A similar rejection was demonstrated against efforts to start WTO talks on global rules for investment. The developing countries feared that discussion of these issues would inevitably lead to binding rules that could then be enforced through the WTO's dispute-settlement mechanism. They argued that the labour standard issue was essentially a protectionist device, while the issues of investment rules and competition policy were aimed at enabling Western and Japanese companies to control the markets of developing countries. Labour matters should be handled by the ILO. Other proposals for the WTO agenda included the impact of regional groups on global trade, the updating of existing anti-dumping rules, worldwide regulations to ensure free and fair competition, business corruption. As to the connection between trade and investment and between trade and competition, a number of developing countries, among which India and Pakistan, preferred the relevant studies to be carried out by the UNCTAD.(JT 24-11-96;IHT 09 and 12-12-96;FEER 04-07-96:69)

\section{WTO and anti-dumping}

Less than a week before the first WTO ministerial conference in December 1996 the Japanese chief trade negotiator said that WTO should not limit itself to investigating competition policy, but should also look into abuses of anti-dumping measures, which also distort international trade. He thus referred to two sides of the issue: competition policy affecting trade and trade measures affecting competition policy. This attitude was in conformity with the South Korean position but in contradistinction to those, such as the US and Europe, who insisted on a 'partial approach', focusing on competition policy.(JT 05-12-96)

\section{Information Technology Agreement (ITA)}

The US had been pushing hard for an agreement to remove tariffs by 2000 on the information technology industry at the first ministerial meeting of the WTO in December 1996. But some developing countries, particularly in Asia, were not convinced that free trade in these products would benefit them and were of the opinion that a deal must extend to cover lower technology consumer goods such as television sets which they produce.(JT 07-12-96) Besides, these countries worried about the consequences of the slash of tariffs for their industrial policy: the advent of global trading without impediment would curb nascent national industries.(FEER 12-1296:60) 
Agreement was finally reached on abolishing tariffs on trade in computers, chips, software and telecommunications equipment by the year 2000. Among the Asian countries adhering to such tariff-cuts were Japan, Hongkong, Indonesia, South Korea, Singapore, and Taiwan.(IHT 13-12-96)(see infra) On 4 March 1997 the WTO announced that it expected a formal agreement shortly. The first round of tariff cuts was scheduled for 1 July 1997.(IHT 05-03-97)

\section{Rejection of address by ILO Director General}

An invitation to the Director General of the ILO to address the WTO ministerial conference, extended by the Swiss chairman of the WTO General Council, was withdrawn after complaints by developing countries. These countries argue that the West wanted working conditions to be subjected to trade rules to undermine the poorer countries' advantage from lower wage costs.(see infra) Meanwhile the ICFTU stepped up pressure on the WTO to enforce human rights in workplaces, joining western criticism against poorer countries opposing the proposal.(JT 07-12-96)

\section{Results of First Ministerial Conference}

A ministerial declaration adopted on 13 December 1996 at the end of the first ministerial conference of the WTO at Singapore endorsed an Information Technology Areement to scrap tariffs on the market of computer-related products. The declaration did not cover telecommunications. While Japan, Taiwan and the Philippines welcomed the effort to lessen trade restrictions in this field, China was said to be against.

The declaration rejected the use of labour standards for protectionist purposes and referred to the ILO as the competent body to deal with the issue of these standards.

There was also agreement on an action plan to boost trade with the world's least developed countries.

The conference also decided to create two new groups to study treatment of foreign investment and competition.(JT 14-and 15-12-96)

\section{WORLD WAR II}

\section{Right of comfort women to sue the state of Japan}

In view of the reluctance of many former 'comfort women' to receive payments from the Japanese government-sponsored 'Asian Peace National Fund' ('Asian Women's Fund'), the Japanese government indicated that such payments would be completely separate from the legal issues involved and that it would not bar ("does not discourage") the women's groups from taking their cases to court. Those who rejected donations from the 'private' Fund had insisted on direct compensation from the Japanese government.

The official Japanese stance is that Japan need not compensate anymore because the issue had already been legally resolved with the respective governments (see 6 AsYIL 468).(MainichiDN 12-10-96;JT 17-10-96;FEER 25-07-96:26) 


\section{Aid to former Indonesian 'comfort women'}

It was reported that the Japanese government was to give 380 million Yen over a ten-year period to provide help for Indonesian women forced to work as sex slaves during World War II. The money would not be given directly to the individuals concerned but would be handled by the Indonesian government.

Historians estimated that some 60,000 Indonesian women were forced into sexual slavery, but so far only around 300 had contacted the Indonesian Legal Aid Foundation for help in seeking an apology from Japan or to ask for compensation.(JT 16-1196)

\section{Japanese chemical weapons in China}

Owing to the limited size and capacity of the Japanese 'Ground Self-Defence Force's' chemical unit, Japan considered it impossible to destroy the chemical weapons it left in China at the end of the Second World War in the period of 10 years as prescribed by the Chemical Weapons Convention.

Japan intended to enter negotiations with China on an extension of the period and would make the same request to the supervising body under the Convention. Under the Convention the period for disposal can be extended to 15 years with the approval of the board members and the signatory states. Technically speaking there was no Convention obligation yet for Japan vis-à-vis China since the latter had not yet ratified the Convention, but the two countries had reached an agreement bilaterally on Japan's responsibility for the disposal process. The overall cost of the disposal was expected to run several hundred billion yen.

Japan estimates there are about 700,000 shells containing lethal substances still in China, of which the disposal could be complicated by the age of the shells. China, however, estimates the number at 2 million, and demands that Japan ships them out of China before disposing of them. It claims that left-over Japanese poison had claimed 2,000 victims since the war.(JT 10-11-96)

It was reported in early December 1996 that a group of Chinese filed a suit for damages in the Tokyo District Court against the Japanese government for injuries and deaths caused by Japanese chemical weapons left in China following World War II.(JT 10-12-96) 